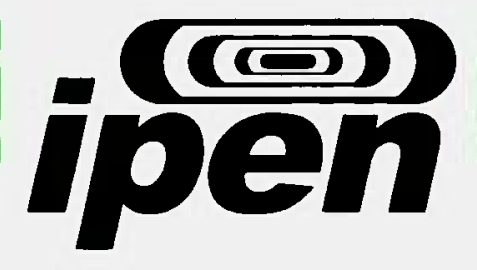

AUTARQUIA ASSOCIADA A UNIVERSIDADE DE SÃO PAULO

\title{
ANÁLISE AMBIENTAL DA CÉLULA A COMBUSTÍVEL DE MEMBRANA TROCADORA DE PROTÓNS SOB O ENFOQUE DA AVALIAÇÃO DO CICLO DE VIDA
}

SANDRA HARUMI FUKUROZAKI

Dissertação apresentada como parte dos requisitos para obtenção do Grau de Mestre em Ciências na Área de Tecnologia Nuclear - Materiais.

Orientadora:

Dra. Emilia Satoshi Miyamaru Seo 


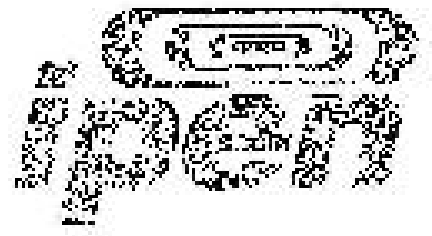

AUTARQUIA ASSOCIADA À UNIVERSIDADE DE SÃO PAULO

ANÁLISE AMBIENTAL DA CÉLULA A COMBUSTÍVEL DE MEMBRANA TROCADORA DE PROTÓNS SOB O ENFOQUE DA AVALIAÇÃO DO CICLO DE VIDA

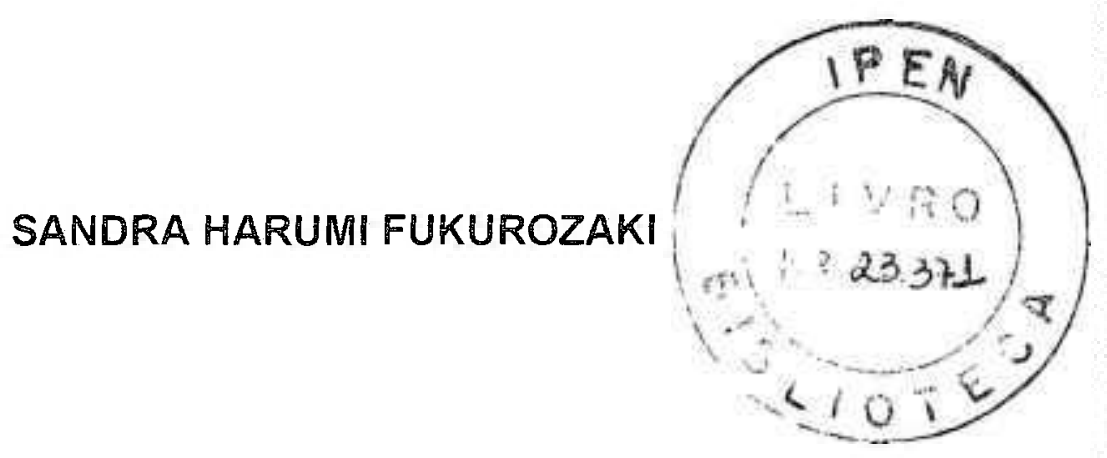

Dissertação apresentada como parte dos requisitos para a obtenção do Grau de Mestre em Ciências na Área de Tecnologia Nuclear - Materiais

Orientadora:

Dra. Emilia Satoshi Miyamaru Seo 


\section{ANÁLISE AMBIENTAL DA CÉLULA A COMBUSTIVEL DE MEMBRANA TROCADORA DE PROTÓNS SOB O ENFOQUE DA AVALIAÇÃO DO CICLO DE VIDA}

\section{SANDRA HARUMI FUKUROZAKI}

Dissertação apresentada como parte dos requisitos para a obtenção do Grau de Mestre em Ciências na Área de Tecnologia Nuclear - Materiais

Orientadora:

Dra. Emília Satoshi Miyamaru Seo 
Aos meus pais e ao Miguel naturalmente. 
Foram várias as instituições e pessoas que colaboraram direta ou indiretamente para a construção deste trabalho, a estas devo meus sinceros agradecimentos.

Ao Conselho Nacional de Pesquisa e Desenvolvimento - CNPq, pela bolsa concedida e ao Instituto de Pesquisas Energéticas e Nucleares - IPEN, pela oportunidade de realização do presente estudo.

À minha família, pelo apoio sempre constante e incondicional ao longo da minha formação, em especial a Monize Kozué Fukurozaki pela paciência nos meus momentos de mau humor e madrugadas acordadas.

À minha orientadora, Dra. Emilia Satoshi Miyamaru Seo, pela amizade, confiança, incentivo e, principalmente, pelos conhecimentos adquiridos no decorrer da nossa convivência.

Aos pesquisadores do Programa de Células a Combustivel - PROCEL, Dr. Marcelo Linardi, Dr. Estevan Spinacé e Dr. Almir Oliveira Neto, pelo suporte, materiais e discussões essenciais para o desenvolvimento desta dissertação.

Aos profissionais da área de Meio Ambiente, pelas críticas e sugestões que serviram de base para a formatação da avaliação ambiental: Dr. Jacques Demajorovic e M.Sc Alcir Vilela Junior - Faculdade de Engenharia Ambiental ICentro Universitário SENAC; Dr. Gil Anderi da Silva - Grupo de Prevenção a Poluição/ Escola Politécnica da Universidade de São Paulo e Dr. Milton Norio Sogabe - Secretaria de Estado do Meio Ambiente (SMA)/ Companhia de Tecnologia e Saneamento Ambiental (CETESB).

Aos doutores e técnicos, pelos esclarecimentos e análises realizadas: Dr. Nelson Batista de Lima, Dra. Mitiko Saiki, Dra. Vera Lúcia Ribeiro Salvador, Dra. Elizabete Dantas Sonoda, Dra. Duclerc Fernandes Parra, Marco Andreoli, Marco Scapin, Olandir Vercino Corrêa e Elias Silveira.

A Dra. Sônia R. M. Castanho, Dr. Egberto Gomes Franco, M.Sc.Edgard Ferrari da Cunha, M.Sc Antônio R. dos Santos, M.Sc Marcelo do Carmo, M.Sc Thais Aranha, M.Sc Martha L. Bejarano, M.Sc Rubens Chiba, M.Sc Walter Kenji, Ilze Puglia, Bruno Ribeiro de Matos, pelo auxílio e informações diversas. Por fim, aos demais colaboradores e colegas de jornada acadêmica do IPEN, pelas idéias e os momentos de distração. 
A nova cultura do desenvolvimento não prevê o retorno à iluminação à vela; projeta-se para o futuro, não para o passado; leva em conta 0 equilíbrio biofísico, não em termos estáticos, mas dinâmicos, avaliando os fatos conforme tempos biológicos, objetivando um fluxo estacionário de energia, de populações, de recursos. 


\section{SANDRA HARUMI FUKUROZAKI}

\section{RESUMO}

A energia é o combustivel do crescimento e um requisito essencial para o desenvolvimento sócio-econômico. No entanto, o atual modelo de produção baseado em combustiveis fósseis é considerado ameaçador para o homem e a natureza. Desta forma, as preocupações relacionadas às atividades antrópicas e os seus efeitos no meio ambiente são traduzidos pela implementação de padrões mais rígidos de controle ambiental e pela mobilização da sociedade em favor das tecnologias energéticas menos impactantes. Diante desse cenário, a Célula a Combustivel de Membrana Trocadora de Prótons - PEMFC tem sido reconhecida como a resposta para a premente necessidade de energia limpa e eficiente. Em relação aos sistemas convencionais de geração de energia, suas vantagens durante o uso a configuram como candidata ideal para diversas aplicações, em especial as móveis. Entretanto, embora o foco de diversas avaliações ambientais em sistemas de energia seja voltado para a etapa da sua utilização, os estágios relacionados à produção do sistema e destinação final devem ser considerados já que estes também apresentam impactos. No caso da PEMFC, nas fases anteriores e posteriores ao uso, os aspectos relacionados aos catalisadores de platina apontam cargas ambientais que não podem ser negligenciadas. Neste sentido, a Avaliação do Ciclo de Vida tem sido utilizada para entender e questionar os riscos e oportunidades que acompanham um determinado produto, a partir de uma visão sistêmica das suas relações com o meio ambiente. É precisamente nesse contexto que o presente trabalho pretende dar sua maior contribuição, a partir de um estudo exploratório almeja-se prover uma análise ambiental dessa tecnologia na etapa pós-uso do conjunto eletrodo membrana, nomeadamente em relação aos catalisadores de platina, sob o enfoque da Avaliação do Ciclo de Vida - ACV. Para atingir tal propósito, são apresentadas e discutidas as relações entre energia, meio ambiente e desenvolvimento, bem como a tecnologia de Células a Combustível e os atuais estudos sobre ACV da PEMFC. As contribuições das questões levantadas foram utilizadas para 0 desenvolvimento de um método de recuperação dos catalisadores da PEMFC e, especialmente, para a sua posterior avaliação ambiental. Dentre os resultados significativos destaca-se a importância da ACV como ferramenta útil para compreender o peso das questões ambientais relacionadàs à platina e, para subsidiar as estratégias relacionadas ao desenvolvimento, consolidação e inovação da PEMFC. 


\title{
ENVIRONMENTAL ANALYSIS OF THE PROTON EXCHANGE MEMBRANE FUEL CELL ON THE SUBJECT OF LIFE CYCLE ASSESSMENT
}

\section{SANDRA HARUMI FUKUROZAKI}

\begin{abstract}
The energy is the fuel of growth and an essential requirement for the socioeconomic development. However, the current production model is based on fossil fuels, considered as threat to man and nature. As for, the relating to the human activities and their effects on the environment, they are handled by the implementation of a more rigid model of environmental control and the mobilization of the society in favor of technologies with less energy impact. In view of this scenario, the Proton Exchange Membrane Fuel Cell - PEMFC has been recognized as a key for the vital need of a clean and efficient energy. Considering the conventional power generation system, their advantages during usage configure its application as an ideal option for several utilities, especially in the mobile sector. Even though, the focus on several environmental evaluations in energy systems is referred back to the initial stage of it use, the employment relating to production of the system and to final destination should be considered, since these also present impacts. In the case of PEMFC, their previous and subsequent phases of use are issues related to the platinum catalysts, which indicates an environmental importance that cannot be overlooked. In this sense, the Life Cycle Assessment has been used to understand and to question the risks and opportunities that are associated to certain product, starting from a systemic concept of their relationships with the environment. It is precisely in this context that the present research intends to present its major contribution, starting from an exploratory study towards the its objectives to provide an environmental analysis of such technology linked to post stage of powder-use of the membrane electrode assembly - MEA, concerning the platinum catalysts, on the subject of Life Cycle Assessment - LCA. To attain such aim, the relationships between energy, environment and development are presented and discussed, as well as, the Fuel Cell technology and the current studies on LCA of PEMFC. Several questions raised up on this issues have contributed in the development of a method of recuperating the PEMFC catalysts and, particularly, for its subsequent environmental evaluation. Among significant results are the importance of LCA, out lined as useful tool for perceiving the weight of environmental matters concerning the platinum and its subsidy strategies relating to the development, consolidation and to the innovation of PEMFC.
\end{abstract}


INTRODUÇÃO

OBJETIVO

\section{FUNDAMENTAÇÃO TÉORICA}

1 - ENERGIA, MEIO AMBIENTE E DESENVOLVIMENTO

1.1 - Energia e Meio Ambiente

1.1.1 - Mudanças Climáticas

1.1.2 - Deposições Ácidas

1.1.3 - Poluição Urbana do Ar 26

1.1 .4 - Centrais Termoelétricas $\quad 27$

1.1 .5 - Centrais Hidroelétricas $\quad 28$

1.1.6 - Centrais Nucleares $\quad 28$

1.2 - Energia e Desenvolvimento 29

2 - Celulas A COMBUStível 31

2.1 - Sonho ou Desafio? 31

2.2 - Origem e História da Tecnologia $3 \mathbf{3 2}$

2.3 - Sistema Conversor de Energia $\quad 34$

2.3.1 - Classificação das Tecnologias $\quad 36$

2.4 - Principais Vantagens $\quad 38$

2.4.1 - Alta Eficiência e Segurança $\quad 38$

2.4.2 - Flexibilidade de Planejamento $\quad 40$

2.4.3 - Desempenho Ambiental $\quad 41$

2.5 - Tecnologia da Célula a Combustível de Membrana Trocadora de Prótons 42

2.5.1 - Evolução Histórica do Desenvolvimento 45

2.5 .2 - Aplicações 46

3 - AVALIAÇÃO DO CICLO DE VIDA 50

3.1 - Breve Histórico e Definições

3.2 - Guia e Marco Metodológico $\mathbf{5 4}$

3.2.1 - Objetivo e Escopo $\quad 55$

3.2.2 - Inventário do Ciclo de Vida - ICV $\quad 57$ 
3.2.3 - Avaliação do Impacto do Ciclo de Vida - AICV

3.2 .4 - Interpretação

3.3 - Avaliação do Ciclo de Vida Simplificada

3.4 - Restrições a Prática da Avaliação do Ciclo de Vida

3.5 - Importância do Uso da Avaliação do Ciclo de Vida

4 - AVAliaçÃo do CiClo de VidA dA CÉlula a COMBustível de MEMBRANA TROCADORA DE PRÓTONS

4 - Emissões Ambientais da SOFC e SPFC: sistema de produção e disposição final

4.1.1 - Sistema PEMFC

4.1.2 - Processo Produtivo do MEA

4.1 .3 - Inventário

72

4.1.4 - Análise do Inventảrio e Considerações sobre o Estudo

4.2 - Avaliação do Ciclo de Vida de Módulos de Células a Combustivel

4.3 - Impactos da Legislação de Resíduos Veiculares na União Européia: opções de fim de vida para as células de eletrólito polimérico 4.5 - Análise Geral dos Estudos sobre a Avaliação do Ciclo de Vida da PEMFC 78

\section{METODOLOGIA}

\section{5 - DESENVOLVIMENTO E ANÁlISE dO PROCESSO DE RECUPERAÇÃO DOS CATALISADORES DE PLATINA DA PEMFC

5.1 - Rota Experimental

5.2 - Avaliação do Ciclo de Vida Simplificada do Processo $\mathbf{8 5}$

5.2 .1 - Objetivo e Escopo

5.2 .2 - Inventário

5.2.2.1 - Análise Termogravimétrica - ATG

5.2.2.2 - Espectrometria de Fluorescência de Raios X - FRX

5.2.2.3 - Difração de Raios X - DRX

5.2.2.4 - Análise por Ativação Neutrônica 
5.2.3 - Avaliação de Impactos

\section{RESULTADOS E DISCUSSÕES}

6 - AVALIAÇÃO dO CICLO DE VIDA DO PROCESSO DE RECUPERAÇÃo DOS CATALISADORES DE PLATINA DA PEMFC

6.1 - Pré Avaliação da ACV: questões relevantes sobre a Platina

6.1.1 - Propriedades gerais da platina

102

6.1.2 - Demanda e Aplicações

104

6.1.3 - Suprimento e Preço

6.1.4 - Impactos Ambientais e Restrições Legais

109

6.1.5 - Considerações sobre a Etapa de Simplificação

6.2 - Inventário: coleta e análise dos dados

6.2.1 - Processo de Produtivo do MEA

6.2.2 - Processo de Recuperação

6.2.3 - Análises de Verificação: eficiência do processo

6.2.4 - Análises de Caracterização: potencial de reciclagem

6.3 - Avaliação de Impactos

6.3.1 - Identificação de Aspectos e Impactos

6.3.2 - Análise da Significância

\section{CONCLUSÕES}

Conclusões

\section{REFERÊNCIAS}


Tabela 1.1 - Escala de problemas ambientais associados à energia

Tabela 1.2 - Contribuição relativa de gases provenientes de combustíveis fósseis ao efeito estufa

Tabela 1.3 - Fontes de poluição e seus poluentes

Tabela 2.1 - Classificação das CaC conforme o eletrólito utilizado

Tabela 3.1 - Exemplos de listas de seleção de categorias de impactos

Tabela 3.2 - Exemplos de indicadores e modelo de caracterização

Tabela 3.3 - Análise dos métodos de simplificação da ACV

Tabela 4.1 - Quantidade dos principais materiais e os requerimentos em termos de energia

Tabela 4.2 - Entrada de energia para cada processo de produção do MEA.

Tabela 4.3 - Perdas de materiais no processo de produção do MEA

Tabela 4.4 - Emissões para o meio ambiente da produção de platina.

Tabela 4.5 - Total de emissões para o meio ambiente na produção do MEA

Tabela 4.6 - Custo das perdas de platina

Tabela 5.1 - Características do MEA

Tabela 5.2 - Exemplo de aspectos e impactos

Tabela 5.3 - Escala de probabilidade

Tabela 5.4 - Escala de severidade

Tabela 5.5 - Escala de limites

Tabela 5.6 - Escala de status regulatório

Tabela 5.7 - Avaliação múltipla dos critérios

Tabela 6.1 - Propriedades da platina

Tabela 6.2 - Estado de oxidação e compostos de platina 
Tabela 6.4 - Suprimento de platina por região em quilogramas

Tabela 6.5 - Custo da fabricação do eletrodo e porcentagem do aumento entre os anos 2004 e 2005

108

Tabela 6.6 - Referências de estudos sobre a concentração de platina em diferentes compartimentos ambientais, na fauna, flora e outros locais

Tabela 6.7 - Composição da tinta catalítica

Tabela 6.8 - Carga catalítica e massa estimada por eletrodo

Tabela 6.9 - Especificações do eletrólito e da camada difusora.

Tabela 6.10 - Valores obtidos na pesagem do MEA e dos seus componentes em gramas

Tabela 6.11 - Comparação entre a massa inicial e final do MEA em gramas

Tabela 6.12 - Comparação entre a massa do eletrólito padrão $(P)$ e do eletrólito obtido no processo em ( $R$ ) em gramas

Tabela 6.13 - Comparação entre a massa da camada difusora padrão e da camada obtida no processo $(R)$ em gramas

Tabela 6.14 - Comparação entre a massa da camada catalítica teorica (T) e a camada obtida no processo em gramas.

Tabela 6.15 - Massa estimada para os elementos da camada catalítica obtida no processo de recuperação em gramas

Tabela 6.16 - Perfil das amostras encaminhadas para análise em gramas

Tabela 6.17 - Determinação da platina e outras impurezas

Tabela 6.18 - Diâmetro médio das partículas de catalisadores de platina preparados por diferentes técnicas

Tabela 6.19 - Identificação de atividades, aspectos e potenciais impactos

Tabela 6.20 - Avaliação da significância dos impactos

Tabela 6.21 - Critérios considerados durante a pontuação 
Figura 1.1 - Efeito estufa

Figura 2.1- Conversão direta de energia das $\mathrm{CaC}$ em comparação as tecnologias de conversão indireta

Figura 2.2 - Classificação das Células a Combustivel

Figura 2.3 - Comparação das eficiências em porcentagem (\%)

Figura 2.4 - Desenho esquemático da PEMFC

Figura 2.5 - MEA e célula unitária da PEFC

Figura 2.6 - Módulo do PEMFC

Figura 2.7 - Exemplo de aplicação portátil (laptop) da PEFC

Figura 2.8 - Veículo de emissão nula - NECAR

Figura 3.1 - Etapas da avaliação do ciclo de vida.

Figura 3.2 - Dimensões do escopo de estudo da ACV

Figura 3.3 - Exemplo de um diagrama de fluxo de um sistema e processos de um produto

Figura 3.4 - Estrutura conceitual da AICV

Figura 3.5 - Procedimentos de simplificação da ACV

Figura 4.1- Diagrama conceitual do ciclo de vida de um sistema CaC em 7 estágios

Figura 4.2 - Diagrama do fluxo de produção do MEA

Figura 5.1- Proposta de recuperação da platina do MEA da PEMFC encontradas na literatura

Figura 5.2 - Diagrama simplificado do procedimento experimental

Figura 5.3 - Software de ACV - Sima Pro Demo

Figura 5.4 - Ficha de coleta de dados

Figura 6.1 - Diagrama geral do ciclo de vida da platina 
Figura 6.2 - Jóia de platina

Figura 6.3 - Platina em barra em grãos

Figura 6.4 - Sensor de platina utilizado para detectar monóxido de carbono 105

Figura 6.5 - Platina ancorada em substrato de alumina, utilizada como catalisador em processos da industria petrolífera

Figura 6.6 - Disco rígido com camada magnética de platina

Figura 6.7 - Preço da platina no período de janeiro de 2004 a dezembro de 2005

Figura 6.8 - Escala de risco ecológico

Figura 6.9 - Ciclo de vida da platina na PEMFC

Figura 6.10 - Diagrama de blocos de preparação do MEA

Figura 6.11 - Inventário do processo de recuperação

Figura 6.12 - Curva da ATG para a massa catalitica

Figura 6.13 - Curva da ATG para tinta catalítica

Figura 6.14 - Curva da ATG para a platina comercial

Figura 6.15 - Elementos detectados pela análise de ativação neutrônica

Figura 6.16 - Difratogramas de raios X para a camada catalítica

Figura 6.17 - Difratogramas de raios $X$ para a tinta catalítica

Figura 6.18 - Difratogramas de raios $X$ para a platina comercial

Figura 6.19 - Voltamogramas cíclicos para a massa catalítica, tinta e platina comercial

Figura 6.20 - Atividades do processo de recuperação nas quais são identificados os aspectos ambientais

Figura 6.21 - Exemplo de uma cadeia de efeitos relativos ao consumo de energia 
No decorrer do tempo, a produção de energia elétrica constituiu-se como um fator chave no desenvolvimento das sociedades. A partir da I Revolução Industrial, em meados do século XVIII, uma transformação indubitável ocorreu nas relações produtivas e sociais, favorecida pela descoberta de novos mecanismos de conversão energética e fomentada pelo uso do carvão. A substituição gradativa dessa fonte por outras, como o petróleo e o gás natural, propiciou uma nova organização de âmbito global, concomitamente a II Revolução Industrial, sobrevinda um século depois.

Desenvolveu-se então toda uma gama de indústrias baseadas na economia de energia fóssil, por um lado, voltadas para a produção e suprimento de energia: máquinas diversas, turbinas, sistemas de transmissão; por outro, para a sua utilização: equipamentos de uso industrial e doméstico, iluminação, força motriz, climatização e comunicação. Conseqüentemente, esse conjunto de instrumentos alterou de forma profunda o ritmo e o curso dos processos de formação sócio-espacial e econômicas da humanidade, moldando as caracteristicas do atual desenvolvimento.

Contudo, nos anos $70^{1}$, uma crise mundial sem precedentes, acarretada pelo boicote internacional realizado pelas nações árabes, membros da Organização dos Países Exportadores de Petróleo - OPEP, propiciou uma busca frenética por fontes alternativas de energia e despertou o mundo para a necessidade de melhor utilização dos recursos naturais. No mesmo período, internacionalmente, assistia-se ao surgimento de uma economia ambiental, como conseqüência da inquietação global quanto a sustentabilidade dos sistemas de produção vigente.

Pelo prisma do crescimento econômico, formularam-se conceitos como Integrated Resources Planning e o Demand Side Management, voltados para o planejamento e uso racional dos recursos, os quais ainda hoje constituem modos de gestão e expansão de sistemas energéticos, como alternativa ao paradigma meramente demográfico de oferta crescente para consumo crescente (GRIMONI et. al., 2004).

\footnotetext{
'Em 1973 a crise do petróleo foi provocada pelo embargo ao fornecimento de petróleo aos Estados Unidos e às potencias européias e posteriormente. em 1979, causada pela revolıção iraniana que derruba o xá Reza Pahlevi.
} 
Do ponto de vista ecológico, os desastres ambientais fatais como o fog em Londres, a contaminação por mercúrio na baía de Minamata no Japão, o acidente nuclear em Three Mile Island nos Estados Unidos, a contaminação por gases tóxicos em Bhopal na Índia, bem como as conseqüências locais, regionais e globais associadas ao uso intensivo de combustiveis fósseis, como chuva ácida, camada de ozônio e aumento da temperatura (PENNA, 1999), indicaram a insustentabilidade do modelo energético corrente e a necessidade de fomentar o desenvolvimento de sistemas geradores de energia que possibilitassem uma contribuição decisiva para um futuro ambientalmente seguro.

Paralelamente, o pensamento inaugurado pelo Clube de Roma (1960), prosseguido pela Conferência de Estocolmo (1972), o Relatório da Comissão de Brundtiand (1987) e a Reunião da Cúpula da Terra (1992) conduziram a conclusões similares, segundo os quais o modelo de produção e consumo em vigor, incluindo o atendimento as exigências energéticas, não é compativel com uma perspectiva de sustentabilidade intergerencial e nem equidade, em âmbito mundial no presente.

Estas constatações resultaram no paradigma do desenvolvimento sustentável, no qual a capacidade de assegurar os direitos das gerações presentes e futuras estão intimamente relacionadas à energia (REIS \& SILVEIRA, 2001). Não obstante, também emergiu a crescente tendência de padrões mais rígidos de controle ambiental a valorização das fontes renováveis, menos poluidoras $e$, os instrumentos de prevenção e mitigação das externalidades ambientais negativas, sobretudo os que visam auxiliar na compreensão, redução e controle dos impactos na natureza, entre os quais ressalta-se a Avaliação do Ciclo de Vida - ACV.

Dentre as diferentes rotas inovadoras para a geração de energia mais sustentável está, atualmente, o hidrogênio, cuja viabilidade energética encontrase na tecnologia de células a combustivel - CaC. Estas são dispositivos eletroquímicos que podem converter continuamente a energia química de certas fontes renováveis ou não, em eletricidade sem a necessidade de combustão a quente e com um rendimento global superior aos equipamentos de transformação convencionais. Em adição a natureza eletroquimica da reação produzindo água 
(KORDESCH \& SIMADER, 1996), a alta eficiência pode propiciar uma significativa redução do uso de combustiveis fósseis e da liberação de gases do efeito estufa, resultando em emissões locais extremamente baixas durante o uso, fator especialmente importante em áreas densamente povoadas.

Deste modo, os diferentes tipos de tecnologia $\mathrm{CaC}$ configuram-se em candidatas ideais para uso em aplicações móveis e estacionárias, incluindo pequenas residências, plantas de energia e calor de média e larga escala, respectivamente. No setor móvel, as $\mathrm{CaC}$, particularmente as de baixa temperatura de operação $\left(80\right.$ a $90{ }^{\circ} \mathrm{C}$ ), como a Célula a Combustível de Membrana Trocadora de Prótons - PEMFC, podem ser usadas em veículos particulares e coletivos, trens, aviões, barcos, além de sistemas portáteis de diversos usos (BAUEN et. al., 2003).

Perante essas particularidades, os distintos setores da sociedade têm direcionado uma maior atenção para as $\mathrm{CaC}$, principalmente em relação a PEMFC, visto a crescente demanda por energia e a preocupação em relação à qualidade urbana do ar, acidificação regional e mudanças climáticas. Entretanto, essas características vinculadas à utilização da tecnologia refletem apenas parte deste quadro, pois recursos são consumidos e emissões são geradas em outras etapas do contexto global do ciclo de vida desse produto, incluindo a manufatura e a disposição final.

Segundo KARAKOUSSIS et. al (2000), o estágio em uso é tipicamente dominante na avaliação de todo o ciclo de vida dos sistemas convencionais de geração de energia e engenharia de transporte. Contudo, os sistemas de $\mathrm{CaC}$ comprometem uma escala relativamente exótica de materiais e requerem processos de manufatura que ainda estão em desenvolvimento, conseqüentemente a análise dos seus outros estágios do ciclo de vida são de suma importância, visto apresentarem vantagens ambientais durante sua utilização.

No caso da PEMFC, mesmo encontrando-se no limiar do estágio comercial, o fator determinante para a sua ampla inserção no mercado envolve, além de questões econômicas relacionadas ao alto custo dos materiais da membrana e dos catalisadores de platina, os aspectos ambientais relacionados a este metal 
durante a fase de produção e pós-consumo do módulo da PEMFC (PEHNT, 2001; HANDLEY, 2002).

Neste sentido, a Avaliação do Ciclo de Vida tem se consolidado como uma ferramenta líder, tanto no mundo empresarial como governamental, para entender e questionar os riscos e oportunidades que acompanham os produtos ao longo de sua vida, desde a fase de extração de recursos para a manufatura até o seu destino final, pós-consumidor.

Por conseguinte, os processos de decisão baseados em uma ACV conduzem a ações mais efetivas e, com maior sustentação no longo prazo com relação à redução dos custos econômicos e ambientais das companhias e para o país (CALDEIRA-PIRES et. al, 2005). Portanto, para o desenvolvimento e promoção de novos modelos energéticos, torna-se imperativo a adoção desse instrumento.

Face às considerações acima, a preocupação primordial deste estudo está em convergência com o momento atual, isto é, na necessidade de aprofundar o conhecimento relacionado ao peso das questões ambientais no desenvolvimento, consolidação e inovação da Célula a Combustivel de Membrana Polimérica Trocadora de Prótons - PEMFC, visto, no âmbito do desenvolvimento sustentável, a premência pelo fornecimento de energia limpa e segura ao meio ambiente. 
Tendo em vista as considerações apresentadas na introdução e principalmente, dada a importância dos catalisadores de platina no âmbito econômico e ambiental de desenvolvimento da Célula a Combustivel de Membrana Trocadora de Prótons - PEMFC, o presente trabalho tem por objetivo geral prover uma análise ambiental dessa tecnologia na etapa pós-uso do conjunto eletrodo membrana, nomeadamente em relação à platina, sob o enfoque da Avaliação do Ciclo de Vida - ACV. Neste sentido, os seguintes objetivos específicos foram delimitados:

1)- Apresentar os aspectos gerais sobre energia, sua relação com o meio ambiente e desenvolvimento sustentável, bem como a tecnologia PEMFC;

2)- Proporcionar informações sobre a abordagem metodológica da Avaliação do Ciclo de Vida e sua importância no contexto do estudo;

3)- Analisar e discutir as principais publicações existentes sobre a ACV da PEMFC, especificamente no que tange as questões relacionadas aos eletrocatalisadores de platina;

4)- Desenvolver um método de recuperação de platina e exemplificar o uso da $A C V$, avaliando a sua funcionalidade na definição de métodos para a recuperação e reciclagem do catalisador da PEMFC, a partir de um estudo exploratório.

Para atingir tal propósito, o desenvolvimento da pesquisa consistiu inicialmente na pesquisa bibliográfica em base de dados especializados. Esta etapa consolidou-se na construção de quatro capítulos nos quais são apresentadas as fundamentações teóricas do estudo que serviram de alicerce para o desenvolvimento do método de recuperação dos catalisadores de platina da PEMFC e, especialmente, para a sua posterior avaliação ambiental.

Os procedimentos realizados na construção e avaliação do processo configuraram na metodologia aqui apresentada como quinto capitulo, sendo os dois últimos capítulos subseqüentes os resultados e discussões e, as conclusões da pesquisa. Portanto, o trabalho está estruturado da seguinte forma: 
O capítulo I apresenta concisamente os aspectos relevantes sobre energia, meio ambiente e desenvolvimento, cujo contexto aborda a importância da tecnologia de $\mathrm{CaC}$ no cenário atual. Na seqüência, o capitulo II aglutina informações sobre a CaC, apontando sua origem, histórico do desenvolvimento, suas principais características e vantagens, com especial atenção à tecnologia PEMFC, inserindo as questões relevantes para a abordagem metodológica da ACV.

Subseqüentemente, o capitulo III introduz a Avaliação do Ciclo apresentando o histórico, guia e marco metodológico, simplificação da ACV e outros aspectos como importância do uso dessa ferramenta de gestão no desenvolvimento industrial e no Brasil.

O capitulo IV aglutina informações sobre os atuais estudos realizados sobre a Avaliação do Ciclo de Vida da PEFC e, dada a ausência de literatura nacional sobre o assunto, optou-se por descrever e discutir três dos principais estudos realizados internacionalmente, identificando os problemas ambientais associados ao ciclo de vida de um módulo da PEFC e, ainda, suas implicações para a sustentabilidade da tecnologia.

No capítulo $V$ apresenta-se o desenvolvimento e a análise do processo de recuperação da platina da PEMFC em duas etapas. A primeira caracteriza-se pela descrição dos procedimentos utilizados na rota experimental, enquanto a segunda trata daqueles relacionados à análise simplificada da ACV dos MEA da PEFC, produzida e utilizada no Programa de Pesquisa e Desenvolvimento de Células a Combustivel do IPEN (PROCEL).

O capítulo VI traz os resultados e discussões decorrentes da avaliação do ciclo de vida simplificada. No entanto, dada as dificuldades notórias e grande divergência no tratamento das questões levantadas, este capítulo se coloca como uma contribuição e discussão no sentido de criar abordagens ou métodos que incluem as questões ambientais sistematicamente na pesquisa e desenvolvimento da tecnologia PEFC. Por fim, as principais constatações da pesquisa, incluindo as recomendações e as sugestões futuras sobre as questões tratadas neste estudo são apresentadas nas conclusões. 


\section{1 - ENERGIA, MEIO AMBIENTE E DESENVOLVIMENTO}

A história do desenvolvimento humano possui uma estreita relação com o uso da energia, cuja participação imprimiu e imprime, o ritmo das modificações no contexto sócio-econômico. A partir da segunda metade do século XVIII, a referência ao uso intensivo das fontes energéticas, em termos produtivos, pode ser verificada na Europa Ocidental, particularmente durante a Revolução Industrial.

Neste periodo, o apogeu das máquinas a vapor elege o carvão mineral como fonte de energia primária, devido às suas características e quantidade disponivel, superando assim, o uso da lenha. Na segunda metade do século XIX, a indústria do petróleo dava seus primeiros passos na participação da matriz energética mundial, inicialmente em solo norte-americano (até meados da Primeira Guerra Mundial) e, posteriormente no Oriente Médio, consolidando os paises desta região em uma das principais fontes de energia no mundo.

Paralelamente, a energia com qualidade, de fácil acesso, com alto grau de fracionamento se desenvolve no final do século XIX, marcando o surgimento da indústria da eletricidade. Tratando-se de uma fonte secundária de energia (depende de transformações a partir de fontes primárias), a eletricidade destacouse ao longo do século $X X$ face à sua participação na viabilização de atividades $e$ processos, desde os primórdios da iluminação pública até os atuais equipamentos eletrônicos, em especial os motores elétricos.

O motor elétrico trifásico representou um importante passo no sistema energético, estabelecendo estruturas e conceitos que evoluíram e prevalecem até os dias de hoje. Para a indústria, o uso da eletricidade, significou a possibilidade de concepção de layout's adequados de forma independente aos processos produtivos (FERNANDES FILHO et. al, 2004). Quanto à sociedade, o acesso à eletricidade proporcionou, além de bens de consumo e serviços necessários à qualidade de vida, o desenvolvimento social no seu sentido mais amplo.

Não obstante, o surgimento de novas tecnologias também propicia, a partir dos anos 50, o uso da energia nuclear, na qual acreditava-se na época que esta 
viria a substituir a economia de energia fóssil. De acordo com UDAETA et. al (2004), nos tempos modernos, as energias renováveis se consolidaram apenas por meio de grandes hidroelétricas. No entanto, a primeira grande crise do petróleo em 1973, desperta o desenvolvimento de novos mecanismos de conversão de energia baseada em recursos renováveis e, a busca pela garantia de atendimento às necessidades futuras.

Desta forma, ao longo do tempo foram várias as fontes energéticas que participaram no cotidiano das populações, umas sucedendo às outras, ou ainda, atuando simultaneamente, em proporções variadas, conforme a sua disponibilidade e custo. Todavia, o uso da energia em equilibrio com o desenvolvimento sócio-econômico representa um dos grandes desafios da humanidade. Para tanto torna-se importante ter uma compreensão minimamente clara dos processos envolvidos nas transformações energéticas e suas conseqüências ambientais.

\subsection{Energia e Meio Ambiente}

No decorrer da sua história, a humanidade tem selecionado os sistemas energéticos em função de dois elementos: a disponibilidade técnica e a viabilidade econômica. Porém, o modelo energético vigente tem se revelado insustentável, comprometendo, cada vez mais a curto prazo, os equilibrios ecológicos e climáticos e, conseqüentemente o desenvolvimento sócio-econômico e o bem estar social. Desta forma, na última década, um novo parâmetro tem progressivamente condicionado a aceitação ou recusa dos sistemas de energia: os impactos ambientais resultantes da sua implementação.

Conforme OLIVEIRA et. al (2004) o setor energético produz efeitos nocivos ao meio ambiente em toda a sua cadeia de desenvolvimento, desde a extração de recursos naturais até os seus usos finais. Por exemplo, a extração de recursos energéticos, seja petróleo, carvão, biomassa ou hidroeletricidade, têm implicações em mudanças nos padrões de uso do solo, recursos hídricos, alteração da cobertura vegetal e na composição atmosférica. 
Já os processos relacionados com a produção e uso de energia liberam para a atmosfera, a água e o solo diversas substâncias que comprometem a saúde e sobrevivência não só do homem, mas também da fauna e flora. Embora seja difícil identificar com clareza todos esses impactos, uma vez que estes podem ocorrer de forma direta e indiretamente, a energia, do ponto de vista global, pode ser apontada como uma das principais fontes de desequilíbrio da natureza causada pelo homem.

Não obstante, os danos ambientais não se restringem ao local onde se realizam as atividades de produção ou de consumo de energia, mas também abrangem as escalas regionais e globais (TAB 1.1). No nivel regional pode-se mencionar, por exemplo, o problema de precipitações ácidas, ou ainda o derramamento de petróleo em oceanos, que pode atingir vastas áreas.

TABELA 1.1 - Escala de problemas ambientais associados à energia

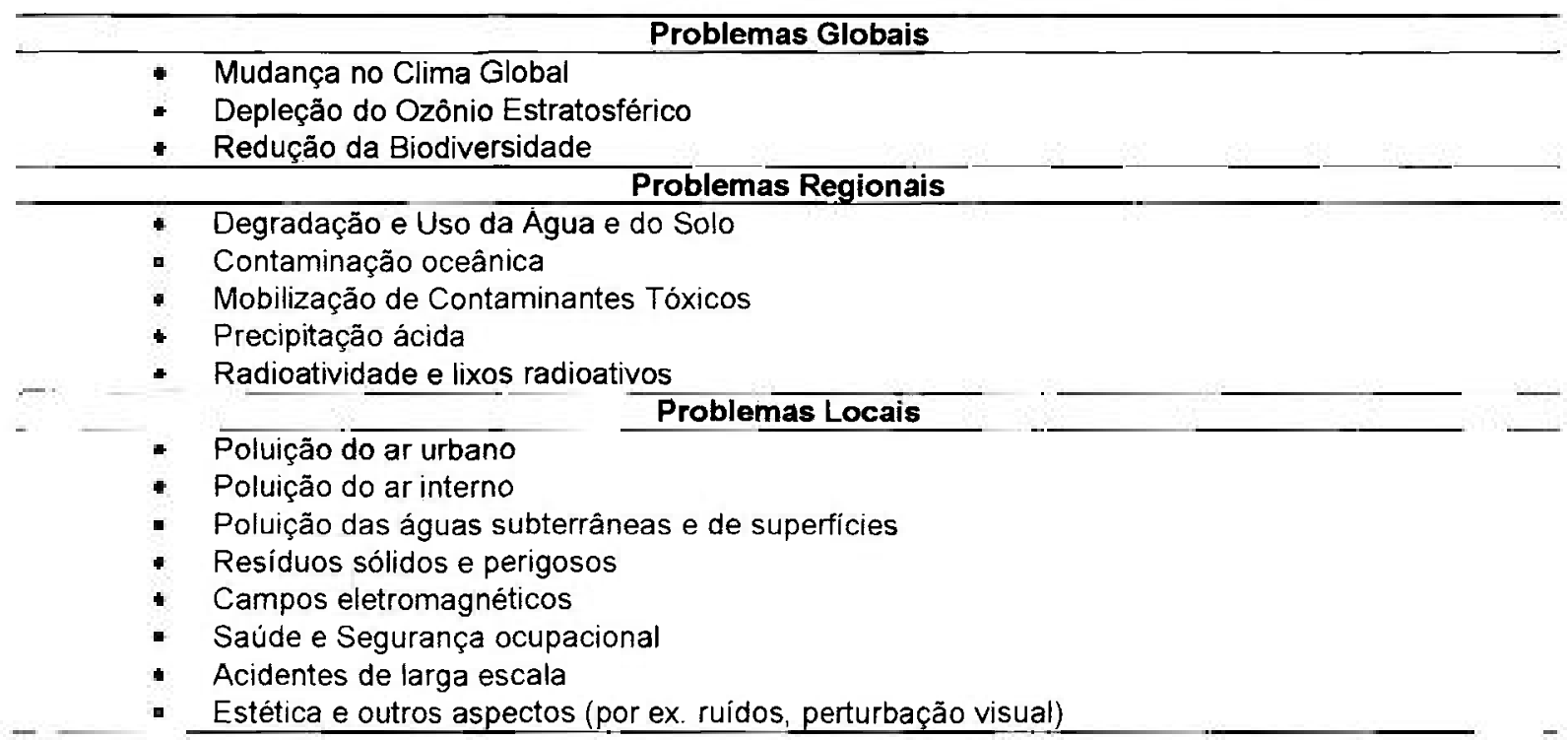

Fonte : CARVALHO (2000)

Em relação aos impactos globais, e os exemplos mais contundentes são as alterações climáticas resultantes do acúmulo de gases na atmosfera (efeito estufa) e, a depleção da camada de ozônio devido ao uso de clorofluorcarbonetos utilizados em equipamentos de ar condicionado e refrigeradores. Neste sentido, apresenta-se a seguir a principal conseqüência ambiental de cada escala de 
abrangência, e posteriormente os impactos derivados dos atuais sistemas de energia.

\subsubsection{Mudancas Climáticas}

Um dos mais complexos e maiores efeitos das emissões do setor energético são os problemas globais relacionados a mudanças climáticas. Segundo REIS et. al (2005), o aquecimento global resulta da modificação na intensidade de radiação térmica emitida pela superfície da Terra, em função da crescente concentração de gases do efeito estufa (GEE), cujas emissões estão relacionadas ao uso de combustiveis fósseis (TAB .1.2).

TABELA 1.2 - Contribuição relativa de gases provenientes de combustíveis fósseis ao efeito estufa

\begin{tabular}{|c|c|c|c|c|c|c|}
\hline & $\begin{array}{l}\text { Gás Carbónico } \\
\left(\mathrm{CO}_{2}\right)\end{array}$ & Metano $\left(\mathrm{CH}_{4}\right)$ & $\begin{array}{c}\text { Oxido Nitroso } \\
\left(\mathrm{N}_{2} \mathrm{O}\right)\end{array}$ & $\begin{array}{l}\text { Clorofluor- } \\
\text { carbonetos } \\
\text { (CFCs) }\end{array}$ & Ozônio $\left(\mathrm{O}_{3}\right)$ & $\begin{array}{l}\text { Monoxido de } \\
\text { Carbono (CO) }\end{array}$ \\
\hline $\begin{array}{l}\text { Principal fonte } \\
\text { e atividade }\end{array}$ & $\begin{array}{l}\text { Combustiveis } \\
\text { fósseis, } \\
\text { desmatamento }\end{array}$ & $\begin{array}{l}\text { Combustiveis } \\
\text { fósseis, queima } \\
\text { de biomassa }\end{array}$ & $\begin{array}{l}\text { Combustiveis } \\
\text { fósseis, queima } \\
\text { de biomassa }\end{array}$ & $\begin{array}{c}\text { Refrigeradores, } \\
\text { aerossóis, } \\
\text { processos } \\
\text { industriais }\end{array}$ & $\begin{array}{l}\text { Hidrocarboneto } \\
\text { (com Nox) } \\
\text { queima de } \\
\text { biomassa }\end{array}$ & $\begin{array}{l}\text { Combustiveis } \\
\text { fósseis, queima } \\
\text { de biomassa }\end{array}$ \\
\hline $\begin{array}{l}\text { Tempo de vida } \\
\text { na atmosfera }\end{array}$ & $50-200$ anos & 10 anos & 150 anos & $60-100$ anos & $\begin{array}{l}\text { Semanas e } \\
\text { meses }\end{array}$ & Meses \\
\hline $\begin{array}{l}\text { Taxa anual de } \\
\text { aumento }\end{array}$ & $0,5 \%$ & $0.9 \%$ & $0,3 \%$ & $4 \%$ & $0,5-2.0 \%$ & $0,7-1,05$ \\
\hline $\begin{array}{l}\text { Contribuição } \\
\text { relativa ao } \\
\text { efeito estufa } \\
\text { antropico }\end{array}$ & $60 \%$ & $15 \%$ & $5 \%$ & $12 \%$ & 5s: & . \\
\hline
\end{tabular}

Fonte: COTTON \& PIELKE (1995) modificado por FUKUROZAKI (2006)

Conforme JANUZZI (2004), o acúmulo de gases, como o dióxido de carbono na atmosfera, acentua o efeito estufa natural do ecossistema terrestre (FIG. 1.1) a ponto de romper os padrões de clima que condicionaram a vida humana, de animais, peixes, agricultura, vegetação, entre outros. 


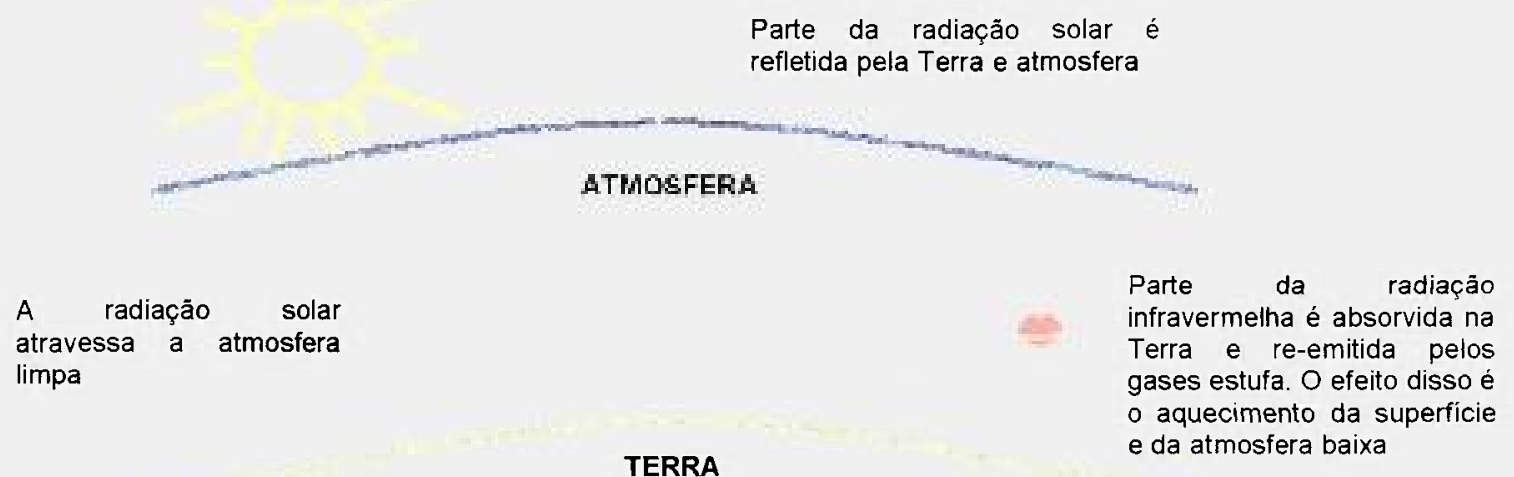

A maior parte da radiação solar é absorvida pela superficie da Terra, aquecendo-a
A superficie da Terra, emite radiaçāo infravermelha

FIGURA 1.1 - Efeito estufa

Fonte: CARVALHO, 2000

Neste sentido, as implicações no clima mundial para os paises e suas populações encontram-se na alteração da produtividade agrícola e da pesca, inundações de regiões costeiras e aumento de desastres naturais. A seriedade desses efeitos tem sido reconhecida por diversos estudos científicos internacionais e vários paises estão procurando consenso para uma agenda mínima de atividades para controle e mitigação de emissões, como o Protocolo de Kyoto, discutido no âmbito dos países signatários da Convenção Climática .

\subsubsection{Deposicões Ácidas}

Embora o termo chuva ácida seja amplamente utilizado nas publicações sobre o assunto em questão, de acordo com OLIVEIRA et. al (2004), a denominação mais adequada para o fenômeno é precipitações ácidas, visto que as deposições podem ocorrer em forma de chuva, neve, partículas sólidas ou gases.

Os principais componentes encontrados nas precipitações ácidas são o ácido sulfúrico $\left(\mathrm{H}_{2} \mathrm{SO}_{4}\right)$ e o ácido nítrico $\left(\mathrm{HNO}_{3}\right)$, formados na atmosfera a partir 
do dióxido de enxofre $\left(\mathrm{SO}_{2}\right)$ e dos óxidos de nitrogênio $\left(\mathrm{NO}_{\mathrm{x}}\right)$, ambos produtos daqueima de combustíveis fósseis. Os danos causados pelos ácidos liberados no uso desse energético, precipitados tanto na sua forma seca quanto úmida, prejudicam a cobertura de solos, vegetação, agricultura e materiais manufaturados.

No que tange a saúde humana, a presença de particulados contendo $\mathrm{SO}_{2} \mathrm{e}$ $\mathrm{NO}_{x}$ provocam ou agravam doenças respiratórias como bronquite e enfisema, especialmente em crianças. Esse tipo de problema tem sido verificado em regiões da China, Hong Kong e Canadá que sofrem os efeitos de termoelétricas a carvão situadas muitas vezes em locais distantes de onde ocorrem às precipitações ácidas.

\subsubsection{Poluicão Urbana do Ar}

Um dos problemas mais antigos da civilização é a poluição urbana do ar, sendo responsável por inúmeras doenças, inclusive mortalidade nas populações das grandes cidades. A principal fonte de poluição em áreas urbanas advém da queima de combustiveis fósseis para fins de aquecimento doméstico, geração de energia, funcionamento de motores a combustão interna, processos industriais e incineração de resíduos sólidos (TAB 1.3).

TABELA 1.3 - Fontes de poluição e seus poluentes
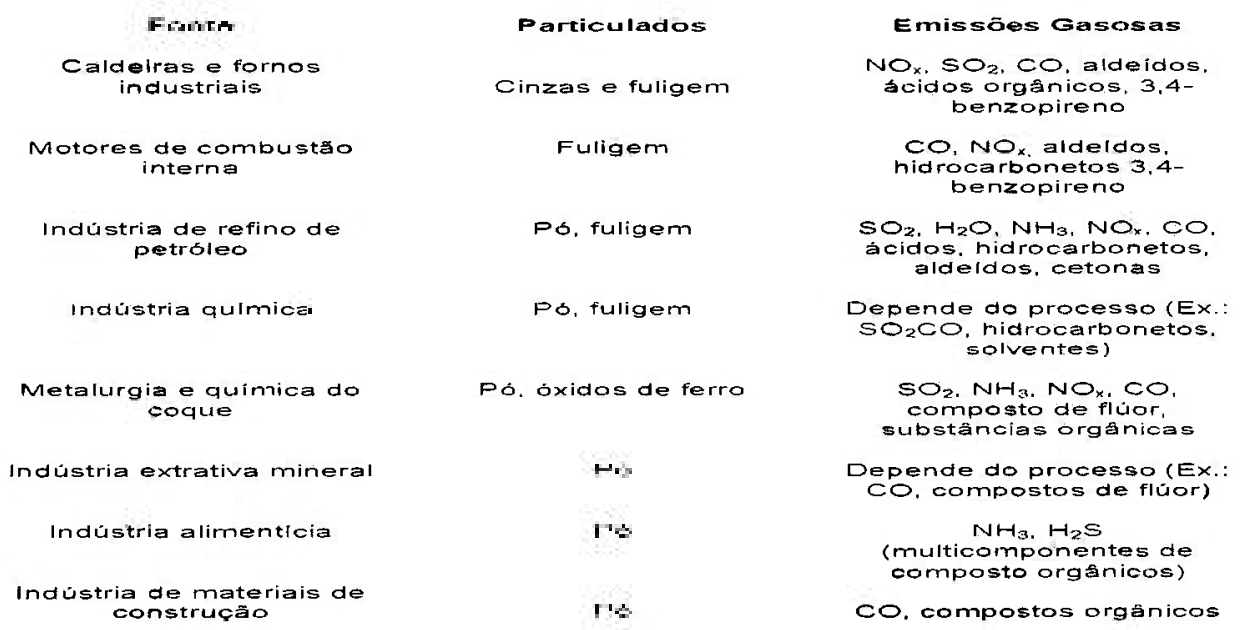

Fonte: Conservação de Energia - Eficiência Energética de Instalação e Equipamentos, 2001 apud CARVALHO (2000) 
O consumo de derivados de petróleo pelo setor de transporte é o que apresenta a maior contribuição para a degradação do meio ambiente no nível local. Estima-se que $50 \%$ dos hidrocarbonetos emitidos em áreas urbanas e aproximadamente $25 \%$ do total das emissões de todo dióxido de carbono gerado no mundo, resultem das atividades desenvolvidas com os sistemas de transporte.

Ademais, a baixa qualidade desses combustiveis em muitos paises, aliada à precariedade de veículos, trânsito congestionado e condições climáticas desfavoráveis em grandes cidades, contribuem para que exista uma quase permanente concentração de finas partículas no ambiente urbano, que comprometem significativamente a qualidade do ar e, desta forma, a saúde humana (GRIMONI et. al, 2004).

\subsubsection{Centrais Termoelétricas}

A produção de eletricidade em termoelétricas representa em escala mundial cerca de um terço das emissões antropogênicas de dióxido de carbono, sendo seguida pelas emissões do setor de transporte e industrial. Os principais combustiveis utilizados em todo o mundo são o carvão, derivados de petróleo $e$, crescentemente, o gás natural. Existem ainda outros tipos de usinas termoelétricas que queimam resíduos de biomassa (lenha, bagaço) e até mesmo resíduo urbano.

Além das emissões de gases e partículas, ocorrem outros problemas associados com utilização de água para o processo de geração termoelétrica, pois muitas centrais usam a água para refrigeração ou para produção de vapor. Esse tem sido um dos principais obstáculos para a implantação de termoelétricas no país, uma vez que diversos projetos se localizam ao longo do principal gasoduto construído, seguindo exatamente as bacias hidrográficas com problemas de abastecimento e de qualidade de água em regiões densamente povoadas (JANUZZI, 2004).

É importante notar também que houve bastante progresso com relação ao aumento da eficiência de usinas termoelétricas pela introdução de tecnologias de co-geração e turbinas a gás. As possibilidades de gaseificação de carvão, 
madeira e bagaço oferecem novas oportunidades de usinas mais eficientes e com menores impactos em relação às convencionais.

\subsubsection{Centrais Hidroelétricas}

Segundo JANUZZI (2004), muitas vezes faz-se referência à hidroeletricidade como sendo uma fonte "limpa" e de pouco impacto ambiental. $\mathrm{Na}$ entanto, embora a construção de reservatórios (grandes ou pequenos) tenha resultado em enormes benefícios para o país, ajudando a regularizar as cheias, promover irrigação e navegabilidade de rios, também produziram impactos irreversiveis ao meio ambiente;

No caso de grandes reservatórios, existem problemas com mudanças na composição e propriedades químicas da água, alteração na temperatura, concentração de sedimentos, e outras modificações que ocasionam problemas para a manutenção de ecossistemas à jusante da localização da barragem além, daqueles relacionados ao reassentamento de populações locais. Esses empreendimentos, ainda que bem controlados, têm promovido impactos na diversidade de espécies (fauna e flora) e na densidade das populações de peixes.

No Brasil, um dos maiores exemplos é o caso da hidroelétrica de Balbina, que provocou a inundação de parte da floresta nativa, ocasionando alterações na composição e acidez da água, nas quais posteriormente teve impacto no próprio desempenho da usina. Até recentemente as turbinas apresentavam problemas de corrosão e depósito de material orgânico, em função das modificações que ocorreram na composição da água.

\subsubsection{Centrais Nucleares}

A energia nuclear é talvez aquela que mais tem chamado atenção quanto aos seus impactos ao meio ambiente e à saúde humana. São três os principais problemas ambientais dessa fonte de energia. O primeiro é a manipulação de material radioativo no processo de produção de combustível nuclear e nos reatores nucleares, com riscos de vazamentos e acidentes. $O$ segundo está 
relacionado com a possibilidade de desvios clandestinos de material para utilização em armamentos e conseqüentemente, acentuando riscos de associados ao uso de energia nuclear (JANUZZI, 2004).

Finalmente, o último relaciona ao armazenamento dos rejeitos radioativos das usinas. Embora, tenha ocorrido substancial progresso no desenvolvimento de tecnologias que diminuem praticamente os riscos de contaminação radiativa por acidente com reatores nucleares, aumentando consideravelmente o seu nivel de segurança, ainda não se apresentam soluções satisfatórias e aceitáveis para o problema do resíduo nuclear (ibidem, 2004).

Desta forma, os desafios para continuar a expandir as necessidades energéticas da sociedade com menores efeitos ambientais são enormes, o que implica na premência de significativas mudanças nas estratégias de desenvolvimento, nas tecnologias em vigor, bem como nos padrões de consumo da sociedade moderna, antes que esses efeitos nocivos aqui mencionados atinjam um ponto irreversivel.

\subsection{Energia e Desenvolvimento}

Os valores que sustentam o atual modelo de desenvolvimento na sociedade estruturam-se na exagerada ênfase do progresso econômico, no qual freqüentemente encontra-se a exploração descontrolada dos recursos naturais, uso de tecnologias de larga escala e consumo desenfreado, responsáveis pela degradação ambiental, disparidades econômicas, desintegração social e, entre outros, na falta de perspectivas futuras.

Diante deste quadro, no caminho para atingir um desenvolvimento sustentável, a questão energética tem um significado bastante relevante, à medida que os vários desastres ecológicos e humanos das últimas décadas têm relação intima com a produção de energia e, o fornecimento eficiente é considerado uma das condições básicas para o desenvolvimento sócioeconômico (SILVEIRA et. al, . 2001).

De acordo com o Relatório da Comissão de Brundtland, o desenvolvimento sustentável responde à necessidade do presente sem comprometer a capacidade 
das gerações futuras de satisfazer às suas próprias. Tal conceito agrega em sua definição, três pontos fundamentais: crescimento econômico, equidade social e equilíbrio ecológico (DONAIRE, 1995).

Concretamente, este novo paradigma apóia-se nos modos de produção e consumo viáveis a longo prazo para o meio ambiente, associados ao fornecimento de serviços e produtos que atendem as necessidades básicas da população e proporcionem melhor qualidade de vida, além, dentre outros aspectos, à minimização do uso dos recursos naturais.

Neste contexto, sendo a produção de eletricidade responsável por aproximadamente um terço do consumo de energia primária mundial e com tendências a expandir nas próximas décadas ficam evidentes a necessidade de profundas mudanças na geração, distribuição e uso da energia. Trata-se de transformações em direção a um maior uso de recursos renováveis e um afastamento gradual dos combustíveis fósseis.

Para tanto, os esforços de inovação tecnológica na área energética para um futuro com menos impactos ambientais são imprescindíveis, pois o fomento das energias renováveis poderá, por ventura, constituir-se na chave para um desenvolvimento sustentável, nomeadamente para cumprir as políticas de preservação do meio ambiente e, em particular para travar as alterações climáticas.

Nesta perspectiva e em meio as diferentes rotas tecnológicas, as células a combustivel ( $\mathrm{CaC}$ ) têm sido identificadas como parte da resposta para a premente necessidade mundial de energia limpa e eficiente. Esta tecnologia de geração de eletricidade, também reconhecida como um componente fundamental para a futura "Economia do Hidrogênio" poderá reduzir substancialmente emissões de gases do efeito estufa, associados ao atual sistema de transporte e produção de energia (PEHNT \& RAMESOHI, 2002). 


\section{2- CÉLULAS A COMBUSTIVEL}

\section{1 - Sonho ou Desafio?}

As duas últimas décadas do século $X X$ podem ser consideradas como a transição dos métodos de produção de energia, armazenamento e conversão. Os combustiveis fósseis - o carvão, o óleo e o gás natural, responsáveis pelo inacreditável desenvolvimento da tecnologia do mundo ocidental e sua crescente mobilidade de produção são considerados ameaçadores para a sobrevivência do ambiente natural como conhecemos hoje.

Simultaneamente, também se manifesta neste cenário à preocupação quanto ao consumo irracional e conseqüente desaparecimento de combustiveis fósseis, criando barreiras para o futuro do progresso tecnológico, no mesmo período em que a crescente população mundial precisa de mais alimento, melhores moradias, aperfeiçoamento de produtos industriais e expansão dos meios de comunicação e transporte.

Soma-se ainda, o dilema causado pela realização prévia do conceito de que a energia ilimitada, disponivel pela geração de energia nuclear, contenha propósitos perigosos. Não obstante, esse quadro tem se agravado pelo fato da expectativa do suprimento energético por uma substancial fração de energia solar ou outras pequenas fontes renováveis, constituir-se em uma ilusão (KORDESH \& SIMADER, 1996).

Neste sentido, alguns autores descrevem o futuro como criticamente dependente de energia. Os cenários pessimistas predizem catástrofes humanas e soluções baseadas em uma economia de energia forçada pela "volta aos estilos básicos de vida" ${ }^{1}$. No entanto, visões mais otimistas consideram que o efeito das novas tecnologias em adição ao uso da energia solar e outros recursos renováveis, conduzirão para uma melhor utilização dos combustiveis fósseis, incluindo o uso apropriado de energia atômica. 


\section{2 - Origem e História da Tecnologia}

O desejo de converter energia química de combustiveis diretamente em eletricidade existe desde 1900 e, é manifestado pela larga escala de experimentos, nos quais se tentava oxidar carvão e gás natural em pilhas eletroquímicas $^{2}$. Um resgate histórico nos leva a constatar que o princípio de funcionamento da célula a combustível $(\mathrm{CaC})$ foi verificado em 1839 pelo físico inglês Willian Robert Grove, ao combinar os gases hidrogênio e oxigênio e, gerar eletricidade e água em um processo denominado eletrólise reversa ${ }^{3}$.

Anos depois, em 1889, o termo "célula a combustivel" foi cunhado pelos cientistas Ludwig Mond e Charles Langer que tentaram, sem sucesso, produzir o primeiro dispositivo prático, usando gás natural e carvão. Outras tentativas, no inicio do $\mathrm{XX}$, para a construção de CaC que pudessem converter carvão ou carbono em energia elétrica também falharam em função da cinética dos materiais e eletrodos (ALDABÓ, 2004).

Entretanto, em 1932, ocorreram os primeiros experimentos bem sucedidos, resultantes do trabalho do engenheiro Francis Bacon, que aperfeiçoou os caríssimos catalisadores de platina ${ }^{4}$, ao utilizar um eletrólito alcalino menos corrosivo e eletrodos de níquel mais baratos. Todavia, os desafios técnicos eram muitos e somente em 1959 Bacon conseguiu demonstrar um sistema CaC de 5 $\mathrm{kW}$ capaz de alimentar uma máquina de solda .

No mesmo periodo, a National Aeronautics and Space Administration NASA começou a pesquisar um gerador de eletricidade compacto, para ser utilizado a bordo das naves de uma série de missões espaciais tripuladas. Após desistir das alternativas existentes na época, por apresentarem riscos à segurança e outros problemas técnicos relacionados ao peso e durabilidade da fonte, a NASA se voltou para o desenvolvimento da tecnologia $\mathrm{CaC}$.

\footnotetext{
Ibidem, 1996. p. 1

NETO, E. H. G. (2005).

${ }^{4}$ Utilizados por Mond e Langer em uma célula hidrogênio-oxigênio
} 
Desta forma, o sistema construido por Bacon serviu como protótipo para as CaC utilizadas no programa espacial Apollo e Gemini, responsáveis por conduzirem o vôo do Homem à lua em 1968. Não obstante, as pesquisas em CaC ressurgiram mais fortemente no mundo, quando substratos de carbono poroso com baixas cargas de catalisador providenciaram uma solução de baixo custo para os sistemas $\mathrm{CaC}$ hidrogênio-ar e, o interesse por automóveis elétricos movidos a CaC foi difundido, conduzindo assim a vários protótipos (KORDESH \& SIMADER, 1996).

Em meados de 1970, houve uma mudança na direção do interesse pela tecnologia de CaC. O sistema alcalino (Alcaline Fuel Cell - AFC) que tinha alcançado o nivel máximo de aperfeiçoamento nos programas espaciais foi substituído, nos programas mundiais de $P \& D$, pelo sistema de acido fosfórico (Phosphoric Acid Fuel Cell - PAFC), no qual constituía-se mais apropriado para aplicação estacionária de geração de energia. A tendência na ampliação de plantas de geração para larga escala foi especialmente notável no Japão, principalmente após a perda de interesse dos Estados Unidos.

Contudo, nos anos 80 e 90 destacou-se o acelerado desenvolvimento de sistemas $\mathrm{CaC}$ de carbonato fundido (Molten Carbonate Fuel Cell - MCFC) e de óxido sólido (Solid Oxide Fuel Cell - SOFC), claramente devido ao fato das plantas de $\mathrm{CaC}$ de alta temperatura apresentarem uma melhor eficiência global quando associadas ao calor. Infortunamente, aspectos relacionados à expectativa de vida dos materiais resultaram em problemas ainda em pauta.

Também em 1990, ocorre outra reviravolta no cenário tecnológico das $\mathrm{CaC}$, quando a célula a combustível de membrana trocadora de prótons (Proton Membrane Exchange - PEMFC) surge como o mais atrativo objeto de desenvolvimento. Embora esse sistema exista desde 1960, seu desempenho não foi seguro nos projetos espaciais, de forma que a atenção na época se voltou para os sistemas AFC. No entanto, as altas densidades de corrente do sistema PEMFC, obtidas a partir de pesquisas de novos tipos de membrana e catalisadores, associadas a um aperfeiçoamento na expectativa de vida operacional realimentaram o interesse por esta tecnologia (ibidem, 1996. p. 2). 
Atualmente, o cenário das $\mathrm{CaC}$ é bastante discutido e difundido internacionalmente, devido a características inerentes da tecnologia, por exemplo, à geração de energia distribuída e utilização de fontes renováveis para obtenção de hidrogênio. No caso do Brasil, os reflexos das ações conduzidas no exterior para o desenvolvimento da tecnologia CaC resultaram no Programa Brasileiro de Sistemas de Células a Combustível - ProCaC, como iniciativa do Ministério da Ciência e Tecnologia e do Centro de Gestão e Estudos Estratégicos- CGEE (MCT/CGEE, 2002).

No âmbito acadêmico, verifica-se que desde o final da década de 70 algumas atividades na área de células a combustivel no nivel nacional têm sido realizadas. Direta ou indiretamente várias instituições, tais como a Universidade Federal do Ceará, Universidade Federal do Rio de Janeiro, o Instituto de Pesquisas Tecnológicas - IPT de São Paulo e o grupo de eletroquímica de São Carlos, já se dedicaram ao estudo deste tipo de tecnologia. Recentemente, em meados de 1998, iniciou no Instituto de Pesquisas Energéticas e Nucleares IPEN/CNEN de São Paulo o estudo e desenvolvimento de sistemas, eficientes e de baixo impacto ambiental, associados a CaC (WENDT et al, 2000).

\section{3 - Sistema Conversor de Energia}

As $\mathrm{CaC}$ são células eletroquímicas que podem converter continuamente a energia quimica de um combustivel e um oxidante em energia elétrica pelo processo envolvendo essencialmente e invariavelmente um sistema eletrodoeletrólito ${ }^{5}$. Caracterizam-se por operar com alta eficiência e niveis de emissões bem abaixo dos mais rigidos padrões.

Conforme NETO (2005), a fórmula termodinâmica do ciclo de Carnot $^{6}$ mostra que uma máquina térmica não pode converter toda a energia do calor em energia mecânica, mesmo sob condições ideais, pois uma parte do calor é

\footnotetext{
Ibidem, 1996. p.9

${ }^{6}$ Máxima eficiência $=\left(\mathrm{T}_{1}-\mathrm{T}_{2}\right) / \mathrm{T} 1$
} 
perdida. Por exemplo, o motor a combustão utiliza o calor de uma fonte de energia em alta temperatura $\left(T_{1}\right)$, converte parte desse calor em energia mecânica, e perde a outra parte para um ambiente de menor temperatura $\left(T_{2}\right)$, como o ar ambiente.

No caso das células a combustivel, o processo não envolve a conversão de calor em energia mecânica, pois estas transformam a energia quimica diretamente em energia elétrica (FIG 2.1). Desta forma, a eficiência das CaC pode superar o limite de Carnot, até mesmo em baixa temperatura, como em $80^{\circ} \mathrm{C}$ (ibidem, 2005. p. 94).

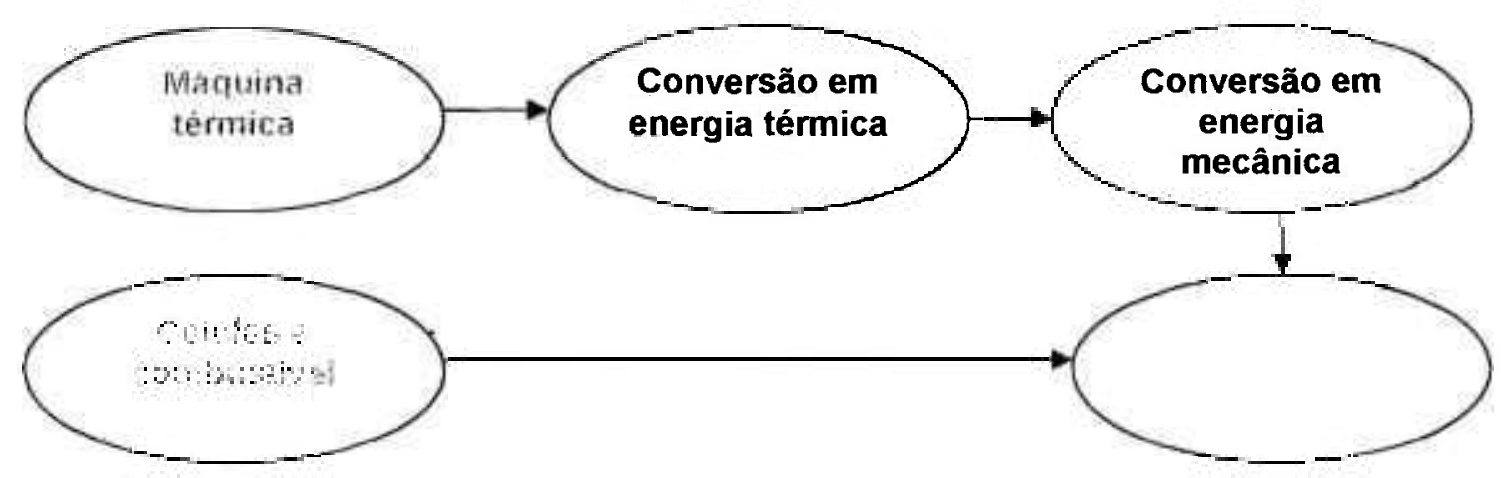

FIGURA 2.1 - Conversão direta de energia das $\mathrm{CaC}$ em comparação as tecnologias de conversão indireta.

Ademais, o sistema de $\mathrm{CaC}$ apresenta vantagens por ser modular, podendo ser construída para uma larga escala de requerimentos de potência, desde a centena de watts até a múltiplos kilowatts e megawatts, permitindo desta maneira, a construção de plantas energéticas altamente eficientes até em locais remotos. Devido às baixas emissões, as plantas de $\mathrm{CaC}$ podem ser instaladas na localidade onde a energia será consumida e, principalmente, em áreas densamente povoadas. Como resultado, as linhas de transmissão são mais econômicas e as perdas no sistema são reduzidas.

De acordo com KORDESH \& SIMADER (1996), os principios básicos da célula a combustível são similares às conhecidas baterias eletroquimicas, envolvidas em muitas atividades do nosso dia a dia. A grande diferença, no caso das baterias, é que esses dispositivos possuem estocados no seu interior a 
energia química contida nas substâncias. Quando essa energia é transformada em eletricidade, as baterias são descartadas (baterias primárias) ou recarregadas apropriadamente (baterias secundárias). No caso da $\mathrm{CaC}$, a energia química é providenciada por combustível e um oxidante armazenado fora da célula na qual as reações ocorrem, assim, a energia elétrica pode ser obtida continuamente, contanto que as células sejam supridas por esses reagentes.

\subsection{1 - Classificação das Tecnologias}

Há diferentes tipos de $\mathrm{CaC}$ e muitas formas de classificação são encontradas na literatura (WENDT et. al, 2000; 2002;. ALDABÓ, 2004). A FIG. 2.2 apresenta um exemplo razoável de uma classificação geral de tipos da tecnologia com descrições abrangendo também os quesitos: $\mathrm{CaC}$ diretas, indiretas $\mathrm{e}$ regenerativas. Nas $\mathrm{CaC}$ diretas, os produtos das reações das células são descartados, enquanto que nas células regenerativas, os reagentes ${ }^{7}$ consumidos são regenerados por um ou mais métodos, como indicado na FIG. 2.2 abaixo.

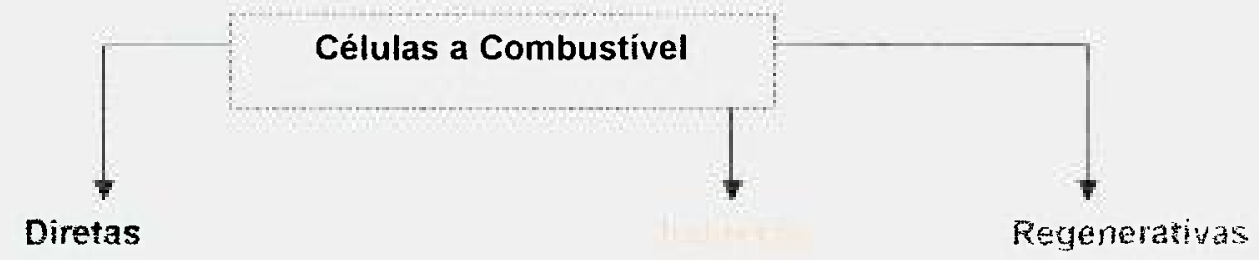

$\begin{array}{ccr}\begin{array}{c}\text { Baixa } \\ \text { temperatura }\end{array} & \begin{array}{c}\text { Temperatura } \\ \text { Intermediária }\end{array} & \begin{array}{c}\text { Alta } \\ \text { temperatura }\end{array} \\ \mathrm{H}_{2}-\mathrm{O}_{2} & \mathrm{H}_{2}-\mathrm{O}_{2} & \mathrm{H}_{2}-\mathrm{O}_{2} \\ \begin{array}{c}\text { Compostos } \\ \text { oraânicos- } \mathrm{O}_{2}\end{array} & \begin{array}{c}\text { Compostos } \\ \text { orqânicos- }\end{array} & \mathrm{CO}-\mathrm{O}_{2} \\ \begin{array}{c}\text { Compostos } \\ \text { de } \mathrm{N}_{2}-\mathrm{O}_{2}\end{array} & \text { Amônia }-\mathrm{O}_{2} & \\ \mathrm{H}_{2}- & & \\ \text { Haloaênios } & & \\ \text { Metal- }-\mathrm{O}_{2} & & \end{array}$

CaC de reforma

$\mathrm{CaC}$ bioquímicas

Combustivel e Oxidante Fonte: KORDESH \&SIMADER (1996), modificado por FUKUROZAKI (2006) 
Os dois tipos descritos anteriormente são similares a baterias primárias e secundárias $^{8}$. O terceiro, são as $\mathrm{CaC}$ indiretas, como exemplo desta categoria está a célula com reforma que usa combustiveis orgânicos passiveis de serem convertidos em hidrogênio e, a célula bioquímica, na qual uma substância bioquimica é decomposta por meio de enzimas em solução (algumas vezes providas por adição de bactérias) para produzir hidrogênio.

Uma outra subdivisão dos modelos de sistemas de células está de acordo com a temperatura de operação, considerada por muitos pesquisadores a mais apropriada. Neste propósito, a classificação adotada consiste em células de baixa, intermediária e alta temperatura de operação; respectivamente, 25 a $100^{\circ} \mathrm{C}$, de 100 a $500^{\circ} \mathrm{C}$ e, de 500 a $1000^{\circ} \mathrm{C}$ (ibidem, 1996. p. 10). Em cada uma dessas escalas de temperaturas, há diferentes padrões de $\mathrm{CaC}$ que podem ser subdivididas de acordo com o tipo de combustível (veja FIG. 2.2).

Alguns desses combustiveis podem ser disponibilizados imediatamente, como gás natural, ou facilmente produzidos, no caso do hidrogênio. Entre os compostos orgânicos, a variedade de potenciais combustiveis é concebivel, por exemplo, por hidrocarbonetos, álcoois $e$, inclusive o carbono ou grafite. Os combustiveis contendo nitrogênio utilizam a amônia, a hidrazina, entre outras, e o oxigênio, na sua forma pura ou ar, é usado praticamente em todas as $\mathrm{CaC}$ como oxidante. Também é possivel a subdivisão do ponto de vista da natureza eletroquímica do eletrólito utilizado. Esta classificação não está presente na FIG. 2.2, mas um exemplo desta pode ser observado na TAB. 2.1.

TABELA 2.1 - Classificação das CaC conforme o eletrólito utilizado

\begin{tabular}{c|c|c|c}
\hline Célula a Combustivel & Sigla & Eletrólito & Temperatura de Operação \\
\hline Alcalina & AFC & Alcalino & 50 a $200^{\circ} \mathrm{C}$ \\
\hline Membrana Trocadora de Prótons & PEMFC & Polímero & 50 a $130^{\circ} \mathrm{C}$ \\
\hline Metanol Direto & DMFC & Polimero & 60 a $130^{\circ} \mathrm{C}$ \\
\hline Acido Fosfórico & PAFC & Ácido fosfórico & 190 a $210^{\circ} \mathrm{C}$ \\
\hline Carbonato fundido & MCFC & Carbonato fundido & 630 a $650^{\circ} \mathrm{C}$ \\
\hline Óxido Sólido & SOFC & Óxido sólido & 700 a $1000^{\circ} \mathrm{C}$ \\
\hline 1 - Também conhecida com Célula a Combustivel de Polímero Eletrolítico - PEFC e como Célula a \\
Combustivel de Polímero Sólido - SPFC
\end{tabular}

Fonte: PROCaC/ CCGE/MCT (2002

${ }^{8}$ Uma quantidade de pesquisas em CaC concentra-se no desenvolvimento de células primárias e de reforma. 
Em relação à natureza de operação, os eletrólitos poliméricos são comumente utilizados em temperaturas baixas e intermediárias (pressurizados). Enquanto que os eletrólitos fundidos são ocasionalmente utilizados em temperaturas intermediárias, mas usualmente em altas (ibidem, 1996. p.11). Já os eletrólitos sólidos (por exemplo mistura de óxidos, quando o íon oxigênio é a espécie transportada) são usados em altas temperaturas. Em termos de praticidade, os sistemas $\mathrm{CaC}$ são distinguidos pelos tipos de eletrólitos utilizados seguidos dos nomes e abreviações, mais freqüentemente usados nas publicações (veja TAB 2.1).

\section{4 - Principais Vantagens}

As $\mathrm{CaC}$ oferecem inúmeras vantagens como eficiência, segurança, economia, baixas emissões, características únicas de operação ${ }^{9}$, flexibilidade de planejamento e futuro potencial de desenvolvimento. Dentre estes aspectos, destacam-se, em particular: a alta eficiência e segurança, a flexibilidade de planejamento e o desempenho ambiental.

\subsection{1 - Alta Eficiência e Sequranca}

Conforme NETO (2005), a eficiência é um valor utilizado como parâmetro para verificar a eficácia ${ }^{10}$ dos componentes, sistemas e processos. No que tange a conversões de energia, a eficiência comumente reflete a relação entre a energia realmente aproveitada e a que foi inicialmente utilizada, normalmente expressa em porcentagem.

De acordo com a termodinâmica, a conversão de energia é sempre menor que $100 \%$ e, cada conversão de energia resulta em algumas perdas. No caso das CaC é possível transformar até $90 \%$ da energia presente em um combustível em eletricidade e calor (ibidem, 1996. p. 11). A atual célula PAFC foi projetada para

\footnotetext{
${ }^{9}$ Como por exemplo, a confiabilidade no que tange ao controle de voltagem da linha de distribuição e controle de qualidade (ibidem. 1996. p 13)

${ }^{10}$ Entende-se por eficácia como a qualidade de produzir o resultado esperado e eficiência como a qualidade de produzir o resultado esperado fazendo um melhor uso dos recursos.
} 
oferecer $42 \%$ de eficiência na conversão elétrica com base em altas temperaturas. Em curto prazo será possivel que a PAFC atinja até $46 \%$ de eficiência, pelo avanço do conhecimento em ciências e engenharia (FIG. 2.3).

O Instituto de Pesquisa de Energia Elétrica - Electric Power Research Institute estima que o progresso nas células de carbonato fundido (MCFC) resultará em eficiências elétricas acima de $60 \%$, excluindo o topo do ciclo, no qual estas podem ser ainda maiores. Além disto, este parâmetro é independente do tamanho, visto que a $\mathrm{CaC}$ pode operar com a metade da taxa de capacidade, enquanto mantém uma elevada eficiência no uso do combustível (ibidem,1966, p.12).

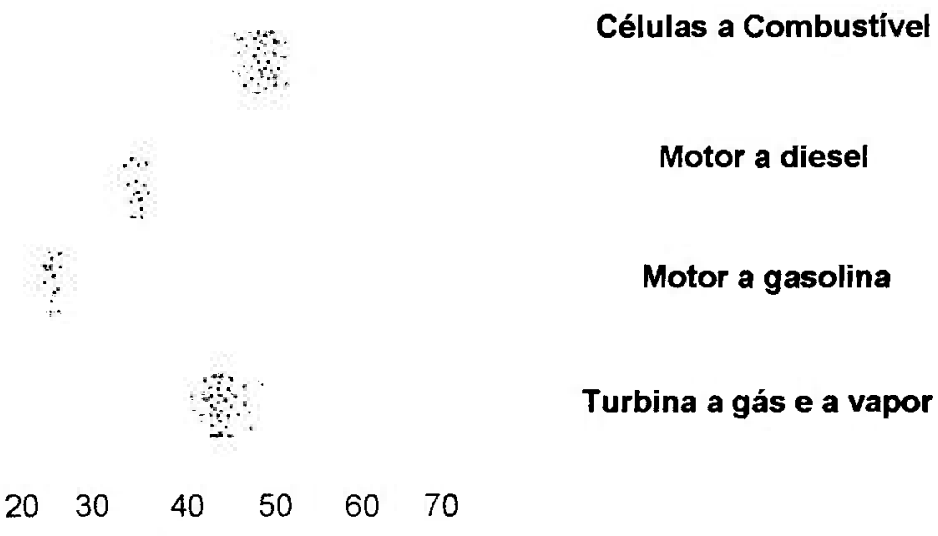

FIGURA 2.3 - Comparação das eficiências em porcentagem (\%)

Fonte: NETO, 2005

Outro atributo importante da CaC é a aptidão para cogeração, por exemplo, a produção de água quente e vapor de baixa temperatura concomitante a geração de eletricidade ${ }^{11}$. Esta taxa de eletricidade e saída térmica é de aproximadamente 1.0, enquanto na turbina a gás é em torno de 0.5 , comparativamente isto representa o dobro de saída elétrica para a mesma carga de energia. Em tamanhos pequenos até sistemas de utilidade pública, as $\mathrm{CaC}$ também são mais eficientes (por um fator 2) quando comparadas, por exemplo, com um ciclo combinado de $2 \mathrm{MW}$ e taxa de produção de calor de $15000 \mathrm{Btu} / \mathrm{kWh}$.

11 A capacidade de cogeração da $\mathrm{CaC}$ também contempla diferentes mercados de demanda de geração térmica. 
Não obstante, os sistemas $\mathrm{CaC}$ constituem-se de partes modulares e não girantes, apresentando elevada segurança em relação a turbinas de combustão de sistemas de ciclos combinados ou engenharia de combustão interna, uma vez que não há experiência ${ }^{12}$ relatada de desarranjos catastróficos, como os que ocorrem quando as partes mecânicas dos sistemas convencionais mencionados, falham. Espera-se que sistemas de $\mathrm{CaC}$ "avançados" apresentem mais vantagens em relação às tecnologias competitivas atuais.

\subsection{2 - Flexibilidade de Planejamento}

A flexibilidade de planejamento dos sistemas de $\mathrm{CaC}$, incluindo o aspecto de modularidade, resulta em benefícios estratégicos e financeiros para diversos propósitos e clientes. Segundo KORDESH \& SIMADER (1996), as plantas de geração de energia de $\mathrm{CaC}$ podem ser construidas em torno de dois anos, sendo o desempenho independente do seu tamanho; possibilitando o uso progressivo da capacidade do sistema por pequenos incrementos e, segundo as necessidades dos clientes.

Desta forma, ao igualar melhor o aumento das exigências de energia, os longos periodos de sobrecarga podem ser evitados e os custos médios fixos podem ser diminuidos. Portanto, mesmo se o crescimento do consumo é incerto, a $\mathrm{CaC}$ torna-se mais adequada à medida que sua capacidade operacional pode diminuir ou ser acelerada rapidamente em resposta a demanda.

Em adição, os benefícios obtidos com o uso da tecnologia $\mathrm{CaC}$ encontramse, além do arrefecimento de reservas marginais, a confiabilidade das pequenas unidades de geração de energia distribuída. Ou seja, a produção de eletricidade no local onde essa será consumida, possibilita, entre outros aspectos, na redução das probabilidades de falhas devido a interrupções externas de transmissão e, conseqüentemente, na mitigação de despesas de manutenção.

12 A experiència relata somente a perda de eficiência (ibidem, 1996. p.12). 
Inicialmente, as $\mathrm{CaC}$ podem ser projetadas para o abastecimento com gás natural ou nafta (amplamente disponivel como produto de baixo custo nas refinarias) nas células que requerem hidrogênio. A reforma química dos produtos ricos em hidrogênio permite o uso variado de gases de baixa quantidade de enxofre e combustiveis líquidos. O avanço do desenvolvimento das $\mathrm{CaC}$ também poderá habilitá-las a operar com carvão gaseificado.

Embora, a flexibilidade de planejamento não seja uma característica restrita a tecnologia $\mathrm{CaC}$, já que as unidades de ciclo combinado e engenharia de combustão interna apresentam, cada uma delas, algumas das caracteristicas aqui apontadas, as $\mathrm{CaC}$, combinadas com suas outras vantagens, são notadamente um recurso energético único (ibidem, 1996. p.15).

\subsection{3 - Desempenho Ambiental}

A substituição dos atuais sistemas de geração de eletricidade pela tecnologia $\mathrm{CaC}$ pode melhorar a qualidade do ar e diminuir o consumo de energia e efluentes, considerando o fato das plantas tradicionais produzirem mais particulados, óxidos de enxofre e nitrogênio do que outras fontes estacionárias industriais combinadas. As emissões da planta de $\mathrm{CaC}$ são menores daquelas especificadas pelas restritivas regulamentações ambientais (internacionais), incluindo o dióxido de carbono $\left(\mathrm{CO}_{2}\right)$, um dos principais gases responsáveis pelo efeito estufa (ibidem, 1996. p.12).

Diferentemente do que ocorre com as plantas de turbina a gás e a vapor, que requerem um uso massivo de água para o sistema de resfriamento, a reação eletroquímica da $\mathrm{CaC}$ produz como sub-produto a água, de maneira que uma pequena quantidade externa deste recurso é necessária para a operação da planta energética. Não obstante, a quantidade de efluente descartada pela $\mathrm{CaC}$ também é pequena e, sua qualidade é superior, quando comparada às plantas baseadas em combustiveis fósseis, pois não requerem um pré-tratamento para a sua disposição no meio ambiente. Além disto, não há um grande volume de residuos produzidos na operação da CaC (ibidem, 1996, p 12). 
Ainda, a natureza silenciosa da produção de energia eletroquímica, elimina uma fração substancial das fontes de ruidos associadas aos sistemas convencionais de vapor $e$, podem facilmente entrar em conformidade com os padrões da Ocupacional Health and Safety Administration - OSHA. Ademais, as exigências para uso e ocupação do solo são aceitáveis e, no caso de fontes externas de energia, os corredores de transmissão não são necessários. Por conseguinte, a $\mathrm{CaC}$, entre as tecnologias de produção de energia, é a menos perigosa, comparativamente ao seu pequeno tamanho, devido à ausência do ciclo de combustão, o estado da arte dos sistemas de segurança e baixa emissão de poluentes.

\section{5 - Tecnologia da Célula a Combustível de Membrana Trocadora de Prótons}

Dentre os diferentes tipos de $\mathrm{CaC}$, destaca-se a Célula a Combustivel de Membrana Trocadora de Prótons - PEMFC ${ }^{13}$, cujo interesse de diversos países e instituições no mundo tem aumentado rapidamente, especialmente devido ao comprometimento das indústrias automotivas em desenvolver carros movidos com esta tecnologia (PEHNT, 2001).

Estas células de baixa temperatura de operação, que utilizam uma membrana polimérica como eletrólito são as mais promissoras como fonte estacionária e também como alternativa para motores a combustão, por serem robustas e de fácil acionamento e desligamento, além das vantagens intrínsecas, como a alta eficiência com baixa emissão de poluentes.

O principio de funcionamento da PEMFC é como todas as outras CaC. A energia quimica presente no combustivel, usualmente o hidrogênio, e o oxidante, oxigênio, são completamente e eficientemente convertidos em energia elétrica, calor e água (FIG.2.4). O hidrogênio é oxidado no ânodo e o oxigênio é reduzido no câtodo na unidade da célula (RALF, 1998).

\footnotetext{
${ }^{13}$ Também conhecida como Célula a Combustivel de Membrana Polimérica Trocadora de Prótons - PEFC e de Polímero Sólido - SPFC.
} 


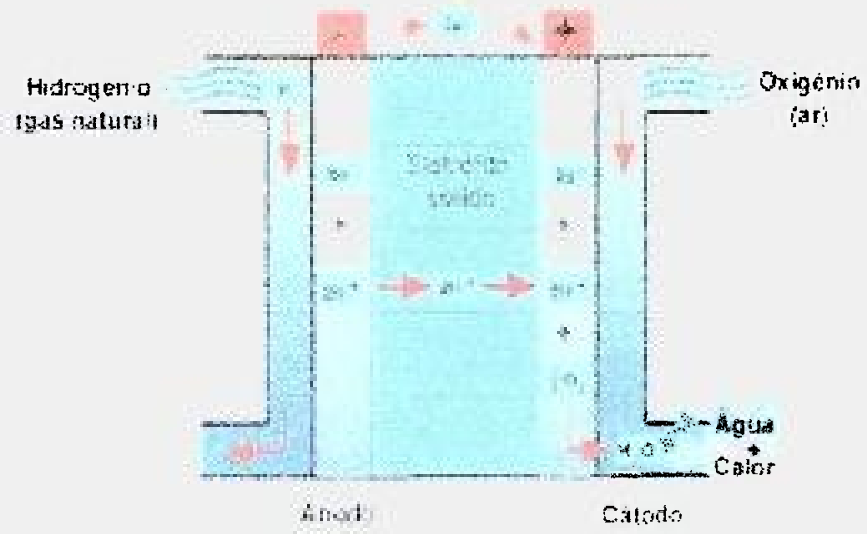

FIGURA 2.4 - Desenho esquemático da PEMFC

Fonte: ELECTROCELL, 2006

Basicamente, cada célula apresenta um conjunto eletrodo membrana planar, denominado membrane electrode assembly - MEA e, placas bipolares (FIG 2.5). O MEA é o coração da $\mathrm{CaC}$, sendo formado pela camada de eletrólito e os eletrodos de difusão gasosa - EDG, componentes extremamente importantes e delicados da célula a combustivel.

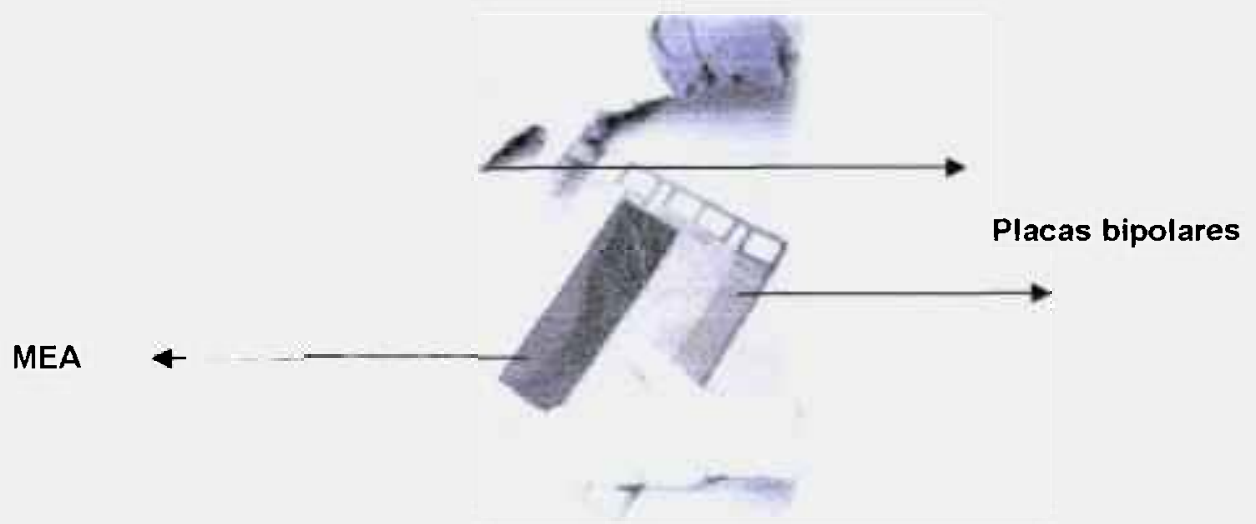

FIGURA 2.5 - MEA e célula unitária da PEMFC

Fonte: Brasil $\mathrm{H}_{2}$ Fuel Cell Energy (2005) 
O eletrólito é sólido e constitui-se de uma camada delgada de um polímero condutor protônico, já os EDG são formados por duas camadas distintas: a camada catalítica composta de nanopartículas de platina ancoradas em carvão ativado - Carbon Black e recobertos por uma dispersão do eletrólito e; a camada difusora usualmente constituida de um papel de fibra de carbono rígida - Carbon Paper ou tecido de carbono trançado - Carbon Cloth.

As placas bipolares são blocos de grafite, sulcados por canais que providenciam tanto o suprimento do combustivel e do oxidante, quanto à conexão elétrica entre as células unitárias, sendo utilizadas para separar o ânodo de uma célula do cátodo seguinte. As unidades de células são comumente dispostas eletricamente em série e sobrepostas verticalmente, formando um módulo - stack (FIG. 2.6).

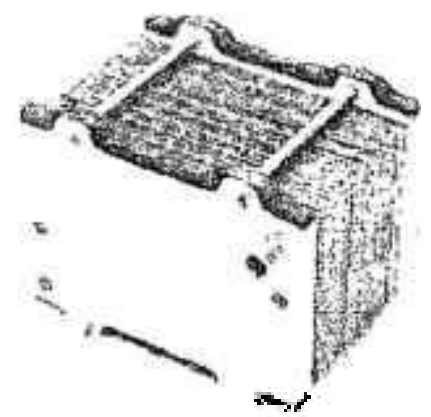

FIGURA 2.6 - Módulo da PEMFC

Fonte: Power Pulse (2006)

Em relação aos sistemas externos à célula destacam-se, dentre outros, a unidade de processamento de gás, responsável pelo fornecimento de ar e combustivel; inversor, responsável pela conversão da corrente contínua produzida no conjunto de $\mathrm{CaC}$ a corrente alternada; e trocador de calor que possibilita o gerenciamento energético entre a instalação de processamento de gás e o conjunto de $\mathrm{CaC}$.

Segundo WENDT et. al. (2000), o sistema operacional de uma CaC consiste em todos os dispositivos de acionamento e controle, bem como de segurança, que permite uma operação das células conforme as especificações de sua aplicação. Sistemas operacionais para aplicações móveis são mais 
sofisticados e precisam ser mais rápidos que os de aplicações estacionária, devido à própria dinâmica dos automóveis, por exemplo.

\subsection{1 - Evolucão Histórica do Desenvolvimento}

Esta tecnologia foi inventada pela General Electric (GE) nos anos 50 e utilizada pela NASA para fornecer energia ao projeto espacial Gemini, que tinha como principal objetivo testar equipamentos e procedimentos para o Apollo. Entretanto, a PEMFC da GE (modelo PB2) teve várias dificuldades técnicas, incluindo contaminação interna e vazamento de oxigênio pela membrana, de forma que baterias convencionais foram usadas nas Gemini 1 a 4 (NETO, 2004) ${ }^{14}$.

Desta maneira, a GE redesenhou sua PEMFC, e o novo modelo P3, apesar de alguns problemas e fraca performance na Gemini 5, serviu adequadamente para os outros vôos das Gemini. Nas missões Apollo, contudo, a tecnologia alcalina AFC foi selecionada para o comando e módulos lunares, assim como também foi escolhida para as missões do Space Shuttle uma década depois. Em 1959, Thomas Grubb e Leonard Niedrach, pesquisadores da GE, idealizaram o uso de membranas orgânicas, de troca catiônica, para utilização em células a combustível, promovendo o início das pesquisas com células a combustivel de eletrólito polimérico.

Entre 1959 e 1961, a GE desenvolveu algumas membranas fenolsulfônicas com platina depositada como catalisador. $O$ desempenho destas células a combustível era pequeno mesmo utilizando uma boa quantidade de platina no eletrodo, cerca de $5 \mathrm{mg} / \mathrm{cm}^{2}$, massa equivalente a uma atividade catalítica específica de $8 \mathrm{~mA}$ por $\mathrm{mg}$ de platina.

De acordo com WENDT et al. (2000), a carga de platina destas células era muito alta, o que tornava inviável o seu uso comercial. Ademais, devido à degradação da membrana utilizada nestas células PEMFC, o desempenho e a vida útil eram limitados. Mesmo com o alto custo e vida útil curta, os benefícios para o programa espacial foram satisfatórios, contudo a aplicação mercantil ainda estava distante.

\footnotetext{
${ }^{1.4}$ NETO.E.H.G.celulaacombustivel.com.br/cac/oconceito/cachistoria.htm. Acessado em 07/06/2004
} 
Em 1969, a segunda geração das células a combustível do tipo PEMFC da GE eram constituídas por um módulo de $350 \mathrm{~W}$, que fornecia energia para o satélite artificial Biosatellite, utilizando uma membrana melhor e fabricada pela $D u$ Pont, o Nafion $\circledast$, ainda muito utilizado atualmente (ibidem, 2004.).

Desde então, observou-se que a vida útil e o desempenho das células a combustivel de segunda geração melhoraram significativamente devido ao uso desta membrana. Não obstante, a mudança de cenário também se consolidou com a utilização de carvão ativo, ativado com platina como eletrocatalisador (ibidem, 2000. p. 542).

No final dos anos 80 , várias empresas começaram a surgir e atuar no desenvolvimento de células a combustível. Em 1988, a Ballard Technologies Corporation, hoje uma das principais fabricantes de células a combustivel para automóveis, mostrou que as células PEMFC poderiam ser aplicadas em veículos elétricos, utilizando membranas experimentais, perfluoradas, desenvolvidas pela Dow Chemical, iniciando então uma caminhada rumo ao desenvolvimento efetivo PEMFC (ibidem, 2004). Conforme ALDABÓ (2004), atualmente é o sistema mais utilizado na propulsão de veículos e nos sistemas de energia estacionária de pequena escala.

\subsection{2-Aplicacões}

As aplicações para a tecnologia de células a combustivel do tipo PEMFC são inúmeras, não apenas na área espacial e militar, como foi inicialmente, mas também em carros, ônibus, motos, caminhões, scooters, equipamentos estacionários e portáteis (FIG. 2.7) para a geração de energia em residências, comércio e indústrias (Wendt et. al, 2000; RALF, 1997), além da aplicação em equipamentos eletrônicos, como celulares e laptops. Isto se deve aos aperfeiçoamentos obtidos na fabricação e produção, assim como na densidade de potência das células PEMFC. 


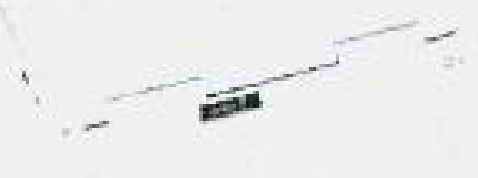

FIGURA 2.7 - Exemplo de aplicação portátil (laptop) da PEMFC Fonte: Brasil $\mathrm{H}_{2}$ Fuel Cell Energy (2005)

O processo de comercialização de automóveis de células a combustível do tipo PEMFC decorreu em função da promulgação da lei americana Clean Air Act Amendments (CAAA), em 1990, na qual a gasolina de queima mais limpa passou a ser exigida em nove cidades americanas com ar particularmente poluido.

Neste contexto, em 1994, a Daimler-Chrysler, em parceria com a empresa canadense Ballard Power Systems, apresentou o NECAR1, uma van com autonomia de $130 \mathrm{~km}$, velocidade máxima de $90 \mathrm{~km} / \mathrm{h}$ e com potência de $50 \mathrm{KW}$ utilizando a tecnologia PEMFC (ibidem, 2004). Não obstante, empresas como a Ford, Renault, Honda, Volkswagen, Toyota, Mazda, Nissan, Fiat, Susuki, Pegeout, Mitsubishi, entre outras, também investiram nesta tecnologia, participando no desenvolvimento de veículos de emissão nula ou emissão mínima de poluentes (FIG 2.8)

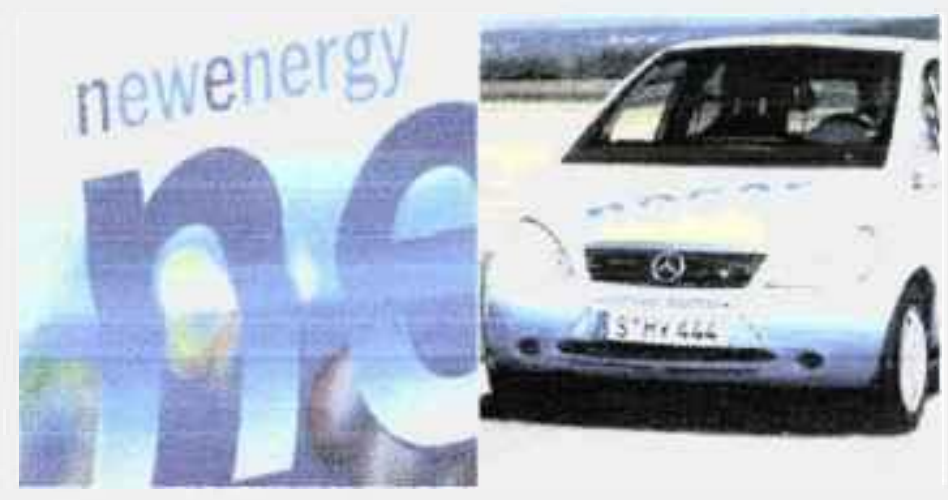

FIGURA 2.8 - Veículo de emissão nula - NECAR

Fonte: Mercedes Benz (2006) 
De acordo com PEHNT (2001), o avançado desenvolvimento das PEMFC para a indústria automotiva propiciou uma situação favorável para a aplicação destas células para geração estacionária de eletricidade. Conforme NETO (2004), a Ballard Power Systems (Canadá) têm trabalhando em pesquisas com $\mathrm{CaC}$ estacionárias tipo PEMFC de $250 \mathrm{KW}$, principalmente na Europa e Japão.

Desde 2001, cerca de 5 unidades foram instaladas na Europa, sendo a mais recente no ano 2002 em Oberhausen, Alemanha. Estes sistemas foram projetados para funcionar com gás natural, embora uma unidade instalada pela Ebara Ballard, em uma estação de tratamento de água no Japão seja alimentada por gás metano, obtido através de um digestor anaeróbico, a primeira PEMFC deste tipo.

Também a General Motor (GM) vem desenvolvendo células a combustivel do tipo PEMFC para aplicação em sistemas estacionários, assim como para o seu tradicional mercado automotivo, e planeja vender, a partir de 2005 , unidades de $75 \mathrm{~kW}$ para indústrias que necessitam principalmente de energia ininterrupta e de excelente qualidade.

Outras empresas, como Hydrogenics (Canadá), Nuvera Fue/Cells (Itália, USA) e Plug Power (USA), estão atuando no desenvolvimento desta tecnologia para a geração de eletricidade em unidades estacionárias e sua inserção no mercado. Além das aplicações automotiva e estacionária, um mercado potencial é o de geração de energia portátil, desde PEMFC para laptops e celulares, por exemplo, até energia para equipamentos maiores, mas que possam ser transportados e precisam de energia por longo período.

Atualmente, há no mundo unidades de demonstração em operação gerando uma potência de $50 \mathrm{~kW}$ e outras em desenvolvimento produzindo cerca de $250 \mathrm{~kW}$ (NETO, 2005). Embora esta tecnologia se encontre em acelerado desenvolvimento e apresente um grande número de vantagens durante a fase em uso e diversas aplicações, os obstáculos para a sua ampla inserção no mercado envolvem, além de custos relacionados ao MEA, impactos ambientais relacionados a outras etapas do ciclo de vida desta tecnologia, especificamente na manufatura e destino final da $\mathrm{CaC}$. 
Neste sentido, uma das técnicas que estão sendo desenvolvidas e utilizadas para avaliar os efeitos ambientais oriundos de toda a cadeia produtiva de um bem ou serviço é a Avaliação do Ciclo de Vida - ACV, pois as informações reunidas, no âmbito conceitual desta ferramenta, permitem quantificar tanto as suas repercussões anteriores, quanto as posteriores. Hoje em dia, a ACV se apresenta como um dos mais importantes procedimentos de gestão ambiental e prevenção à poluição, integrando a série ISO 14000. 


\section{3 - AVALIAÇÃO DO CICLO DE VIDA}

Assim como os organismos vivos, todo o produto tem uma "vida" que se inicia com o projeto, seguido pela extração de recursos, produção de materiais, a manufatura, o uso e por fim as ações envolvidas no fim da vida útil, tais como: coleta, reuso, reciclagem e disposição de resíduos (UNEP/SETAC, 2005). Estas atividades ou processos resultam em impactos ambientais devido ao consumo de recursos, emissões de substâncias no ambiente natural e trocas ambientais, como por exemplo à radiação (REBITZER e colaboradores , 2004).

Neste sentido, a Avaliação do Ciclo de Vida - ACV é uma abordagem metodológica para estimar e avaliar os impactos atribuídos à cadeia do produto, tais como: as mudanças climáticas, depleção do ozônio estratosférico, a criação do ozônio tropoesférico (smog), eutrofização, acidificação, efeitos toxicológicos na saúde humana e ecossistemas, depleção dos recursos, entre outros.

Quando conduzimos a ACV, a fase do projeto do produto é usualmente excluída pois, freqüentemente, admite-se que esta etapa não contribui significativamente para análise. Contudo, é importante notar que as decisões tomadas durante o projeto influenciam significativamente os aspectos ambientais de outros estágios do ciclo de vida. Por exemplo, o projeto de um automóvel pode determinar o consumo do combustivel e as emissões por quilômetro rodado na fase em uso, bem como possibilitar opções de reciclagem na etapa de fim de vida (ibidem, 2004. p. 702).

Desta forma, se o objetivo da ACV é aperfeiçoar os bens e serviços (uma das mais importantes aplicações da ACV), o estudo pode ser conduzido, quando possivel, no projeto e, concomitantemente, a outros procedimentos desta etapa. Isto se aplica analogamente à melhoria do processo do ciclo de vida do produto, principalmente se existir probabilidade de ocorrer interações com outros estágios do seu ciclo de vida. 
Segundo o UNEPISETAC (2005), em todos os estágios do ciclo de vida do produto ocorre intercâmbio com outros sistemas, desta forma o ciclo é denominado aberto, enquanto os materiais, energia, trabalho, tecnologia e dinheiro são exigidos e as substâncias são emitidas para o meio ambiente. Assim sendo, as relações entre o domínio ambiental, econômico e social são totalmente dinâmicas.

Embora, a implementação de tecnologias limpas possa mitigar a poluição no meio ambiente, em contrapartida propicia um aumento no custo de produção, pelo menos em um curto tempo. Neste caso, na ACV, todas as decisões relacionadas às conseqüências do ciclo de vida total (do berço ao túmulo) podem ser baseadas na análise, incluindo também as questões do âmbito social e econômico. Esta prática tem resultado em um balanço razoável entre os efeitos positivos e negativos, no seu sentido mais amplo, de um determinado produto.

Neste panorama, a atenção dada a ACV tem sido crescente nestes últimos dez anos e ainda que este aumento no interesse não seja surpreendente, a vantagem desta abordagem metodológica em fornecer uma visão como um todo de um único processo (como a produção ou consumo de um produto) tem induzido governos e organizações privadas a adotá-la (REBITZER et. al, 2004).

\section{1 - Breve Histórico e Definições}

De acordo VIGON et al (1993), os primeiros estudos de avaliação ambiental de produtos situam-se no início da década de 60 e começo de 70 , sendo inicialmente inventários de consumo energético. No final da década, no entanto, e mais ainda após a divulgação do relatório do Clube de Roma, houve um aumento da preocupação com o esgotamento de recursos naturais, fazendo com que seu consumo fosse igualmente incluido nas análises.

O estudo mais conhecido desta fase inicial da ACV foi à análise que a Coca-Cola encomendou para o Midwest Research Institute, cujo relatório publicado em 1969 comparava diversas embalagens de bebida, no que diz respeito a emissões ao ambiente e consumo de recursos naturais. Este tipo de estudo passou a receber o nome de Resource Environmental Profile Analysis - 
REPA, juntamente com o qual desenvolveu-se na Europa o método Ecobalance, bastante semelhante.

Estes trabalhos tiveram posteriormente grande repercussão, principalmente entre 1973 e 1975, quando devido à crise do petróleo, governos começaram a demandar uma grande quantidade de estudos detalhados de alternativas energéticas aos combustiveis fósseis. No entanto, passado o periodo crítico da crise o interesse pela ACV decresceu, e na segunda metade da década de 70 foram realizados poucos estudos (CURRAN, 1996).

Porém, na década de 80 , face à preocupação com o destino de resíduos, principaimente de embalagens, ressurge 0 interesse por ferramentas de comparação e avaliação de desempenho ambiental. Em 1985, a ACV é escolhida pelos países da Comunidade Européia para o auto-monitoramento de empresas e seus consumos de matéria e energia.

Desde então o interesse pela ACV vem aumentando, com uma diversificação cada vez maior de usos e usuários. Diversas instituições têm buscado uma base conceitual sólida e uniforme, entre as quais destaca-se 0 papel desempenhado pela Society of Environmental Toxicology and Chemistry SETAC, que vem trabalhando com a ACV desde 1990 e, a definiu como um processo para:

* Avaliar as cargas ambientais associadas a um produto, processo ou atividade, através da identificação e quantificação de energia e materiais usados e resíduos liberados;

- Avaliar o impacto da energia e materiais lançados no meio ambiente;

Identificar e avaliar as oportunidades que afetam o melhoramento ambiental durante todo o ciclo de vida do processo, produto ou atividade, envolvendo a extração e o processamento de matérias primas brutas, manufatura, transporte, distribuição, uso, reuso, manutenção, reciclagem e destinação final.

Entretanto, em virtude da crescente utilização da ACV e das discussões a este respeito, a acepção proposta pela International Organization for Standardization - ISO, tem recebido maior destaque. A ISO conceitua a ACV 
como uma técnica para avaliar os aspectos e os potenciais impactos ambientais associados a um produto (ou serviço) pela:

* Compilação de um inventário de entradas e saídas relevantes do sistema de um produto;

* A avaliação dos impactos ambientais potenciais associados a estas entradas e saída;

* A interpretação dos resultados da análise do inventário e das etapas de avaliação do impacto em relação aos objetivos do estudo.

Segundo TOSTA \& KIPERSTOCK (2005), a definição proposta pela SETAC foi feita no início da década de 90 , enquanto que a ISO a definiu em 1997, já incorporando, desta forma, as conclusões provenientes de discussões posteriores. Neste sentido, quanto à padronização propriamente dita, a ISO, baseada inicialmente em seminários e publicações da SETAC e de algumas outras instituições, elaborou e publicou as seguintes normas: ISO 14.040 (1997), ISO 14.041 (1998), ISO 14.042 (2000a) e ISO 14.043 (2000b).

Essas normas definem requisitos gerais para a condução de ACV e estabelecem critérios para a divulgação dos resultados ao público. O propósito destas é fornecer para as organizações, ferramentas para a tomada de decisão, bem como a avaliação de alternativas sobre o método de manufatura.

Também podem ser usadas para dar apoio às declarações de rótulos ambientais ou para selecionar indicadores ambientais. Além dessas normas, a ISO publicou dois Relatórios Técnicos (TR) e uma Especificação técnica (TS), a saber: ISO/ TR 14.047 (2003); ISO/ TS 14.048 (2002) ISO/ TR 14.049 (2000c).

No Brasil, a Associação Brasileira de Normas Técnicas (ABNT) publicou até o presente momento apenas três versões:

- A NBR ISO 14.040 (2001) - Avaliação do Ciclo de Vida: Princípios e estrutura (2001),

* A NBR ISO 14.041 (2004) - Avaliação do Ciclo de Vida: Definição de Objetivo e Escopo e Análise de Inventário, e

* A NBR ISO 14042 (2004) - Avaliação do Ciclo de Vida : Avaliação do Impacto do Ciclo de Vida (2004). 


\section{2 - Guia e Marco Metodológico}

Tal como a NBR ISO 14040 (2001) define atualmente, a ACV consta de quatro componentes, como se observa na FIG. 3.1:

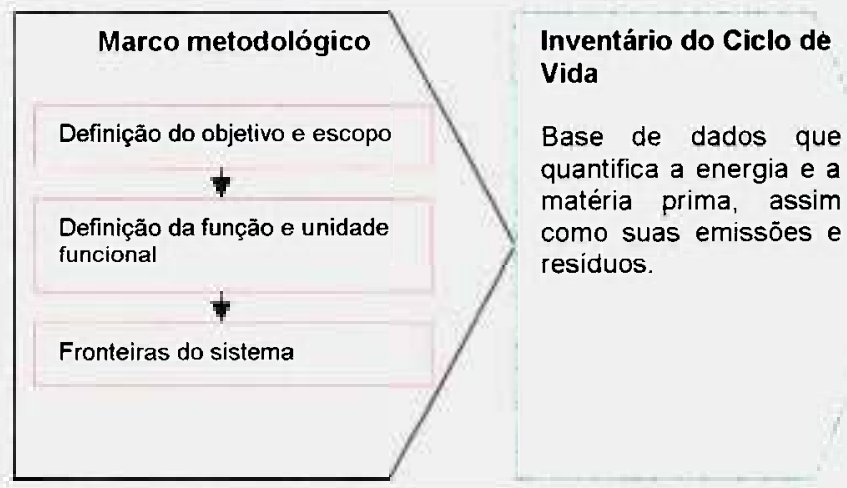

\section{Avaliação de Impacto \\ Processo para avaliar e ponderar os efeitos das cargas ambientais dos dados do inventário.}

\author{
Interpretação ou \\ melhorias \\ Avaliação sistemática \\ das necessidades e \\ oportunidades para \\ reduzir 0 impacto \\ ambiental.
}

FIGURA 3.1 - Etapas da avaliação do ciclo de vida Fonte - SUPPEN \& ABITIA, 2005

1)- Marco metodológico: inclui a definição do objetivo, escopo e alcance, função, unidade funcional e fronteiras do sistema.

2)- Inventário do Ciclo de Vida (ICV): corresponde à coleta e quantificação de todas as variáveis envolvidas: matéria-prima, energia, transporte, emissões para o ar, água e solo, durante o ciclo de vida de um sistema de produto, bem como seus processos ou atividades.

3)- Avaliação do impacto do ciclo de vida (AICV): consiste na interpretação da informação gerada na análise do ICV mediante a determinação das relações existentes entre as entradas e saídas para o meio ambiente, classificando os efeitos/cargas em diferentes categorias de impacto ambiental.

4)- Interpretação ou avaliação das melhorias: a partir das conseqüências ocasionadas pelas entradas e saidas, busca-se o estabelecimento de prioridades para as melhorias no sistema. 


\subsection{1 - Objetivo e Escopo}

Nesta fase são definidos a razão principal para a condução do estudo, sua abrangência e limites, a função, a unidade funcional ${ }^{1}$, a metodologia e os procedimentos considerados necessários para a garantia da qualidade. A norma ISO 14040 preconiza que na definição dos objetivos seja esclarecida de forma clara e inequívoca a utilização que se pretende dar aos resultados do estudo, a quem se destina e o processo de revisão crítica a ser adotado.

De uma forma simplificada CHEHEBE (1997), estabelece que o conteúdo mínimo do escopo de um estudo de ACV deve referir-se às suas três dimensões: onde iniciar e parar o estudo do ciclo de vida (a extensão da ACV), quantos e quais subsistemas incluir (a largura da ACV), e o nivel de detalhes do estudo (a profundidade da ACV) (FIG. 3.2)

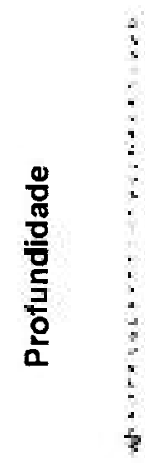

FIGURA 3.2 - Dimensões do escopo de estudo da ACV Fonte: CHEHEBE, 1996. 
Em outros termos, na definição do escopo devem ser considerados: a função e unidade funcional, as fronteiras do sistema, os requisitos da qualidade dos dados, as comparações entre sistemas e considerações sobre a análise crítica (NBR, ISO 14040). De acordo com TILLMAN \& BAUMANN (1995), as fronteiras podem ser definidas como:

* Fronteiras em relação ao sistema natural : são os limites que indicam onde seu ciclo de vida se inicia e termina, em relação ao meio natural;

* Fronteiras em relação a outros sistemas: em geral, cada sistema de produto tem associado uma rede de outros sistemas, como produção de insumos, obtenção de matérias-primas, co-produtos gerados, entre outros. Deve-se delimitar dentro desta rede quais processos serão ou não estudados, sob pena de estarmos tentando abranger um universo demasiadamente amplo;

* Fronteiras geográficas: define onde cada processo será considerado como realizado, uma vez que cada localidade possui características que podem fazer o resultado se tornar inadequado (por exemplo, cada país possui uma matriz energética, e o uso de um modelo de geração da Alemanha, por exemplo, é inadequado ao Brasil);

* Fronteira temporal: considera o momento para o qual os dados levantados terão validade, ou seja, se será estudada uma situação atual, passada ou ainda cenários de futuro, e

* Fronteiras de bens de capital: determina se serão incluídas ou não no estudo as infra-estruturas necessárias para a realização dos processos (edifícios das fábricas, estradas, entre outros).

Em relação aos requisitos da qualidade dos dados, estes especificam, em termos gerais, as caracteristicas dos dados necessários ao estudo. Quando um estudo é usado para apoiar uma afirmação comparativa que é disponibilizada ao público, estes requisitos devem ser mencionados, assim como a unidade funcional e equivalência entre os sistemas.

Na prática, o delineamento do contorno do sistema a ser estudado deve ser realizado com extremo cuidado, pois somos limitados pelos recursos financeiros e 
pelo tempo. $\mathrm{Na} A C V$, assim como em várias técnicas de modelagem, existem certas tensões entre a precisão e a praticidade.

Deve-se, portanto, percorrer caminhos que tornem o estudo gerenciável, prático, econômico, sem descuidar, no entanto, da confiabilidade do modelo. Em todos os casos, o princípio básico a ser aplicado é: menos é melhor. Em resumo, ao iniciar-se uma ACV de um produto torna-se crítico um claro estabelecimento do objetivo e do escopo do estudo (CHEHEBE, 1997).

\subsection{2 - Inventário do Ciclo de Vida - ICV}

Uma vez que o objetivo e o escopo do estudo foram estabelecidos, a próxima fase da ACV é o inventário do ciclo de Vida, na qual se desenvolve um diagrama do fluxo de energia e matéria-prima, incluindo a identificação e quantificação das entradas e saídas de cada etapa do ciclo de vida de um sistema produtivo (FIG. 3.3).

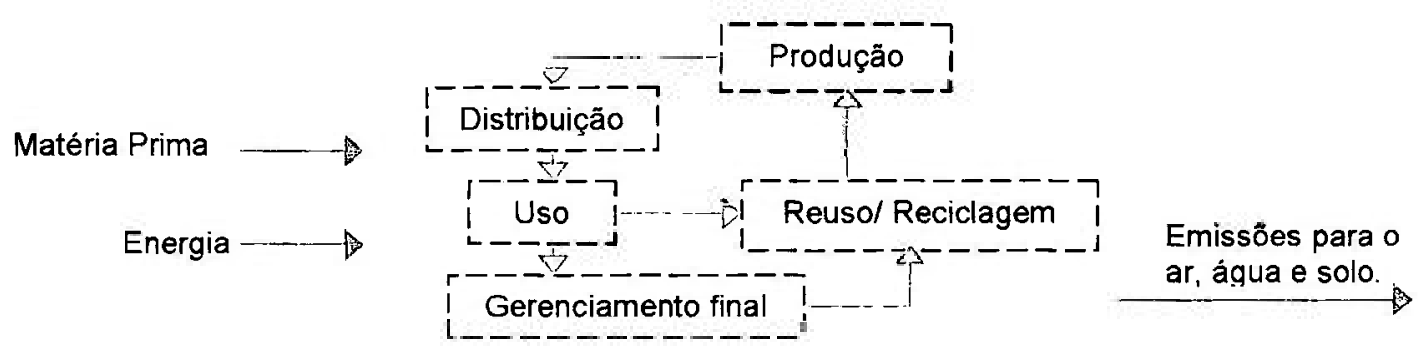

FIGURA 3.3 - Exemplo de um diagrama de fluxo de um sistema e processos de um produto.

Os dados de um ICV são informações que descrevem os fluxos de entrada e saída de um determinado modelo de sistema produtivo (técnico), ambientalmente relevantes. Como exemplos de sistemas estudados em uma ACV podemos citar: trechos de uma linha produtiva, unidades industriais inteiras, rotas de transporte, até os limite de um determinado produto desde a sua concepção até o fim da sua vida útil (CALDEIRA-PIRES et. al, 2005).

Não obstante, estes sistemas podem ser estruturas internas, descritas por sua vez por outros sub-sistemas. Desta forma, o ICV compreende na realidade 
um conjunto de ICV dos mais diversos sistemas e subsistemas que compõem um parque produtivo de uma determinada região.

Neste contexto, o inventário, na prática, é difícil e trabalhoso de ser executado por uma série de razões que vão desde a ausência de dados conhecidos até a necessidade de estimá-los à qualidade do dado disponivel. De uma forma geral , a norma ISO 14.040 (2001) estabelece que um esquema geral para o inventário deve ser constituido:

* Da apresentação do sistema de produto a ser estudado e dos limites considerados em termos dos estágios de Ciclo de Vida, unidades de processo e entradas e saídas do sistema;

* Da base para comparação entre sistemas (em estudos comparativos);

* Dos procedimentos de cálculo e da coleta de dados, incluindo-se as regras para alocação de produtos e o tratamento dispensável à energia;

* Dos elementos necessários ao uma correta interpretação por parte do leitor, dos resultados da análise do inventário.

Estes procedimentos são importantes para a análise do inventário do ciclo de vida, pois a condução do inventário é um processo iterativo. Destarte, a seqüência de eventos invariavelmente envolve a checagem de procedimentos de forma a assegurar que os requisitos de qualidade estabelecidos na primeira fase estejam sendo obedecidos (NBR ISO 14041, 2004).

\subsection{3 - Avaliacão de Impacto do Ciclo de Vida - AlCV}

A fase de AICV é dirigida à avaliação da significância de impactos potenciais, usando os resultados da análise do inventário. Em geral, este processo envolve a associação dos dados ICV com impactos ambientais específicos e a tentativa de compreensão destes.

De acordo com a NBR ISO 14042 (2004), a estrutura geral da AICV é composta por diversos elementos obrigatórios que convertem os resultados do ICV em resultados dos indicadores (FIG. 3.4). 


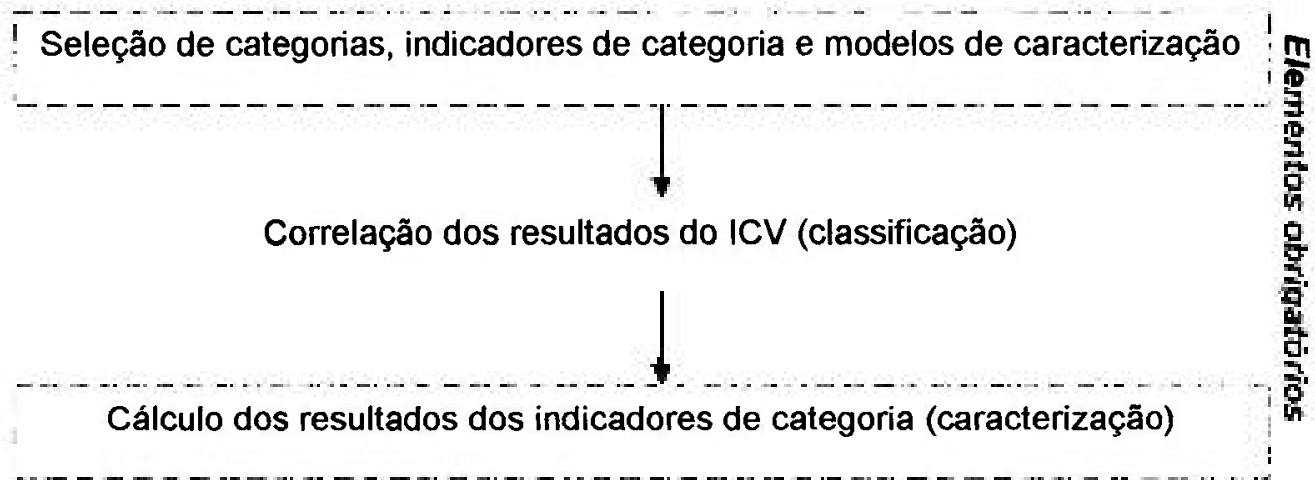

\section{Resultado dos indicadores de cateqoria (Derfil da AICV)}

FIGURA 3.4 - Estrutura conceitual da AICV

Fonte: NBR ISO 14041 (2004)

Conforme CARVALHO (2000), a classificação é um passo qualitativo baseado na análise cientifica de aspectos ambientais relevantes. Este procedimento visa relacionar os dados de entrada e saida do inventário aos potenciais impactos ambientais, isto é, categorias de impactos. Porém, não existe até hoje um consenso sobre uma lista única de categorias (TAB 3.1).

TABELA 3.1 - Exemplos de listas de seleção de categorias de impactos

\begin{tabular}{|c|c|c|}
\hline UNEP (2005) & LIME (2003) $^{1}$ & TRACI (2003) \\
\hline Depleção da camada de ozônio & Aquecimento global & Aquecimento global \\
\hline Mudanças climáticas & Depleção da camada de ozônio & Depleção da camada de ozônio \\
\hline Toxicidade humana & Acidificação & Formação de ozónio \\
\hline Acidentes & Eutrofização & Acidificação \\
\hline indicadores de smog fotoquímico & Criação de oxidantes fotoquimicos & Eutrofizaçăo \\
\hline Ruidos & Contaminação da atmosfera urbana & Saúde humana (câncer) \\
\hline Acidificação & Toxicidade humana & Saúde humana (outras doenças) \\
\hline Eutrofização & Ecotoxicidade & Saúde humana (contaminantes) \\
\hline Ecotoxicidade & Uso do solo & Ecotoxicidade \\
\hline Uso do solo/perda de habitat & Consumo de recursos & Esgotamento de combustiveis fosseis \\
\hline Dispersão de espécies/ organismos & Residuos & Uso do solo \\
\hline Uso de recursos naturais & & Uso da água \\
\hline Residuos & & \\
\hline
\end{tabular}


Já a caracterização corresponde a um procedimento quantitativo (com os mesmos princípios da avaliação qualitativa), cujo propósito constitui-se na determinação da contribuição relativa de cada entrada e saída para as categorias de impactos selecionadas, por meio de modelos de caracterização e indicadores de categorias (TAB. 3.2)

TABELA 3.2 - Exemplo de indicador e modelo de caracterização

\begin{tabular}{|c|c|}
\hline Elemento & Exemplo \\
\hline Categoria de impacto & Mudança climática \\
\hline Resultados do ICV & Gases do efeito estufa \\
\hline Modelo de caracterização & Modelo IPCC * \\
\hline Indicador de categoria & Forçamento radiativo infravermelho $\left(\mathrm{W} / \mathrm{m}^{2}\right)$ \\
\hline Fator de caracterização & Potencial de aquecimento global de cada gás do efeito estufa $\left(\mathrm{Kg} \mathrm{CO}_{2}{ }^{\text {equivalente }} / \mathrm{kg}\right.$ gás) \\
\hline Resultado do indicador & $\mathrm{Kg} \mathrm{CO}_{2}$ equivalionte \\
\hline Ponto final da categoria & Recife de corais, florestas, plantações. \\
\hline Relevância ambiental & Nivel de correlação entre o indicador de categoria e o ponto final \\
\hline
\end{tabular}

Fonte: NBR ISO 14042, 2004

Todavia, é importante ressaltar que a estrutura metodológica e científica para a avaliação ainda está sendo construida e modelos de categorias de impacto (incluindo caracterização e indicadores) estão em diferentes estágios de desenvolvimento. Assim sendo, não há nenhuma metodologia aceita de forma geral para a associação consistente e acurada de dados de inventário com impactos potenciais especificos (Cf. NBR ISO 14040, 2001). Portanto, os niveis de detalhe, escolha dos impactos a serem avaliados e a técnica utilizada dependem do objetivo e do escopo do estudo.

\subsection{4-Interpretacão}

A ISO $14043(2000 b)$ caracteriza a interpretação em linhas gerais, na identificação e análise dos resultados obtidos nas fases de inventário ou avaliação de impacto de acordo com o objetivo e o escopo previamente definidos para o estudo. Os resultados dessa fase podem tomar a forma de conclusões e recomendações aos tomadores de decisão. 
A fase de interpretação de uma ACV compreende as três etapas:

1)- Identificação das questões ambientais mais significativas baseadas nos resultados da análise do inventário ou $A C V$;

2)- avaliação que pode incluir elementos tais como a checagem da integridade e, 3)- sensibilidade e consistência; conclusões, recomendações e relatórios sobre as questões ambientais significativas.

Embora decisões e ações subseqüentes possam incorporar implicações pertinentes nas constatações da interpretação, estas se situam além do escopo de uma ACV, uma vez que outros fatores, tais como desempenho técnico, aspectos econômicos e sociais também são considerados (NBR ISO 14040, 2001).

\section{3 - Avaliação do Ciclo de Vida Simplificada}

Segundo CHRISTIANSEN (1997), a ACV Simplificada é uma aplicação da metodologia de ACV para uma avaliação abrangente, isto é, cobrindo todo o ciclo de vida, mas superficialmente, por exemplo, usando dados gerais (qualitativos e/ou quantitativos), modelo padrão para transporte ou produção de energia, seguidos por uma avaliação simplificada; focando isoladamente ou em conjunto: os aspectos ambientais; os potenciais de impactos ambientais; os estágios do ciclo de vida; bem como as fases da ACV mais importantes.

O objetivo da ACV simplificada é fornecer essencialmente os mesmos resultados de uma $A C V$ detalhada, mas com uma significativa redução em tempo e custos despendidos. No entanto, a simplificação causa um dilema já que ela pode afetar a acuracidade e confiabilidade dos resultados da ACV. Por isso, o objetivo primário é identificar as áreas dentro da ACV que podem ser omitidas ou simplificadas sem comprometer significativamente os resultados finais.

Segundo HUNT et. al (1998), a U.S Environmental Protection Agency EPA e o Research Institute Triangle - RTI cooperaram para analisar várias técnicas de simplificação da ACV, direcionando-se para os métodos que reduzem 
os esforços no inventário do ciclo de vida pela aplicação de diferentes cortes, como por exemplo, por uma eliminação deliberada de processos do inventário.

Concluiu-se, baseado no diagrama dos fluxos que se iniciam na extração do recurso e terminam na disposição final, que não poderiam ser dadas recomendações universais para cortes horizontais na análise, pois a taxa de sucesso da simplificação, por diferentes métodos, bastante arbitrários e dependendo de uma única aplicação e fluxo de referência, expressou o mesmo nivel de detalhamento do ranking das ACV pormenorizadas (Veja TAB. 3.3)

TABELA 3.3 - Análise dos métodos de simplificação da ACV

\begin{tabular}{l|l|c}
\hline \multicolumn{1}{c|}{ Método de corte } & \multicolumn{1}{|c|}{ Descrição $^{1}$} & Taxa de sucesso $^{2}$ \\
\hline $\begin{array}{l}\text { Remoção de componentes do } \\
\text { topo do ciclo }\end{array}$ & $\begin{array}{l}\text { Todos os processos prioritários para a produção da } \\
\text { matéria prima são excluidos (e.g. polimerização) }\end{array}$ & $58 \%$ \\
\hline $\begin{array}{l}\text { Rẹmoção parcial de componentes } \\
\text { do topo do ciclo }\end{array}$ & $\begin{array}{l}\text { Como acima, mas um dos passos precedentes é } \\
\text { incluído (e.g, produção de monômeros) }\end{array}$ & $70 \%$ \\
\hline $\begin{array}{l}\text { Remoção de componentes da } \\
\text { base do ciclo }\end{array}$ & $\begin{array}{l}\text { Todos os estágios depois da produção de matéria } \\
\text { prima são excluídos (e.g manufatura, uso) }\end{array}$ \\
\hline $\begin{array}{l}\text { Remoção de componentes do } \\
\text { topo e da base do ciclo }\end{array}$ & $\begin{array}{l}\text { Somente a produção de matéria prima é incluída } \\
\text { (e.g polimerização) }\end{array}$ & $67 \%$ \\
\hline $\begin{array}{l}\text { 1-Aplicável a embalagens, industrias químicas, entre outros. } \\
\text { 2- Mesmo ranking de detalhamento da ACV pormenorizada }\end{array}$ & $35 \%$ \\
\hline
\end{tabular}

Fonte: HUNT et. al , 1998

No caso dos cortes verticais, as conclusões indicaram que geralmente é preferivel a coleta de dados para todos os estágios e aspectos ambientais relevantes, porém em menor detalhe, do que a eliminação de processos de qualquer estágio do ciclo. Isto implica em uma identificação da prioridade ou préavaliação da ACV antes de simplificar o inventário. O grupo de trabalho da SETAC também enfatiza a importância deste procedimento como primeiro passo da simplificação da ACV (DEBEAUFORT-LANGEVELD et. al, 1997 apud REBITZER et. al, 2004)

O resultado do estudo (citado anteriormente em HUNT et. al, 1998) produziu como sugestão um procedimento geral para a simplificação da ACV, consistindo de três estágios que são iterativamente interligados (FIG.3.5). 


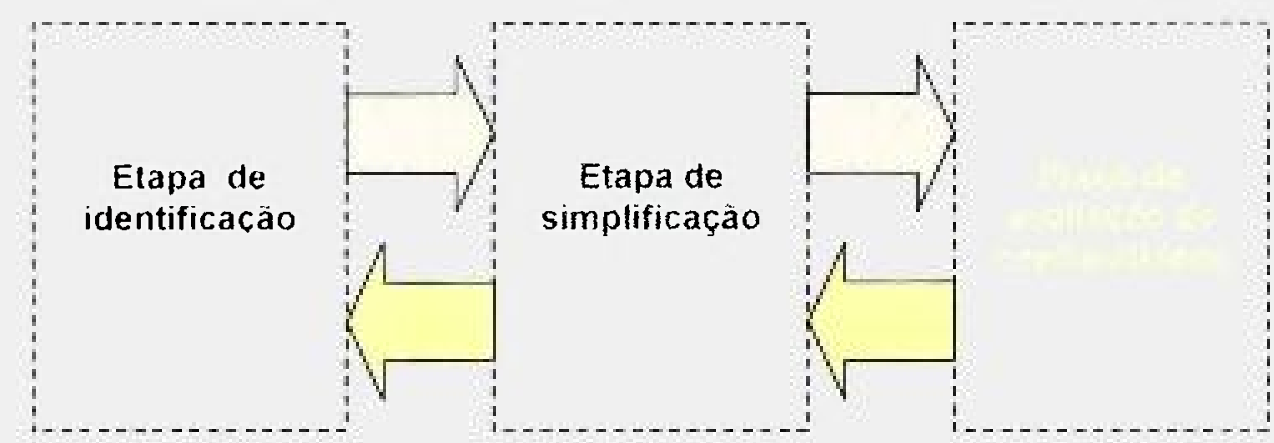

:FIGURA 3.5 - Procedimento de simplificação da ACV

Fonte: DEBEAUFORT-LANGEVELD et. al, 1997 apud REBITZER et. al, 2004)

Identificação: identificar aquelas partes do sistema (ciclo de vida) ou dos fluxos elementares que são importantes ou que tem lacunas de dados;

* Simplificação: usar os resultados da identificação de forma a focar o trabalho principalmente nas partes importantes do sistema ou fluxos elementares;

* Avaliação de Confiabilidade: checar se a simplificação não reduziu significativamente a confiabilidade dos resultados totais.

Por fim, desde que o relatório esteja de acordo com as exigências do padrão ISO, a ACV simplificada pode ser usada para estudos externos à parte interessada - stakeholders. Ė importante ainda que, para evitar interpretações indevidas dos resultados, os responsáveis pela ACV explicitem as limitações do estudo, por exemplo, declarando os métodos de simplificação utilizados.

\section{4 -Restrições a Prática da Avaliação do Ciclo de Vida}

Durante 25 anos, importantes organizações cientificas e empresariais tem trabalhado no desenvolvimento da ACV, direcionado esforços na aplicação desta metodologia em diferentes setores industrials e de serviços. Segundo CALDEIRAPIRES (2005), as pesquisas têm feito com que o método seja mais preciso, mais confiável, porém mais complexo, refletindo assim em dificuldades das pequenas e médias empresas aplicaram a ACV. 
Outro aspecto restritivo diz respeito à necessidade de uma grande quantidade de dados. Havendo ou não um banco de informações que descrevam a ICV das commodities básicas, os processos de produção são específicos casoa -caso e se assentam em parâmetros técnicos, o que por sua vez torna ainda mais difícil a coleta e o fornecimento de documentos, exigindo uma maior quantidade de pesquisas para aprofundar o conhecimento sobre o tratamento dos processos produtivos da ACV.

Ainda, o projeto ambientalmente amigável de novos produtos e processos não é dependente só de materiais. Desta forma, as organizações precisam de uma infra-estrutura e de assessoramento na etapa de coleta de dados e do seu uso em uma ACV nos seus processos de manufatura, além de modelos confiáveis de ACV (e já aceitos pela comunidade) para as etapas consideradas relevantes na cadeia produtiva.

Não obstante, embora exista uma quantidade considerável de elementos inventariados, notadamente nos paises desenvolvidos, ainda existem grandes restrições ao uso prático destas informações. Isto ocorre devido as diferentes bases de dados e as freqüentes falhas na informação existente, por exemplo, origem, limites e validação, afetando diretamente a qualidade dos resultados de uma ACV. Em geral não existem atualizações rotineiras nem um processo de harmonização para garantir a qualidade do ICV (ibidem, 2005. p.23).

\section{5 - Importância do Uso da Avaliação do Ciclo de Vida}

Diante de um mercado cada vez mais globalizado e ambientalmente regulado, a Avaliação do Ciclo de Vida vem sendo amplamente utilizada, entre os países desenvolvidos, como ferramenta para orientar politicas de regulamentação, de responsabilidades das empresas, de organizações públicas ${ }^{2}$ e, para o financiamento de pesquisas e desenvolvimento, por fornecer dados de extração de recursos naturais, pelo uso de energia e produção de emissões.

No âmbito empresarial, a ACV tem se consolidado como uma técnica para auxiliar na elaboração do planejamento estratégico, em projetos de produtos e,

\footnotetext{
${ }^{3}$ Também no Brasil verifica-se a incitativa do uso em órgãos públicos (Cf. TOSTA \& KIPERSTOK . 2005)
} 
entre outras inúmeras aplicações ${ }^{3}$, dar sustentação às reivindicações de rótulos de qualidade ambiental.

De acordo com CALDEIRA et. al (2005), os rótulos do tipo III, específicos para certificar as grandes transações comerciais business to business, e também aplicáveis a transações comerciais business to consumer, como no caso da eletricidade, são totalmente baseados na metodologia da ACV.

Embora a rotulagem ambiental não seja obrigatória no comércio mundial, já ocasiona uma diferenciação na competitividade dos produtos em um mercado cada vez mais exigente em termos de impactos ao meio ambiente. Por um lado, pela inibição imposta à penetração de produtos concebidos sem a devida ACV (ou com ACV que demonstre desvantagem ambiental) e, por outro, pelo fortalecimento competitivo dos produtos que já tenham rótulos ambientais baseados na ACV.

Desse modo, a importância da ACV vem se consolidando a medida em que a variável ambiental direciona as decisões de comando e controle do governo, do consumo da sociedade e de sustentabilidade das empresas. Mesmo no Brasil, em que esta ferramenta não se encontra tão difundida quanto nos diversos países da União Européia e da Ásia, já se observa uma preocupação dos representantes de indústrias, comércios e outras atividades neste sentido, pois a demanda diferenciada tem um forte potencial de inibir as exportações (Instituto Brasileiro de Informação em Ciência e Tecnologia - IBICT, 2005).

Portanto, a ACV no âmbito do desenvolvimento da tecnologia de Células a Combustivel no Brasil, pode auxiliar a melhorar o entendimento dos aspectos relacionados aos processos produtivos de uma forma ampla, identificando as oportunidades de melhoria das questões ambientais, avaliando a seleção de matéria-prima ou componentes feitos de diferentes materiais e, principalmente, subsidiando as estratégias de declaração ambiental. 


\section{4 - avaliação do ciclo de vida dA CÉlula A COMBUSTIVEL DE MEMBRANA TROCADORA DE PRÓTONS}

Na revisão da literatura específica verificou-se que os potenciais impactos associados à aplicação das células a combustivel têm sido, internacionalmente, bem documentados. Exemplos de estudos envolvendo as questões ambientais relacionadas à utilização da tecnologia de $\mathrm{CaC}$ podem ser encontradas em HART \& HORMANDINGER (1997), HART \& HORMANDINGER (1998), HART \& BAUEN (1998) e HAILES (1999). Entretanto, o mesmo não ocorre com aqueles relacionados à produção e destinação final. O primeiro passo neste sentido foi realizado recentemente por KARAKOUSSIS et. al. (2000), ao analisar os materiais e os fluxos de energia de sistemas de fabricação de $\mathrm{CaC}$, usando a ACV.

Posteriormente, considerando os méritos ambientais relativos à tecnologia $\mathrm{CaC}$, a crescente demanda do mercado de energia e o desenvolvimento das políticas regulatórias cada vez mais rígidas, PEHNT (2000a, 2000b, 2001, 2002, 2003); PEHNT \& RAMESOHI (2002) e HANDLEY et. al. (2002) dedicaram-se a avaliar a importância ambiental dos impactos associados a outras fases do ciclo de vida desse sistema. Contudo, no âmbito nacional, não se observa o direcionamento das pesquisas neste caso e, isto evidencia-se pela a ausência de publicações sobre o tema em debate.

Dentre os trabalhos publicados sobre a avaliação do ciclo de vida da PEMFC no estágio produtivo e de disposição final, destacam-se aqueles elaborados por PEHNT (2001) e HANDLEY et.al (2002), pois estes deram seqüência às abordagens e propostas de trabalhos futuros formulados KARAKOUSSIS et. al. $(2000)^{1}$, principalmente nos aspectos relacionados ao módulo. Desta forma, esses estudos são apresentados e discutidos em seqüência, no intuito de apontar o peso das questões ambientais da PEMFC para o desenvolvimento tecnológico, além de indicar uma direção para estudos no Brasil.

\footnotetext{
${ }^{1}$ Sendo o marco de referência para os estudos de ACV da manufatura da PEMFC, procurou-se descrevê-lo com mais detalhes do que os outros trabalhos também analisados neste capítulo. Contudo, em todos os estudos somente os dados pertinentes ao objetivo desta dissertação são discutidos.
} 
As informações aqui apresentadas restringiram-se ao principal componente do módulo de célula PEMFC, no caso o conjunto eletrodo membrana (MEA) e particularmente aos catalisadores de platina. Os dados dos demais elementos como placas bipolares e componentes auxiliares não foram contemplados, considerando o fato do atual centro de atenção em pesquisas encontrar-se no desempenho, durabilidade e custo das membranas poliméricas e dos catalisadores de platina utilizados nessa tecnologia (HANDLEY et. al, 2002).

\section{1 - Emissões Ambientais da SOFC e SPFC: sistema de produção e disposição final}

O trabalho Environmental Emissions of SOFC and SPFC ${ }^{2}$ System Manufacture and Disposal elaborado por KARAKOUSSIS et. al (2000) foi um dos primeiros estudos a avaliar os aspectos ambientais do sistema de manufatura de $\mathrm{CaC}$ e apontar, além da necessidade de uma investigação mais aprofundada do sistema produtivo, a estreita relação entre os custos do sistema e os aspectos ambientais.

O objetivo central do trabalho de Karakoussis e colaboradores, versou na construção do conhecimento sobre as emissões para o meio ambiente, gerado pelo sistema de produção da SOFC e PEMFC e, subseqüentemente, na identificação dos fatores chaves que poderiam representar uma barreira para competitividade comercial de cada sistema.

Embora, haja menção da análise da fase pós-uso das tecnologias estudadas, no período em que o estudo foi realizado não havia dados disponíveis para futuros cenários de gerenciamento da disposição final, de forma que apenas abordagens superficiais são realizadas sobre essa questão.

O inventário, em ambos os sistemas, concentrou-se no estágio de produção, utilizando um banco de dados ambientais para a entrada de materiais no processo de produção e, a etapa produtiva, também incluiu o processamento da matéria prima. As fases em uso não foram relevadas, pois já haviam sido

\footnotetext{
2Para fins de padronização da nomenclatura a sigla adotada será a PEMFC.
} 
investigadas e documentadas como parte de dois estudos anteriores da ETSU sobre $\mathrm{CaC}$. No caso da PEMFC, o estudo está direcionado para a fabricação de dois módulos da tecnologia da Ballard, sendo um móvel produzido em parceria com Daimler Chrysler e Ford, e o outro oriundo de uma planta de cogeração estacionária desenvolvido em parceria com a Alston e outras empresas. A FIG.

4.1 apresenta o ciclo de vida de um sistema de célula a combustivel.

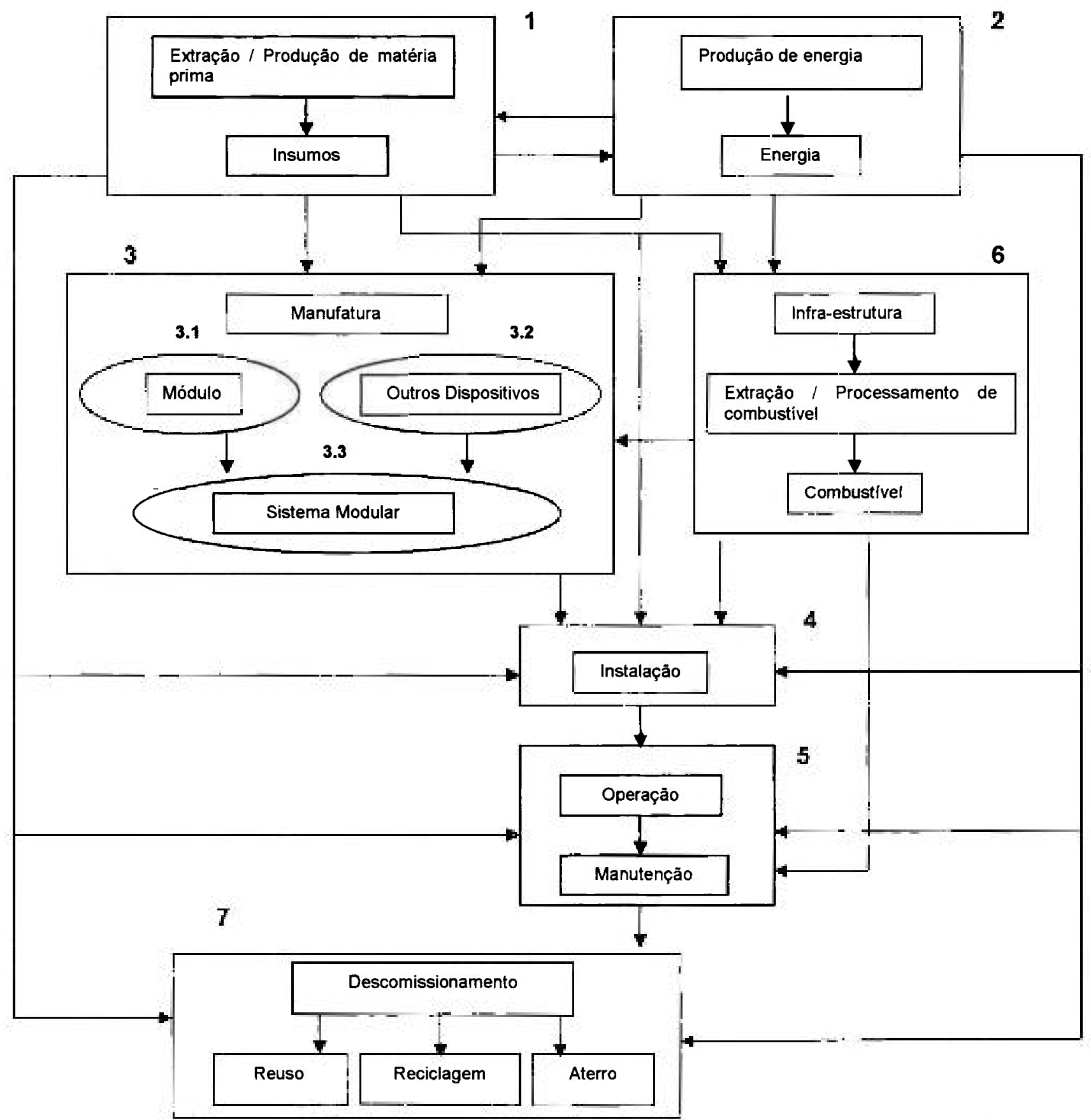

FIGURA 4.1 - Diagrama conceitual do ciclo de vida de um sistema CaC em 7 estágios. Fonte: KARAKOUSSIS et.al. (2000), modificado por FUKUROZAKI (2006) 
No ciclo de vida da PEMFC, o foco do estudo concentrou-se nas fases 3.1, 3.2 e 3.3. Quando possível, os dados de materiais relevantes e entradas de energia dos processos nos estágios 1 e 2 foram coletados e inclusos no inventário. Por exemplo, fatores de emissões para as entradas de energia nas etapas 2 e 3 podem ser baseadas no ciclo de vida do combustivel, e neste sentido, entre outros aspectos, para as emissões associadas à produção de módulo e outros dispositivos.

Questões ambientais das fases 5 e 6 não foram abordadas, pois, estas foram bem investigadas em trabalhos anteriores (HART \& HORMANDINGER, 1997; HART \& BAUEN, 1998). Devido à atual incerteza dentro da indústria no que se refere ao provável gerenciamento da disposição final do sistema, a etapa 7 é apresentada apenas com uma direção qualitativa. Dada a limitação inicialmente estabelecida para a análise dos estudos realizados internacionalmente, somente às informações relativas à fabricação do MEA são apresentadas nesta dissertação, incluindo desta forma, a produção dos eletrodos e da membrana eletrolítica.

\subsection{1 - Sistema PEMFC}

As células de Membrana Trocadora de Prótons são produzidas de muitas maneiras e por diversas empresas e organizações de pesquisa. A vasta maioria do sistema de PEMFC é projetada e desenvolvida para teste (KAROUKISSIS e colaboradores, 2000). Durante os últimos cinco anos o número de companhias produzindo componentes ou sistemas de PEMFC têm crescido rapidamente, contudo, somente algumas estão conduzindo o campo da pesquisa e, em relação ao estado da arte há poucos líderes com perspectiva comercial.

No rol dessas empresas, a Ballard Power Systems tem sido reconhecida como a condutora do conhecimento em relação ao desenvolvimento de módulos e testes de protótipos em escala real no mundo, incluindo a produção para geração estacionária e automotiva, o que sugere a disponibilidade de algumas informações em termos de componentes e possiveis métodos de produção. Neste sentido, dois sistemas foram escolhidos, uma aplicação móvel e outra 
estacionária, ambos baseados no módulo da Ballard. Para a aplicação móvel selecionou-se um módulo de geração usado atualmente no carro da Daimler Chrysler Necar 4, com uma potência nominal de $70 \mathrm{~kW}$, enquanto que na aplicação estacionária optou-se por um sistema combinado de energia e calor de $250 \mathrm{~kW}$ desenvolvido em parceria com a Alstom.

O módulo, projetado tanto para a aplicação móvel quanto para a estacionária, caracteriza-se por um grupo de células unitárias, em série e em quantidade suficiente para produzir a voltagem exigida em cada sistema. Ressalta-se que os dois módulos aplicados em diferentes setores de geração, utilizam a mesma tecnologia e, portanto exibem caracteristicas similares em termos de consumo de energia, materiais e emissões ambientais, o que torna desnecessário a descrição detalhada de um sistema do outro ${ }^{3}$.

\subsection{2 - Processo Produtivo do MEA}

Os elementos do MEA compõem o coração do sistema de células a combustivel e o nível de detalhamento usado na análise da sua fabricação contemplou a descrição das entradas e as saidas de todos os passos individuais de cada processo. Apresenta-se a seguir um resumo do processo produtivo e o diagrama de fluxo da produção (FIG. 4.2).

a) Tinta: os catalisadores de Pt e Ru, ancorados em carbono, são adicionados a uma solução de Nafion, contendo $\mathrm{H}_{2} \mathrm{O}$ destilada e um solvente (álcool alifático).

b) Eliminação de solventes orgânicos e redução da viscosidade: a tinta é aquecida para eliminação dos solventes orgânicos por evaporação. Posteriormente, adiciona-se água ara manter um volume constante. Uma vez que todos os solventes orgânicos são volatilizados a solução é aquecida novamente para reduzir a viscosidade.

c) Impressão (screen printed): a tinta catalítica é "impressa" em quantidadès necessárias sobre o Carbon Paper $^{4}$ para formar o eletrodo negativo e positivo.

\footnotetext{
Basicamente, as principais diferenças entre as duas aplicações no que tange ao MEA são a espessura da membrana e a quantidade de eletrocatalisador utilizados.

${ }^{4}$ Papel de fibra de carbono rígida preteflonada.
} 
d) Secagem: a água remanescente dos eletrodos é eliminada em um equipamento conhecido como tunnel dryer (secadora).

e) Corte dos eletrodos: os eletrodos constituidos de Carbon Paper e catalisador são cortados na forma e tamanhos desejados.

f) Montagem dos eletrodos na membrana eletrolitica: a membrana polimérica Nafion® é colocada sob pressão entre os dois eletrodos previamente cortados, em uma temperatura de transição vitrea do Nafion ${ }^{\circledR}$.

g) Corte final do MEA: o conjunto eletrodo membrana prensado é cortado na forma e tamanho desejado.

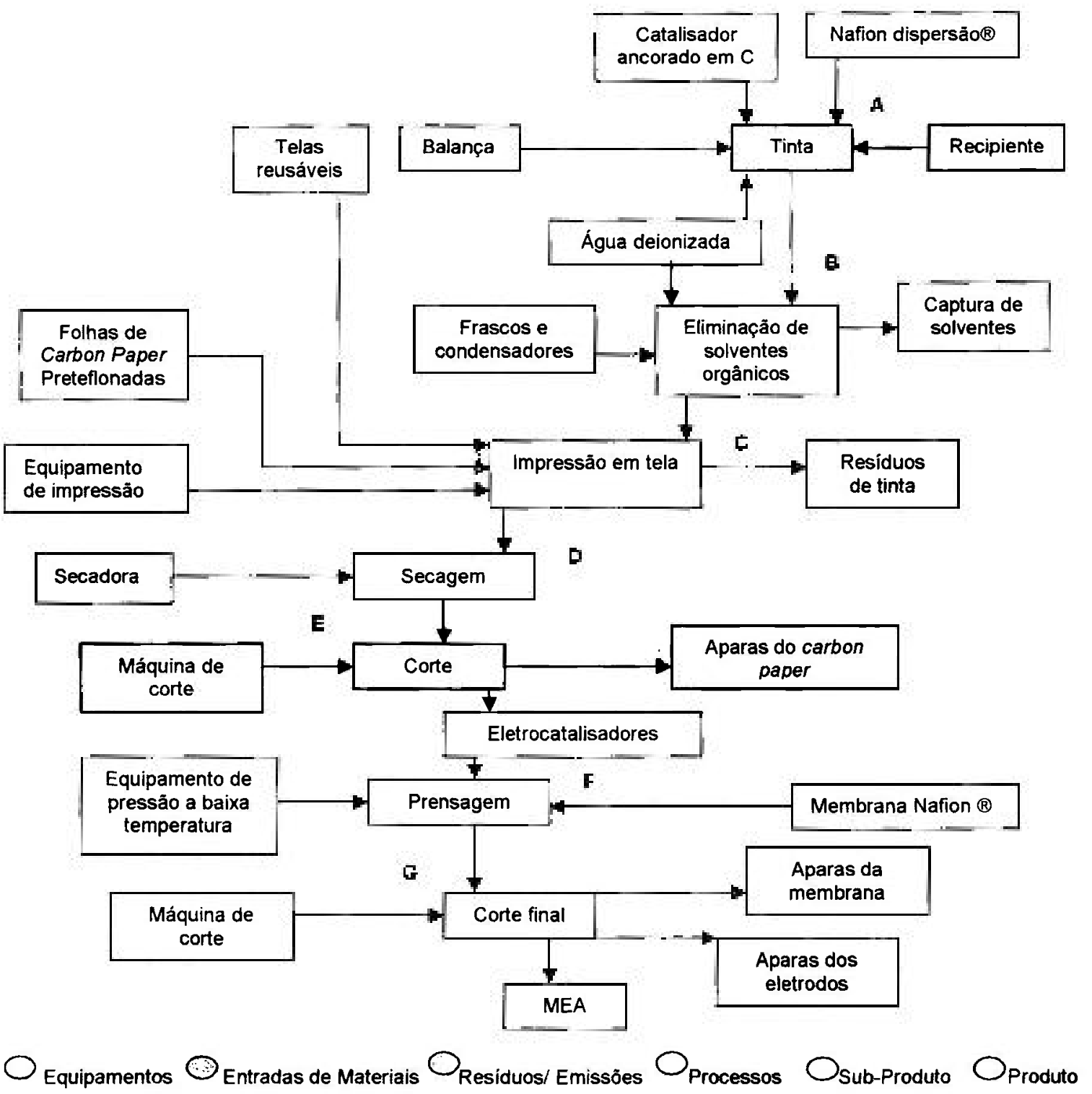

FIGURA 4.2 -Diagrama do fluxo de produção do MEA.

Fonte: KARAKOUSSIS et.al. (2000), modificado por FUKUROZAKI (2006) 


\subsection{3 - Inventário}

A quantidade dos principais materiais do MEA e os requerimentos de energia elétrica para a manufatura de cada um destes são apresentadas na TAB. 4.1, na qual é possível identificar que a platina apresenta o valor mais significativo de requisição de energia para a produção em função da quantidade.

TABELA 4.1 - Quantidade dos principais materiais e os requerimentos em termos de energia.

\begin{tabular}{|c|c|c|c|c|c|c|c|c|}
\hline Materials & Pt & $\mathbf{R u}$ & Carbono & $\begin{array}{l}\text { Carbon } \\
\text { Paper }\end{array}$ & $\begin{array}{c}\text { Nafíon } \\
\text { Membrana }\end{array}$ & $\begin{array}{c}\text { Nafion } \\
\text { Dispersăo }\end{array}$ & Isopropanol & $\begin{array}{c}\text { Água } \\
\text { deionizada }\end{array}$ \\
\hline $\begin{array}{c}\text { Quantidade } \\
\text { requerida } \\
\text { (kg/kW) }\end{array}$ & 0,83 & 0,21 & 1,25 & 62,36 & 79,82 & 0,65 & 9,52 & 6,14 \\
\hline $\begin{array}{l}\text { Energia } \\
\text { Produção } \\
\text { (MJ/kW) }\end{array}$ & 164 " & 41348,37 & 501,71 & $87.310,00$ & 1141,49 & 9,16 & 497,84 & 0,12 \\
\hline
\end{tabular}

Fonte: KARAKOUSSIS et.al. (2000), modificado por FUKUROZAKI (2006)

Para os processos nos quais estes materiais são utilizados na fabricação do MEA da PEMFC, as exigências de eletricidade são ilustradas na TAB. 4.2, onde observa-se que o maior consumo de energia está relacionado à etapa de eliminação de solventes orgânicos da tinta catalítica.

TABELA 4.2 - Entrada de energia para cada processo de produção do MEA.

\begin{tabular}{c|c|c|c|c|c|c|c}
\hline Processi * $^{*}$ & A & B & C & D & E & F & G \\
\hline $\begin{array}{c}\text { Energia } \\
\text { (MJ/kW) }\end{array}$ & 0,02 & i. i & 0,05 & 0,03 & 0,03 & 0,15 & 0,03 \\
\hline
\end{tabular}

Fonte: KARAKOUSSIS et.al. (2000), modificado por FUKUROZAKI (2006)

Os efeitos resultantes no meio ambiente e no desenvolvimento da PEMFC, relativos ao consumo de energia na produção dos materiais e fabricação do MEA, estão diretamente relacionados a matriz energia elétrica de cada pais. Portanto, os valores apresentados nas tabelas acima. podem representar uma maior ou menor significância, dependendo deste tipo de matriz e seus respectivos impactos e custos totais. 
Quanto às saidas dos processos do sistema produtivo do MEA estas constituem, além do próprio produto, nas perdas dos materiais usados na fabricação (TAB. 4.3), bem como nas emissões ambientais (residuos, efluentes e emissões atmosféricas) procedentes de cada fase de produção. As perdas durante o processo podem ser considerados por dois parâmetros: desperdícios de materiais e rejeitos oriundos de produtos defeituosos ${ }^{5}$.

TABELA 4.3 - Perdas de materiais no processo de produção do MEA.

\begin{tabular}{|c|c|c|}
\hline Materiais utilizados nos processos & Uso (\%) & Perdas $(\%)$ \\
\hline Platina & 98,0 & $1-2$ \\
\hline Rutênio & 98,0 & $1-2$ \\
\hline Água Deionizada $^{1}$ & 93,7 & 16,3 \\
\hline Nafion Dispersãoß & 93,7 & 16,3 \\
\hline Carbono & 98,0 & 2 \\
\hline Tinta Catalítica & 90,0 & 10 \\
\hline Carbon Paper & 92,5 & $7,5^{*}$ \\
\hline Membrana Nafion(8) & 95,0 & $5^{*}$ \\
\hline Áqua Deionizada ${ }^{2}$ & 99.9 & 0.01 \\
\hline
\end{tabular}

Fonte: KARAKOUSSIS et.al. (2000), modificado por FUKUROZAKI (2006)

No que diz respeito às emissões para o meio ambiente, estas foram divididas em três categorias: ar, água e solo. Dada a relativa importância da platina no consumo de energia para a produção do MEA e principalmente para a tecnologia PEMFC, optou-se por apresentar aqui, de forma detalhada, somente as saídas relacionadas às emissões para o meio ambiente deste catalisador (TAB. 4.4). Os parâmetros das emissões para o solo não apresentaram valores.

Embora o MEA da PEMFC apresente, em ambas as aplicações, a utilização de materiais e processos iguais para a produção do conjunto eletrodo membrana, as quantidades necessárias para a fabricação dos módulos alteram o valor, além do consumo de energia, das emissões globais no sistema.

\footnotetext{
${ }^{5}$ No estudo de KARAOUKISSIS et. al. (2000), os dados sobre as perdas são destacados no inventário. porém cabe salientar que essas também são entendidas como residuos.
} 
TABELA 4.4 - Emissões para o meio ambiente da produção de platina ${ }^{6}$.

\begin{tabular}{|c|c|c|c|}
\hline \multicolumn{4}{|c|}{ Platina } \\
\hline Emissōes para 0 ar & $\mathbf{m g} / \mathbf{k W}$ & Emissões para água & $\mathbf{m g} / \mathbf{k W}$ \\
\hline Partículas & $1,13 E+07$ & DQO & $6,49 E+04$ \\
\hline $\mathrm{CO}$ & $6,82 E+06$ & DBO & $2,02 E+04$ \\
\hline $\mathrm{CO}_{2}$ & $1,07 \mathrm{E}+11$ & Acido $(\mathrm{H}+)$ & $6,66 E+02$ \\
\hline SOX & $3,18 E+09$ & Sólidos Dissolvidos & - \\
\hline NOX & $1,77 \overline{E+07}$ & Hidrocarbonetos & $4,78 E+03$ \\
\hline Hidrocarbonetos & $3,72 E+07$ & $\mathrm{NH}_{4}$ & $2,36 E+04$ \\
\hline $\mathrm{H}_{2} \mathrm{~S}$ & $2,22 E+04$ & Sólidos em Suspensão & $1,52 E+06$ \\
\hline $\mathrm{HCl}$ & $2,18 E+06$ & Metais & $4,31 E+07$ \\
\hline $\mathrm{HF}$ & $3,07 E+05$ & $\mathrm{NO}^{-3}$ & $1,50 E+05$ \\
\hline Metais & $2,85 E+06$ & Formas de Nitrogênios & $1,65 E+01$ \\
\hline Aromáticos-HC & $7,65 E+04$ & $\mathrm{ClO}^{-3}$ & - \\
\hline $\mathrm{CFC} / \mathrm{HCFC}$ & ---- & Fosfato as $\mathrm{P}_{2} \mathrm{O}_{5}$ & $5,26 E+0,5$ \\
\hline VOC & $3,56 E+04$ & Detergente/ Óleo & $2,45 E+0,5$ \\
\hline$\overline{-\cdots}$ & $\ldots$ & Orgânicos dissolvidos & - \\
\hline--- & - & Outros Orgânicos & $1,21 E+07$ \\
\hline מהמה & $\ldots$ & $\mathrm{Cr}, \mathrm{F}^{-}$ions & $5,82 E+07$ \\
\hline$\overline{---}$ & - & $\mathrm{SO}^{-4}$ & $4,22 E+07$ \\
\hline
\end{tabular}

Fonte: KARAKOUSSIS et.al. (2000), modificado por FUKUROZAKI (2006)

$\mathrm{Na}$ TAB. 4.5, na qual é apresentando o total de emissões de cada compartimento ambiental resultantes da produção do MEA, observa-se que os valores para a aplicação estacionária é maior que a móvel. Desta forma, é nítido que qualquer requerimento de material tem seu efeito equivalente no ambiente.

TABELA 4.5 - Total de emissões para o meio ambiente na produção do MEA.

\begin{tabular}{c|c|c}
\hline MEA & Aplicação estacionária (250 kW) & Aplicação móvel (70 kW) \\
\hline Total das emissões para o ar & $2,53 \mathrm{E}+15 \mathrm{mg} / \mathrm{kW}$ & $7,09 \mathrm{E}+14 \mathrm{mg} / \mathrm{kW}$ \\
\hline Total das emissões para a água & $4,95 \mathrm{E}+10 \mathrm{mg} / \mathrm{kW}$ & $1,39 \mathrm{E}+10 \mathrm{mg} / \mathrm{kW}$ \\
\hline Total das emissóes para o solo & $4,64 \mathrm{E}+06 \mathrm{mg} / \mathrm{kW}$ & $1,30 \mathrm{E}+06 \mathrm{mg} / \mathrm{kW}$ \\
\hline
\end{tabular}

Não obstante, em muitos casos, também a ineficiência do processo ${ }^{7}$ pode produzir emissões adicionais e, até mesmo no caso dessas emissões não representarem um peso para as questões ambientais, o custo das crescentes perdas podem representar uma barreira para a inserção da PEMFC no mercado. Um exemplo atual do custo equivalente de pequenas e crescentes perdas de platina, considerando a ausência de reciclagem e recuperação é ilustrado na TAB. 4.6. O preço considerado foi de $\$ 1321,00 / 0,03 \mathrm{~kg}$ (MATTHEY, 2006).

\footnotetext{
"Ressalta-se que a fonte utilizada foi o banco de dados da Team Software.

Diretamente relacionado ao projeto, as especificações dos equipamentos e métodos utilizados.
} 
TABELA 4.6 - Custo das perdas de platina.

\begin{tabular}{c|c|c|c}
\hline \multirow{3}{*}{ Entrada de Material $\mathbf{( g / k W )}$} & Perda de material no processo & Perdas por ano $\mathbf{( k g )}$ & Custo (\$) \\
\hline \multirow{3}{*}{0,83} & 7,4 & 173 & 228533,00 \\
\cline { 2 - 4 } & 8,4 & 196 & 258916,00 \\
\cline { 2 - 4 } & 12,4 & 290 & 383090,00 \\
\hline
\end{tabular}

Com base nos dados da TAB. 4.6, é evidentemente clara a importância da recuperação e reciclagem de platina, pois esses procedimentos podem proporcionar uma diminuição dos requerimentos de material e reduzir significativamente o custo da produção.

A recuperação da platina desperdiçada durante o processo e a reciclagem do catalisador de células desativadas é uma das principais questões das quais os produtores de $\mathrm{CaC}$ e empresas recicladoras de metais preciosos têm se preocupado e visualizado como uma oportunidade de negócio no setor, pois a tendência de uso da ACV para a rotulagem de produtos e a internalização das externalidades ambientais (por exemplo, taxas de carbono) poderá elevar o custo deste material no futuro.

Em geral, os incentivos para a otimização dos processos e materiais com base nas questões ambientais caminham na mesma direção que outras pressões comerciais para reduzir a complexidade do sistema de produção e custo, pois muitos dos materiais e processos são relativamente caros. Portanto, as barreiras comerciais oriundas dos aspectos ambientais podem em muitos casos dirigir a antecipação do desenvolvimento de processos.

\subsection{4-Análise do Inventário e Consideracões sobre o Estudo}

Conforme mencionado anteriormente, o estudo das Emissões Ambientais da SOFC e PEMFC não contemplou a avaliação dos impactos ambientais e desta forma, a classificação e caracterização das emissões em impactos no meio ambiente. A partir dos dados inventariados observa-se que as emissões dos materiais oriundos da produção do MEA, por exemplo, a platina, apresenta 
parâmetros $\left(\mathrm{NO}_{x} \mathrm{H}_{2} \mathrm{~S}, \mathrm{Pt}_{1} \mathrm{Cl}^{-}\right.$e $\left.\mathrm{F}^{-}, \mathrm{DQO}, \mathrm{DBO}, \mathrm{P}_{2} \mathrm{O}_{5}\right)$ que podem significar potenciais impactos à saúde humana, água, biota e camada de ozônio.

Entretanto, os impactos ambientais são fortemente relacionados à concentração de uma emissão ou poluente especifico no meio receptor, bem como da localização da sua ocorrência em termos geográficos (local, regional, global). Sem uma análise aprofundada não é possivel identificar o quanto às emissões relacionadas à produção do MEA são significativas no contexto ambiental.

Portanto, a avaliação dos impactos deve ser considerada seriamente para subsidiar as declarações relacionadas às vantagens ambientais da tecnologia de $\mathrm{CaC}$. Ainda, os desperdícios e rejeitos do processo produtivo do MEA estão intimamente relacionados a entradas de materiais e, estes por sua vez, ao consumo de energia e emissões.

Todos estes aspectos podem direcionar para uma elevação dos custos do sistema, na medida em que têm sua importância apoiada na crescente ênfase das políticas regulatórias (padrões de emissões para o ar, água e solo) e de mercado na avaliação do ciclo de vida (rotulagem ambiental), na tendência de internalização dos custos ambientais em muitos paises e, no potencial fornecimento dos materiais.

Desta maneira, as considerações relevantes para o desenvolvimento dos estudos posteriores dizem respeito à avaliação e caracterização dos impactos produzidos pelas emissões na etapa de fabricação, assim como nos cenários de recuperação e reciclagem dos materiais utilizados, durante a produção e também após o consumo.

Assim sendo, apresenta-se a seguir uma sintese dos estudos desenvolvidos por PEHNT (2001) e HANDLEY et. al (2003), que caminharam no sentido de equacionar estas questões e produziram um avanço da construção do conhecimento iniciado por KARAKOUSSIS et. al (2000). Não serão apresentadas descrições detalhadas desses estudos, como realizado anteriormente, somente os resultados obtidos e respectivos julgamentos que representam o interesse geral deste capítulo. 


\section{2 - Avaliação do Ciclo de Vida de Módulos de Células a Combustível}

No estudo Life cycle assessment of fuel cell stacks realizado por PENHT (2001), o objeto de análise da ACV eram dois módulos da PEMFC, também produzidos pela Ballard, de aplicação móvel $(75 \mathrm{~kW})$ e outra estacionária (275 kW). O objetivo da avaliação visava, principalmente, determinar a importância relativa da produção do módulo comparado-o com a sua fase de utilização, bem como os potenciais aperfeiçoamentos ou possiveis limitações em relação a sua produção.

Embora existem diferenças, entre o banco de dados utilizados para a análise do inventário e os módulos em termos de produção de energia, estudados por KARAKOUSSIS et. al (2000), PENHT (2001) avançou no sentido de caracterizar e quantificar as emissões oriundas do processo produtivo em impactos ambientais e, ao prover informações para o possivel aperfeiçoamento dos sistemas de produção.

Desta forma, os resultados obtidos no estudo indicaram que apesar da PEMFC apresentar, durante o uso, vantagens ecológicas em função dos baixos indices de emissão de gases do efeito estufa, o que é especialmente importante para áreas urbanas com condições ambientais severas, a etapa produtiva, especificamente do MEA, possui impactos que não podem ser negligenciados quando comparados à sua utilização.

Estes impactos são causados principalmente pelo uso de metais do grupo da platina (PGM) como catalisadores e estão relacionados ao processo de extração pirometalúrgica, alocação das diferentes emissões e a sustentabilidade de produção dos paises fornecedores. Com base nesses resultados, na etapa de melhorias, a principal rota identificada foi à reciclagem ${ }^{8}$ dos catalisadores do MEA, pois, além de reduzir significativamente as emissões responsáveis pelo aquecimento global e acidificação durante a fase de produção da PEMFC, se

\footnotetext{
"Através do mesmo processo de reciclageın dos catalisadores utilizados nos atuais veículos automotivos.
} 
constituem em um requisito econômico apoiado por medidas ou organizações legais para a futura produção de módulos da PEMFC.

Portanto, os resultados alcançados por PEHNT (2001) evidenciam a importância do uso da ferramenta ACV no contexto econômico e ambiental da tecnologia PEMFC, direcionando cada vez mais para a investigação minuciosa de todo o seu ciclo de vida e, paralelamente para a identificação de etapas e processos que devem ser aperfeiçoados para alcançar sua sustentabilidade. Desta forma, o estudo apresentando a seguir, adianta-se no sentido de prover informações e métodos para o gerenciamento do estágio final do ciclo de vida PEMFC.

\section{3 - Impactos da Legislação de Resíduos Veiculares na União Européia: opções de fim de vida para as células de eletrólito polimérico}

$\mathrm{Na}$ análise do fim de vida de um módulo de $70 \mathrm{~kW}$ da célula PEMFC inserida no trabalho Impact of the European Union vehicle waste directive on end of life options for polymer electrolyte fuel cells realizado por Handley et. al (2002), o foco primordial constituiu na construção dos possivveis cenários e as estratégias a serem adotadas para o gerenciamento pós-consumo do módulo, com base na legislação da União Européia para resíduos de veículos.

Sob o enfoque da ACV, foram construídos cenários, para cada componente do módulo (MEA, placas bipolares e componentes auxiliares), considerando as alternativas do que é ambientalmente mais adequado, em função dos prováveis impactos dos residuos da aplicação móvel desta tecnologia, seguindo desta forma, a seguinte hierarquia: reuso, reciclagem, incineração com recuperação de energia e disposição em aterros.

Diante das diretivas legais da União Européia, concomitantes a ponderações sobre a viabilidade técnica, econômica e ambiental existentes, os resultados alcançados indicaram que a gama de pressões externas influenciando a escolha de uma estratégia de gerenciamento de fim de vida satisfatória e as 
oportunidades de reuso dos componentes são limitados. Portanto e a princípio, a reciclagem é a melhor opção para o estágio final da PEMFC.

Ressalta-se que no estudo que todos os componentes separadamente podem ser reciclados e, no caso dos catalisadores de platina, HANDLEY et. al (2002) relata que é possivel recuperá-la com alto rendimento utilizando um método de extração por solventes. Também, segundo esse autor enfatiza, além das razões econômicas, o argumento ambiental para a reciclagem da platina é forte, pois em comparação a produção a partir de fontes primárias, as emissões de dióxido de enxofre $\left(\mathrm{SO}_{2}\right)$ podem ser diminuidas por um fator igual a 100 e a demanda de energia primária por um fator 20 .

Neste quadro, constata-se mais firmemente a relevância dos estudos em ACV da PEMFC, no âmbito do desenvolvimento sustentável e para o desenvolvimento tecnológico deste sistema de energia, pois a construção de cenários de disposição final com base na avaliação do ciclo de vida desta etapa destacou que as alternativas e possiveis métodos de aperfeiçoamento do sistema devem ser desenvolvidos também para atender as necessidades legais e ambientais de cada pais, região ou local.

\section{4 - Análise Geral dos estudos sobre a Avaliação do Ciclo de Vida da PEMFC}

Inicialmente, ressalta-se que as análises aqui apresentadas não se ativeram às particularidades de cada estudo e, desta forma, a uma avaliação comparativa dos sistemas da PEMFC, já que o objetivo, a unidade funcional, o escopo, softwares, banco de dados do inventário, entre outros, são diferentes. Neste contexto, evidencia-se apenas o desenvolvimento das pesquisas sobre a tecnologia PEMFC, sob o enfoque da abordagem metodológica e do uso da ACV.

Diante deste panorama, observou-se nos estudos analisados, que a platina é um dos principais contribuintes em termos de impactos ambientais durante a fase de manufatura da tecnologia PEMFC. Somados aos significativos efeitos deteriorantes no meio ambiente, está o alto custo deste metal nobre e o fato de 
constituir-se, atualmente, no catalisador mais viável para o sistema de energia PEMFC. Neste sentido, a reciclagem de platina surge como uma alternativa para mitigar os impactos ao mesmo tempo em que proporciona uma redução dos custos do sistema.

Não obstante, verifica-se que as questões ambientais e econômicas relacionadas a PEMFC caminham juntas $e$, os meios para equacioná-las encontram-se na utilização de métodos que propiciam as informações necessárias para tal. Portanto, a ACV desta tecnologia durante a fase de manufatura e pós-vida útil demonstrou ser eficiente para os propósitos estabelecidos nos estudos apresentados e, ainda, apontou caminhos a serem desenvolvidos e avaliados para atingir a sustentabilidade desse sistema de energia. 


\section{5- DESENVOLVIMENTO E ANÁlise dO PROCESSO DE RECUPERAÇÃO DOS CATALISADORES DE PLATINA DA PEMFC}

\section{1 - Rota Experimental}

No capitulo anterior, a reciclagem da platina foi apresentada como alternativa para minimizar os impactos ao meio do ambiente, durante a fase de produção da PEMFC, no entanto, os métodos citados por PEHNT (2001) e HANDLEY et. al. (2002) não são específicos para a recuperação e reciclagem deste metal nobre utilizado na fabricação do MEA.

Segundo ROBERTSON (2003), os métodos convencionais para a reciclagem de platina, nos quais são utilizados solventes ácidos e processos pirometalúrgicos, apresentam baixa taxa de recuperação da platina do conjunto eletrodo membrana da PEMFC. Não obstante, estes processos também podem resultar na emissão de um gás tóxico e corrosivo, no caso HF, devido ao fato das partículas de platina serem recobertas por uma dispersão perfluorada (comumente a Nafion $囚$ ).

Desta forma, procurou-se identificar na literatura estudos especificos sobre métodos de reciclagem da platina da PEMFC. Contudo, somente duas técnicas de recuperação que ainda se encontram em desenvolvimento foram encontradas, essas são descritas em GROT et. al (2004) e SHORE \& ROBERTSON (2004).

Face a este quadro, buscou-se desenvolver um processo de recuperação de platina dos MEA's produzidos no Instituto de Pesquisa Energéticas e Nucleares, que atendesse concomitamente os aspectos relacionados a impactos ambientais e aos requisitos necessários para a sua reciclagem primária'. Para tanto, as propostas encontradas na pesquisa bibliográfica serviram como base direcionar o método de recuperação desenvolvido no IPEN (FIG. 5.1).

\footnotetext{
${ }^{1}$ Definida como a reciclagem do residuo dentro do mesmo processo que a originou (JOHN, 2001).
} 


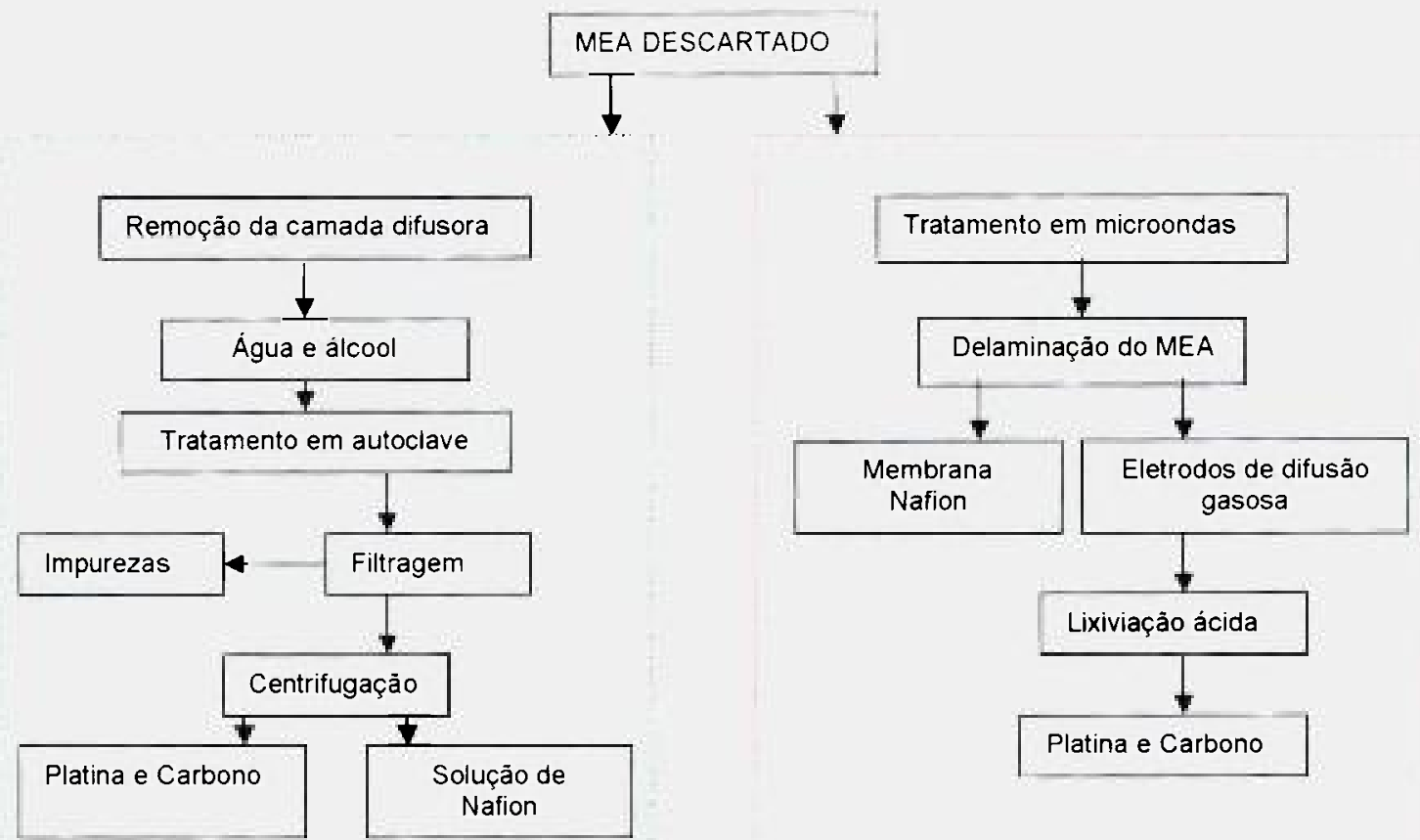

GROT et. al. (2004)

SHORE \& ROBERTSON (2004)

FIGURA 5.1 - Propostas de recuperação da platina do MEA da PEMFC, encontradas na literatura.

Como os processos não estão consolidados e não há informações detalhadas de todas as etapas das propostas, optou-se por selecionar a rota que apresentava menor complexidade, neste caso, o caminho escolhido foi o sugerido por GROT et. al. (2004). Porém, considerou-se também que o procedimento abordado por SHORE \& ROBERTSON (2004) envolve duas atividades nas quais constata-se a liberação de HF, são elas: tratamento em microondas e lixiviação ácida.

Subseqüentemente, a próxima fase caracterizou-se na coleta de MEA de células desativadas. Entretanto, este componente da PEMFC é produzido em escala laboratorial, o que dificultou a obtenção de uma quantidade significativa para análise, limitando-se assim a 23 unidades. Neste sentido, salienta-se o caráter exploratório e as restrições deste estudo em função da quantidade de material disponivel. Os MEA's obtidos foram numerados de acordo com as suas características (TAB. 5.1) 
TABELA 5.1 - Caracteristicas do MEA

\begin{tabular}{l|c|c}
\hline \multirow{2}{*}{ COMPONENTE } & \multicolumn{2}{|c}{ ÁREA ATIVA 25 CM ${ }^{2}$} \\
\cline { 2 - 3 } & MEA 01-15 & MEA 16-23 \\
\hline Eletrólito & Membrana Nafion@ 105 & Membrana Nafion@ 105 \\
\hline Camada Difusora & Carbon Cloth EC-CC1-060T & Carbon Paper EC-TP1-060T \\
\hline Camada Catalítica & Platina E-TEK 20 & Platina E- TEK 20 \\
\hline
\end{tabular}

$\mathrm{Na}$ TAB. 5.1 verifica-se que 15 unidades apresentavam como camada difusora o Carbon Cloth e 8 o Carbon Paper - Papel Toray, sendo os demais componentes com especificações iguais. Segundo BALDO (2003), o desempenho, relacionado à densidade de corrente, dos MEA's com a camada difusora de tecido de carbono são superiores ao do papel carbono. Por conseguinte, e visto a disponibilidade de amostras, somente o conjunto eletrodo membrana que apresentava o Carbon Cloth foram utilizados para o processo de recuperação.

Nessa etapa preliminar apenas três MEA's do grupo que apresentava o tecido de carbono como camada difusora foram separados somente para testar a viabilidade de execução da rota escolhida. O procedimento experimental foi realizado no laboratório de componentes do Centro de Tecnologia de Materiais CCTM e, os experimentos efetuados em béquer de teflon de capacidade volumétrica de $200 \mathrm{~mL}$.

Primeiramente, as camadas difusoras foram separadas do conjunto eletrodo membrana manualmente $e$, as membranas, impregnadas com a camada catalítica, imersas em uma solução contendo água destilada e um solvente (álcool etílico pa) na relação $1: 1$, sendo o volume arbitrado de $50 \mathrm{~mL}$. Durante essa atividade, verificou-se a rápida e imediata ocorrência da remoção da camada catalítica, constatando que não havia necessidade de levar estes componentes para o tratamento na autoclave.

Desta forma, observou-se que no intervalo de trinta minutos ${ }^{2}$ a membrana pode ser totalmente retirada deste meio sem necessidade de realizar qualquer

${ }^{2}$ Este período foi estabelecido a partir da verificação de perda da integridade física da membrana quando mantida em solução por tempo superior a 30 minutos, o que dificulta a sua remoção da solução. 
processo de filtragem e centrifugação, sendo a solução residual, tal como observado em GROT et. al (2004), semelhante à tinta catalítica. A reprodutibilidade dos experimentos foi confirmada através da triplicata do mesmo.

A etapa seguinte constituiu-se na remoção da água e do solvente por aquecimento sem agitação, utilizando uma placa agitadora-aquecedora, a uma temperatura variando entre $30^{\circ} \mathrm{C}$ e $80^{\circ} \mathrm{C}$, pelo período necessário para a completa eliminação da fase líquida. Um diagrama do processo de recuperação encontra-se ilustrado na FIG. 5.2.

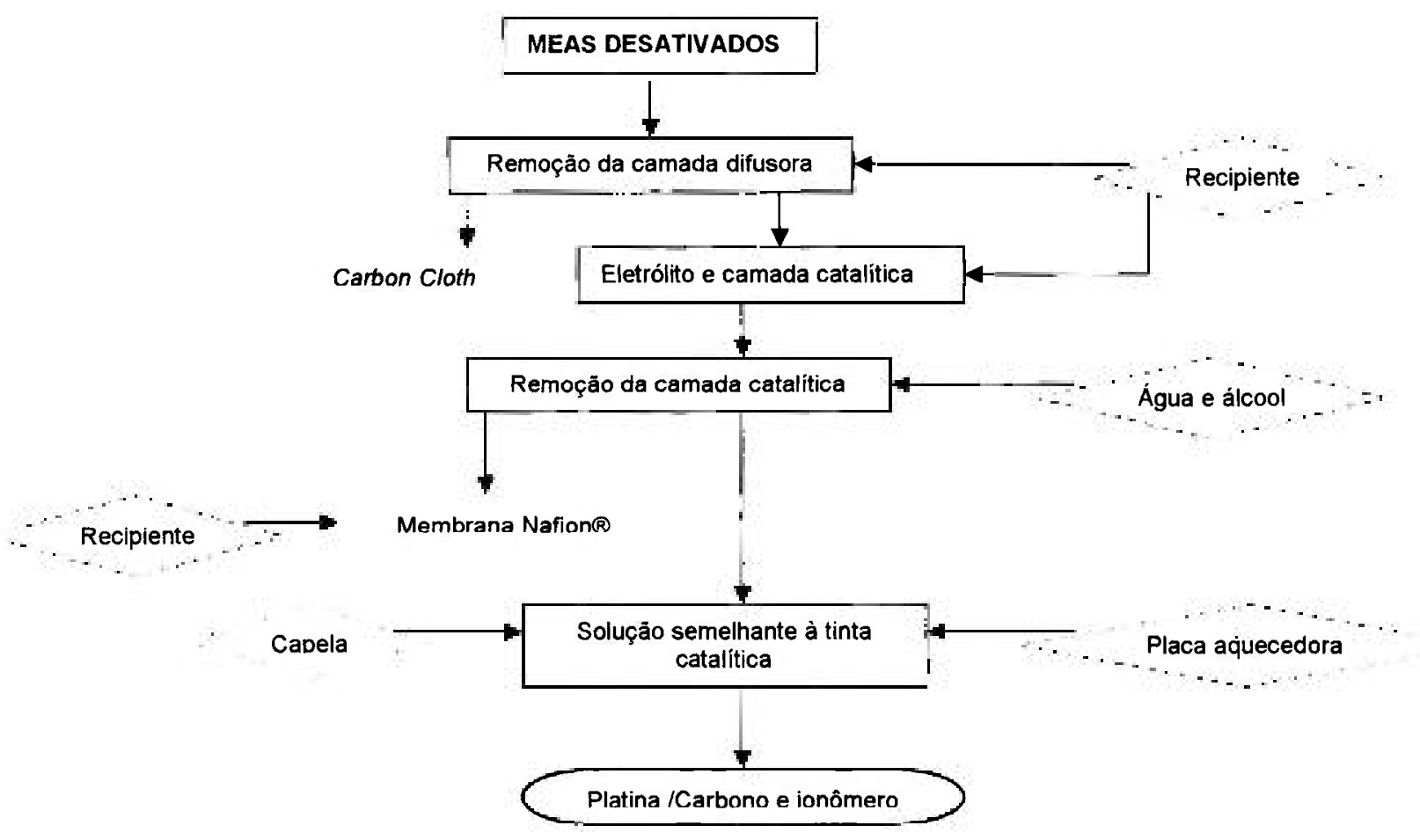

FIGURA 5.2 - Diagrama simplificado do procedimento experimental

Posteriormente, o soluto resultante foi removido do béquer com uma espátula e encaminhado para avaliação do teor de carbono pela perda de massa via Análise termogravimétrica - $\mathrm{ATG}^{3}$. Para fins de comparação, também foram encaminhadas para essa análise, amostras da platina comercial E-TEK 20 e da tinta catalítica utilizada no MEA do IPEN (na forma de pó). Destaca-se que não

\footnotetext{
${ }^{3}$ Descrita adiante, no item 5.2.1 Inventário
} 
foi avaliada a taxa de recuperação, pois o objetivo nesta fase, conforme citado anteriormente, era verificar a viabilidade de execução do método.

Os dados obtidos na análise termogravimétrica da platina recuperada e da tinta catalítica apresentaram porcentagens similares de perda de massa e coerentes com a platina comercial. Desta forma, verificou-se que, à princípio, este procedimento para recuperação da platina produz resultados satisfatórios, e suficientes para defini-lo como a rota a ser seguida para reciclagem da platina e analisada sob o enfoque da avaliação do ciclo de vida.

Nesta perspectiva, a fase seguinte deste trabalho foi a Avaliação do Ciclo de Vida Simplificada do processo de recuperação, cujo propósito geral é exemplificar o uso da ACV e avaliar a sua funcionalidade na definição de métodos para a reciclagem da platina da PEMFC. Desta maneira, almeja-se prover informações que associadas àquelas encontradas na análise dos estudos sobre o ciclo de vida da PEMFC, possam subsidiar as estratégias do desenvolvimento tecnológico da $\mathrm{CaC}$ no Brasil, consoante com o desenvolvimento sustentável.

\section{2 - Avaliação do Ciclo de Vida Simplificada do Processo}

Conforme apresentado no capítulo 3, a ACV simplificada é uma avaliação abrangente de todo o ciclo de vida, na qual a abordagem é superficial. Os diferentes recortes no horizonte de análise podem ser efetuados arbitrariamente, desde que coerentes com o objetivo do estudo. Exemplos de várias técnicas de simplificação de ACV podem ser encontradas em HUNT et. al (1998)

Tendo em vista, a ausência de um banco de dados, no Brasil, que descreva o inventário do ciclo de vida (ICV) de commodities ambientais básicas tais como, energia e matérias-primas elementares e, principalmente, as dificuldades de coleta e fornecimento de técnicas gerais aplicáveis para a recuperação da platina do MEA da PEMFC, optou-se por realizar a ACV simplificada. 
Desta forma, a sugestão dada em REBITZER et. al, (2004) para a simplificação da ACV foi considerada. Sendo assim, procurou-se conhecer o ciclo de vida da platina, a partir de informações encontradas na literatura especializada ${ }^{4}$. Buscou-se mapear os fluxos, processos e aspectos ambientais relevantes, na medida em que era possivel o acesso e, tratamento dos dados obtidos.

Posteriormente, foi elaborado um diagrama geral do ciclo de vida da platina e identificada a sua importância no contexto mundial e em diversos setores produtivos, principalmente no âmbito da tecnologia PEMFC. Na seqüência, a atenção do estudo foi direcionada para a etapa de gerenciamento pós-uso do MEA, especificamente na fase de recuperação e reciclagem do eletrocatalisador. Os procedimentos acima mencionados foram realizados para identificar as questões relevantes a serem consideradas na análise do processo.

Para a etapa de pré-avaliação da ACV em estudo, foi relevado o fato do ciclo de vida de um material também se constituir em uma coleção de processos, compreendidos por diversas funções, entre elas a produção de insumos e equipamentos necessários além, de consumos de recursos naturais diferenciados e dos impactos ambientais decorrentes e circunscritos a estas atividades.

Neste sentido, uma ACV completa da recuperação dos eletrocatalisadores do MEA da PEMFC constitui-se de um processo, contextualizado por diversos sistemas de produção, que por sua vez ocorrem em lugares diferentes e em indústrias pertencentes a distintas corporações. Ou seja, esta avaliação detalhada implica em uma análise seqüencial e acumulativa dos ciclos de vida abrangidos no processo (XIAO et. al, 2001).

Por esta razão, a simplificação desta ACV considerou principalmente o contexto acadêmico e as limitações da investigação científica do estudo (acessibilidade aos dados pertinentes, tratamento e recursos disponiveis). Neste sentido, a fase posterior seguiu com a abordagem metodológica proposta pela ISO, para a definição do objetivo e escopo, análise do inventário e impactos ambientais e interpretação.

${ }^{4}$ Artigos, livros, relatórios especificos, apresentações/publicações de companhias e patentes. 


\subsection{1 - Objetivo e Escopo}

O objetivo da ACV é avaliar o processo recuperação de platina desenvolvido no IPEN, paralelamente a verificação da eficácia/eficiência e o potencial de propiciar a reciclagem primária, sob o ponto de vista ambiental. $O$ nivel de sofisticação compreende uma análise simplificada, sendo o foco do estudo concentrado na etapa pós-uso dos catalisadores de platina utilizados no MEA e aos aspectos ambientais relevantes.

A função primordial estabelecida para o sistema é o de recuperar a platina dos catalisadores do MEA da PEMFC. Por não se tratar de um estudo comparativo, não foi definido a unidade funcional, nem tampouco verificado a equivalência entre processos de mesma função (pelas razões já mencionadas no item 5.1). Desta forma, somente o fluxo de referência foi estabelecido para subsidiar as informações sobre entradas e saídas do processo.

Quanto à qualidade dos dados apresentados, suas caracteristicas gerais compreendem as referências primárias obtidas em escala laboratorial e as secundárias oriundas de estudos da ACV da tecnologia PEFC. A checagem de confiabilidade priorizou o balanço de massa dos materiais elementares e suas respectivas análises de verificação (apresentadas adiante). No que tange as cortes no horizonte da análise, estes são representados em sintese pelas as fronteiras descritas a seguir:

* Fronteiras em relação ao sistema natural: inicia-se na fase na obtenção de MEA's descartados e termina no produto gerado no processo de recuperação.

* Fronteiras em relação a outros sistemas: não serão contempladas a produção de insumos, obtenção de matéria prima, os co-produtos produzidos durante $o$ processo de recuperação e tampouco os procedimentos utilizados para averiguar o material obtido. 
* Fronteiras geográficas: o processo considerado foi realizado no laboratório de componentes, do Centro de Ciência e Tecnologia de Materiais, no Instituto de Pesquisas Energéticas e Nucleares, São Paulo, Brasil.

* Fronteira temporal: o momento para o qual os dados levantados terão validade limitam-se especificamente a este estudo, sendo portanto alocado a situação atual do processo.

* Fronteiras de bens de capital: não serão incluídas as infra-estruturas necessárias para a realização do processo.

Definidos os limites e abrangência do estudo, necessários a etapa subseqüente, realizou-se as atividades envolvidas na coleta e procedimentos de cálculo dos dados do inventário.

\section{$\underline{5.2 .2-\text { Inventário }}$}

Para a elaboração do inventário foi imprescindivel definir o método de produção do MEA antes de efetuar o processo de recuperação e os procedimentos para verificação do produto obtido. Assim, a sua definição considerou o fato do IPEN estar trabalhando no desenvolvimento de várias técnicas de manufatura do MEA e de eletrocatalisadores para célula PEMFC. Dos MEA's selecionados para a realização do processo, somente em três unidades reconhecia-se o método utilizado para produzi-lo, enquanto que para os demais não era possível afirmar com precisão.

Desta forma, adotou-se que todos os MEA's foram fabricados pela mesma técnica, identificada por aquela desenvolvida por BALDO (2003). As informações da etapa de manufatura dos eletrodos de difusão gasosa foram utilizadas para calcular a massa de entrada de materiais do MEA no sistema de recuperação.

Posteriormente, efetuou-se a coleta de dados do processo. Neste sentido os MEA's com camada difusora Carbon Cloth foram numerados de 1 a 12 . Realizou-se então, o método experimental descrito no item 5.1 para cada unidade. Porém, com o intuito de mensurar a taxa de recuperação, mais uma atividade foi agregada ao procedimento, na qual se caracterizou pela pesagem dos MEA's 
completos antes do experimento e, após, dos componentes, na medida em que estes eram removidos do conjunto eletrodo membrana.

Para fins de verificação, também foram coletadas e pesadas amostras de membrana Nafion $(\mathbb{B}$ e tecido Carbon Cloth nas mesmas dimensões dos MEA's em estudo. Seqüencialmente, os solutos obtidos de cada MEA foram compostos de três em três, novamente pesados, acondicionados em frascos plásticos, identificados e conduzidos para a análise. Também foram encaminhadas amostras da platina comercial ETEK 20 e da tinta catalítica fornecidas pelo grupo técnico do Programa de CaC - PROCEL/IPEN. Outros procedimentos também foram efetuados para elaborar o inventário, os quais se constituem em:

* Software de ACV: contém um banco de dados inventariados para uma larga escala de materiais e processos. Atualmente, encontram-se no mercado diversos softwares amplamente utilizados pela comunidade européia, Japão, Estados Unidos e outros paises no exterior. Estes programas podem ser encontrados na Internet nas suas versões demo. A título de experiência selecionou-se o Sima Pro 7 Demo (Figura 5.3).

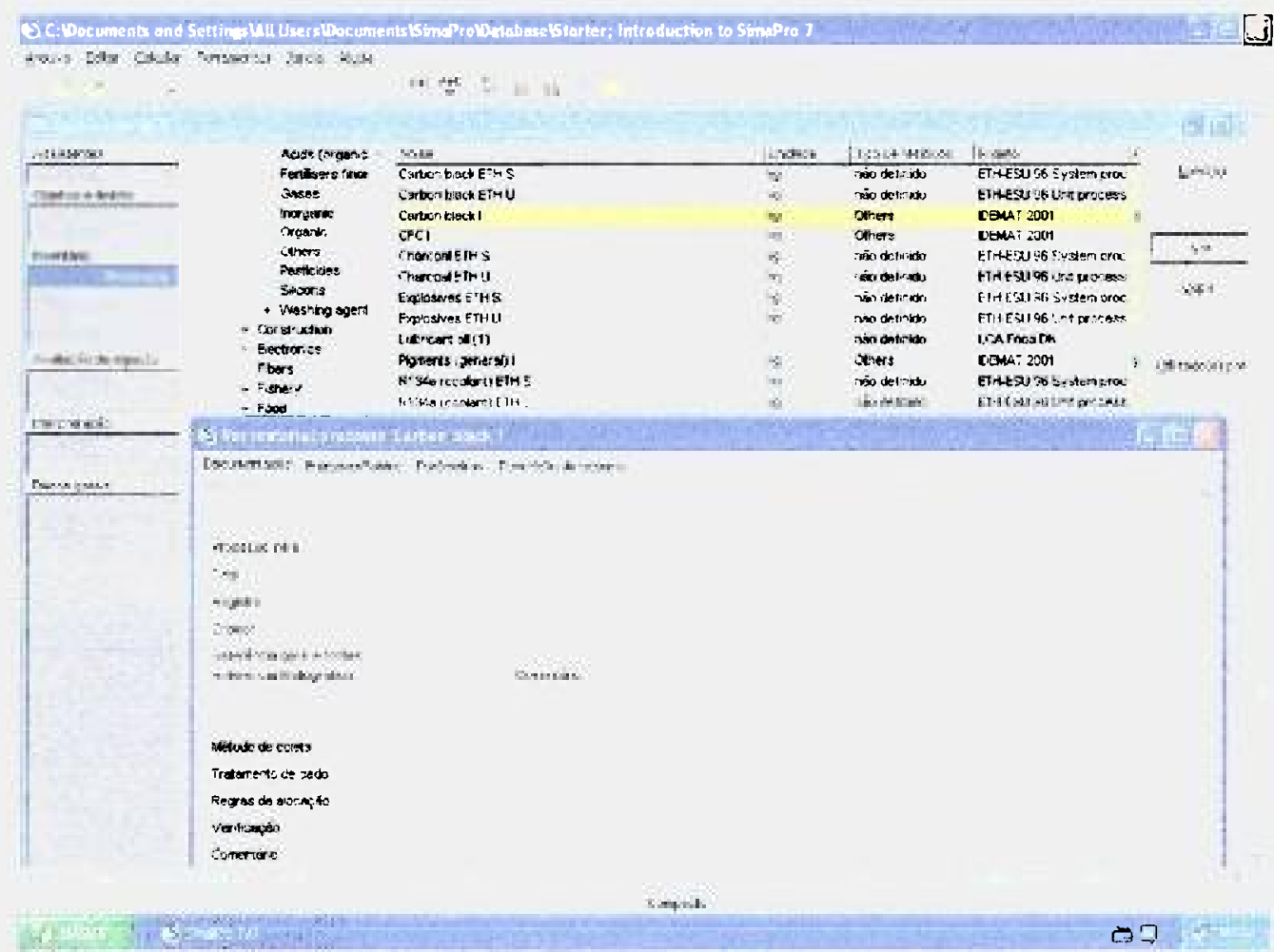

FIGURA 5.3 - Software de ACV - Sima Pro Demo. 
* Comunicação pessoal: comunicação com especialistas da área de desenvolvimento de células a combustível no IPEN, do campo de atuação em proteção ambiental da Agência Ambiental de São Paulo - CETESB, e profissionais de diferentes organizações que trabalham com a ACV.

* Elaboração de uma ficha de coleta de dados para análise do inventário com informações sobre entradas de material e energia, consumo de água, saida de material, emissões atmosféricas, emissões para a água e solo, além de outras liberações.(Figura 5.4)

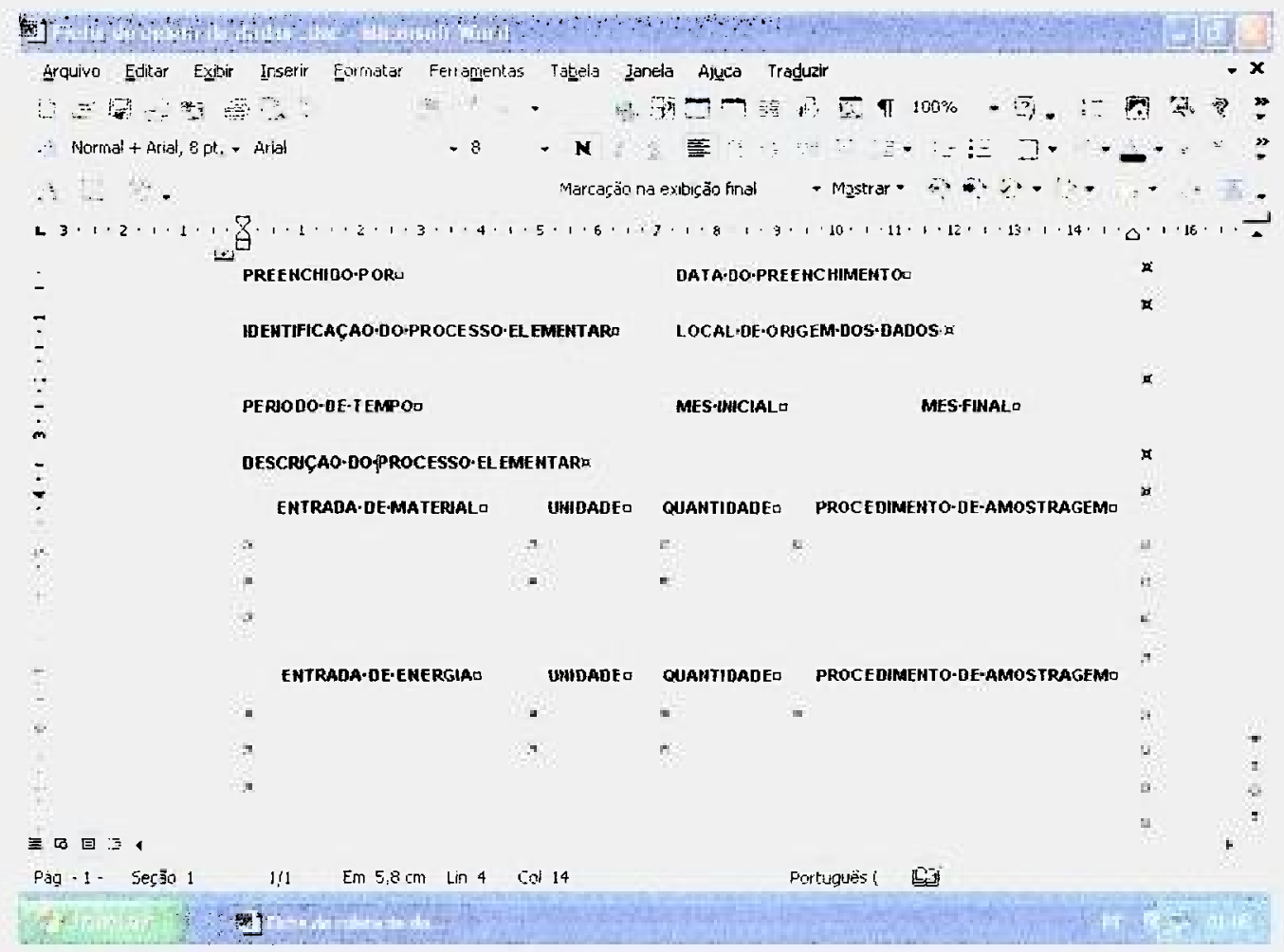

FIGURA 5.4 - Ficha de coleta de dados.

Em relação aos outros procedimentos necessários para o cálculo das saidas de materiais do MEA, a verificação do produto obtido e a viabilidade para a reciclagem primária foram determinadas à realização das análises apresentadas a seguir. 


\subsubsection{1- Análise Termogravimétrica - ATG}

Termogravimetria (TG) é a técnica na qual a mudança da massa de uma substância é medida em função da temperatura e do tempo, enquanto esta é submetida a uma programação controlada. O termo abreviado pela sigla TGA é comumente empregado, no lugar de TG por ser seu precedente histórico e para minimizar a confusão verbal com $\mathrm{Tg}$, a abreviação da temperatura de transição vitrea.

A análise é realizada em uma atmosfera definida, geralmente em condições inertes (nitrogênio) ou em um ambiente oxidativo (ar ou possivelmente oxigênio). A massa é medida em uma balança eletrônica altamente sensivel e os efeitos de interferência da flutuação e fluxo de gás são compensados por uma correção de curva branca. Esta técnica fornece informações sobre o conteúdo dos componentes voláteis como solventes ou água, de cinzas e espessantes, bem como o comportamento de decomposição térmica de elementos orgânicos, inorgânicos e biológicos ${ }^{5}$.

As análises termogravimétricas das amostras: tinta catalítica (A), as oriundas do processo de recuperação da platina (B) e da platina comercial (C) foram obtidas em um equipamento marca Mettler Toledo, modelo TGAVSDTA 851e. O material de referência utilizado para análise foi alumina, velocidade do equipamento de $10^{\circ} \mathrm{C} / \mathrm{min}$, temperatura de até $800^{\circ} \mathrm{C}$ e fluxo de oxigênio.

\subsubsection{2- Espectrometria de Fluorescência de Raios $X$ - FRX}

A FRX pode ser classificada como uma técnica de emissão atômica, fundamentada no efeito fotoelétrico. Quando um átomo é submetido a um processo de irradiação utilizando-se uma fonte de raios $X$ (tubo de raios $X$, indução por partícula, radioisótopos naturais, luz síncrotron), um elétron pode ser ejetado das camadas eletrônicas mais internas (efeito fotoelétrico). Para

\footnotetext{
${ }^{3}$ Wendhausen, $\mathrm{P}$ : Análise Termogravimétrica/Laboratório de Análises Termofísicas. Disponível em http://www materiais.ufsc.br/ atermicas/tg.htm. Acessado em 11/12/2005.
} 
estabilização desta forma excitada, elétrons das camadas eletrônicas mais externos caem rapidamente para as vacâncias geradas, liberando a diferença de energia (DE) existente entre os dois niveis de energia envolvidos.

Como este processo envolve niveis de energia que são característicos de cada elemento, a radiação emitida para cada transição é também característica. Desta maneira, a energia da radiação emitida pode ser diretamente utilizada na identificação da espécie em questão. Por outro lado, como a intensidade da radiação emitida é diretamente proporcional à concentração da espécie, a técnica também fornece informações que podem ser utilizadas para fins quantitativos.

Em situações nas quais pretende-se analisar uma amostra totalmente desconhecida, a técnica de FRX também mostra-se mais vantajosa, principalmente em função de permitir uma rápida avaliação qualitativa dos constituintes da matriz. (NAGATA et.al, 2001).

As composições quimicas das amostras A, B, C foram obtidas em um espectrômetro marca Shimadzu, modelo EDX RF 900HS. Na análise quantitativa da dispersão utilizou-se o método de Curva de Calibração (regressão linear), enquanto que nas demais análises (semiquantitativa), pelo método de Parâmetros Fundamentais (ensaio direto, não destrutivo). As amostras foram acondicionadas em porta amostra de teflon e polipropileno sob atmosfera a vácuo.

\subsubsection{3- Difração de Raios X - DRX}

A difração de raios $X$ representa o fenômeno de interação entre o feixe de raio $X$ incidente $e$ os elétrons dos átomos componentes de um material, relacionado ao espalhamento coerente. A técnica consiste na incidência da radiação em uma amostra e na detecção dos fótons difratados, que constituem o feixe difratado. Em um material onde os átomos estejam arranjados periodicamente no espaço, característica das estruturas cristalinas, o fenômeno da difração de raios-X ocorre nas direções de espalhamento que satisfazem a Lei de Bragg, conforme a equação

$$
\mathrm{n} \lambda=2 \mathrm{~d} \operatorname{seno} \theta
$$


onde $n=$ número interior de comprimento de onda; $\lambda=$ comprimento da radiação incidente; distância interplanar entre dois planos adjacentes e $\theta=$ ângulo de incidência da radiação.

No método do pó a identificação das substâncias cristalinas é obtida através da comparação do difratograma com padrões difratométricos de fases individuais disponibilizados pelo ICDD - International Center for Diffraction Data, antigo JCPDS-Joint Committee of Powder Diffraction Standards, sendo possivel também calcular os parâmetros de cela unitária, avaliar o grau de cristalinidade, bem como quantificar fases presentes. A quantificação de fases a partir da difração de raios- $X$ se apóia nas intensidades dos picos do difratograma, as quais, além de guardarem uma relação característica da estrutura cristalina de cada fase componente, refletem a proporção das fases na amostra (SILVA et. al, 2005).

Os difratograma das amostras A, B e C foram resultantes da análise realizada no difratômeto marca $R i g a k u$, modelo Multiflex, utilizando uma radiação CuKa, na faixa angular $2 \theta=20^{\circ}$ a $80^{\circ}$ e passo de varredura de $0,02^{\circ}$. Para determinar o tamanho médio das partículas (d) utilizou-se o pico referente ao plano da estrutura cúbica de face centrada da Pt em torno de $2,=40^{\circ} \mathrm{e}$ empregou-se a equação de Scherrer ${ }^{6}$.

$$
d=k \lambda / \beta \cos \theta
$$

onde: d é o diâmetro médio das partículas; $K$ a constante de proporcionalidade que depende da forma das partículas, assumida como esférica $(0,9) ; \lambda$ é o comprimento de onda da radiação de $\mathrm{Cu}\left(1,5406 \mathrm{~A}^{\circ}\right)$ e $\beta$ a largura a meia altura do pico (rad).

\subsubsection{4- Análise por Ativação Neutrônica}

A ativação neutrônica é uma técnica analítica usada para determinação da composição química elementar por meio da indução de radioatividade artificial em uma amostra, que é obtida mediante a irradiação com nêutrons e posterior 
medida da radioatividade (detector de Ge hiperpuro acoplado a espectrômetro de raios gama). Esta técnica é aplicada aos mais diversos campos de pesquisa e tecnologia, por exemplo, biologia, geoquímica, física do estado sólido, medicina, arqueologia, entre outros.

As principais caracteristicas que tornam esta técnica uma poderosa ferramenta analítica são: é aplicável a todo tipo de matriz, grande número de elementos analisáveis, capacidade de análise multielementar, independência da natureza química ou física do material, elevadas sensibilidade, seletividade, precisão e exatidão. Vale ressaltar que a técnica pode ser destrutiva ou não, isto é, não é necessário que haja tratamento químico preliminar da amostra.

As análises por ativação neutrônica das amostras A, B e C foram realizadas com irradiações ${ }^{7}$ de 30 segundos sob o fluxo de nêutrons térmicos de $10^{12} \mathrm{n} \mathrm{cm}^{-1} \mathrm{~s}^{-1}$ e de 16 horas sob fluxo de $3,6 \times 10^{12} \mathrm{n} \mathrm{cm}^{-2} \mathrm{~s}^{-1}$. Os radioisótopos utilizados foram : ${ }^{82} \mathrm{Br},{ }^{60} \mathrm{Co},{ }^{51} \mathrm{Cr},{ }^{59} \mathrm{Fe},{ }^{140} \mathrm{La},{ }^{24} \mathrm{Na},{ }^{197} \mathrm{Pt},{ }^{905} \mathrm{RU},{ }^{46} \mathrm{Sc} \mathrm{e}{ }^{65} \mathrm{Zn}$. As concentrações foram calculadas pelo método comparativo.

\subsubsection{5 - Análise de Voltametria Cíclica}

O termo voltametria engloba um grupo de métodos eletroanalíticos nos quais a informação sobre o analito deriva das medidas de corrente em função do potencial aplicado, sob condições onde o eletrodo de trabalho (ou indicador) encontra-se polarizado. A forma mais utilizada é a varredura linear de potencial, utilizada desde os primórdios da polarografia. A faixa de potencial é "varrida" em uma única direção, iniciando no potencial inicial $(t=0)$ e terminando no potencial final $(t=t f)$.

Já na voltametria ciclica, a direção do potencial é invertida ao final da primeira varredura. Então, geralmente a varredura tem a forma de um triângulo isósceles. Este processo traz a vantagem de que o produto da reação redox que ocorreu na primeira etapa de varredura (na ida), pode ser avaliado novamente na varredura reversa (na volta). A voltametria cíclica é uma ferramenta muito

Reator nuclear de pesquisa modelo IEA -RI - IPEN. 
favorável para elucidar as propriedades superficiais dos materiais e determinar a área eletroquimicamente ativa (PEREZ et. al, 1998)

A caracterização eletroquímica das amostras A, B e C foi realizada por meio de voltametrias cíclicas (VC's). Utilizou-se um eletrodo de camada fina porosa (eletrodo de trabalho), um eletrodo de referência de hidrogênio e um contra eletrodo platinizado, sendo os VC's obtidos em uma solução aquosa de $\mathrm{H}_{2} \mathrm{SO}_{4} 0,5 \mathrm{~mol} \mathrm{~L}{ }^{-1} \mathrm{e}$, na velocidade de varredura de $10 \mathrm{mV} / \mathrm{s}$. O equipamento usado foi um potenciostato da marca Microquímica, modelo MQGPG01, conectado a um microcomputador utilizando software Microquímica.

\subsection{3 - Avaliacão de Impactos do Ciclo de Vida}

Para selecionar as classes das questões ambientais relevantes, as quais os resultados do ICV podem ser associados, tornou-se necessário identificar previamente os aspectos e os impactos ambientais do processo de recuperação dos eletrocatalisadores, bem como a sua importância no escopo delimitado para o estudo.

Segundo a norma ISO 14001(1996), defini-se aspecto ambiental como elementos das atividades das organizações, produtos e serviços que podem interagir com o meio ambiente, enquanto impacto ambiental caracteriza-se por qualquer mudança no meio ambiente, adversa ou benéfica, resultante, integralmente ou parcialmente, das atividades das organizações, produtos ou serviços.

Freqüentemente, os aspectos ambientais são visualizados como as entradas do sistema produtivo e, os impactos como saídas. Contudo, é mais concludente visualizar os impactos como os resultados das saídas. Por exemplo, o descarte de efluentes (saida); pode resultar em uma crescente concentração de metais pesados no meio receptor (resposta). Um exemplo de aspectos e impactos associados a um processo, produto e serviço, pode ser visualizado na TAB 5.2. 
TABELA 5.2 - Exemplo de aspectos e impactos

\begin{tabular}{c|c|c}
\hline ELEMENTO & ASPECTO & IMPACTO \\
\hline $\begin{array}{c}\text { PROCESSO: MANUFATURA DE } \\
\text { MONÓMERO ACRILONITRILA }\end{array}$ & $\begin{array}{c}\text { INJEÇÅO DE SULFATO DE AMÓNIA } \\
\text { EM POÇOS DE PROFUNDIDADE }\end{array}$ & $\begin{array}{c}\text { CONTAMINAÇÃO DEÁGUAS } \\
\text { SUBTERRÂNEAS }\end{array}$ \\
\hline $\begin{array}{c}\text { PRODUTO: SPRAY DE CABELO } \\
\text { SERVIÇO: MANUTENÇĂO DE } \\
\text { JARDINS }\end{array}$ & PROPULSOR, SOLVENTE & $\begin{array}{c}\text { DEPLEÇÃO DA CAMADA DE } \\
\text { OZÔNIO }\end{array}$ \\
\hline
\end{tabular}

Fonte: BLOCK (1999), modificado FUKUROZAKI (2006)

Neste sentido, procurou-se verificar nas entradas, fluxos e saídas do processo, levantadas no inventário, quais os elementos que poderiam interagir com o meio ambiente. Devido à natureza específica do método de recuperação, considerou-se o uso de substâncias quimicas, materiais processados, energia e recursos naturais.

A etapa subseqüente consistiu em identificar os potenciais impactos em função dos aspectos ambientais. Desta maneira, definiu-se as categorias e os possiveis indicadores de impactos. Posteriormente, a fase seguinte da caracterização buscou definir a medida quantitativa do perfil de depleção.

No entanto, verificou-se que modelos de caracterização, principalmente no que tange aos procedimentos de cálculo, demandavam uma enorme quantidade de dados especificos. Por exemplo, os métodos existentes sobre perda de biodiversidade se baseiam em informações científicas sobre a densidade das espécies e produção primária dos ecossistemas específicos do local de estudo. (cf. SUPPEN \& ABITIA, 2005). Conseqüentemente, esta atividade implicaria em tempo e outros recursos não disponíveis para o presente trabalho.

Embora, técnicas de caracterização para a categoria de aquecimento global, emissões ácidas e mudanças climáticas do Painel Intergovernamental de Mudança Climática - IPCC possam ser aplicáveis, observou-se que devido às peculiaridades do processo (ver item 5.1 deste capítulo) e seus reflexos no inventário, a contribuição relativa das entradas e saídas do sistema não seriam significativas, o que poderia acarretar em uma análise equivocada do efeito do impacto. 
Neste contexto, a estimativa da significância dos impactos contemplou somente a análise qualitativa. Para tanto, os critérios de avaliação foram selecionados com base na proposta de BLOCK (1999) e, de acordo com a sua utilização e escalas mais comumente empregadas pelas organizações (ibidem, 1999). Assim sendo, os parâmetros e respectivos conjuntos de pontuação utilizados foram:

1)- Probabilidade: identifica a probabilidade de impacto em função da sua possivel ocorrência (TAB 5.3)

TABELA 5.3 - Escala de probabilidade

\begin{tabular}{c|c|l}
\hline Pontuação & \multicolumn{1}{|c|}{ Tipo } & \multicolumn{1}{c}{ Descrição } \\
\hline $\mathbf{5}$ & Muito provável & $\begin{array}{l}\text { Alta probabilidade: (90\% ou mais) de que tal aspecto possa resultar em um impacto } \\
\text { detectável }\end{array}$ \\
\hline $\mathbf{4}$ & Provável & $\begin{array}{l}\text { Forte probabilidade: (68\% a 89\%) de que tal aspecto possa resultar em um impacto } \\
\text { detectável }\end{array}$ \\
\hline $\mathbf{3}$ & Moderado: & $\begin{array}{l}\text { Moderada probabilidade (34\% a 67\%) de que tal aspecto possa resultar em um } \\
\text { impacto detectável }\end{array}$ \\
\hline $\mathbf{2}$ & Leve & $\begin{array}{l}\text { Baixa probabilidade (11\% a 33\%) que tal aspecto possa resultar em um impacto } \\
\text { detectável }\end{array}$ \\
\hline
\end{tabular}

Fonte: BLOCK, 1999

2)-Severidade: refere-se ao grau em que as áreas de entorno (incluindo o ar, água, terra e outros recursos naturais e humanos) são afetados pelos impactos (TAB 5.3).

TABELA 5.4 - Escala de severidade

\begin{tabular}{c|c|c}
\hline Pontuação & Tipo & Descrição \\
\hline $\mathbf{5}$ & Severo/catastrófico & Muito perigoso ou potenciaimente fatal; grandes esforços para corrigir ou recuperar \\
\hline 4 & Sério: & Perigoso mas não potencialmente fatal, dificuldade de corrigir mas recuperável \\
\hline \hline 3 & Moderado: & Algumas vezes perigoso, corrigivel \\
\hline 2 & Leve & Pequeno potencial de dano, facilmente corrigivel \\
\hline $\mathbf{1}$ & Inofensivo: & Sem potencial de dano, corrigivel \\
\hline
\end{tabular}

Fonte: BLOCK, 1999 
3)- Limites: os limites geográficos refletem as áreas físicas em que os impactos podem ocorrer (TAB.5.5).

TABELA 5.5 - Escala de limites

\begin{tabular}{c|c|l}
\hline Pontuação & Tipo & \multicolumn{1}{c}{ Descrição } \\
\hline $\mathbf{5}$ & Global & Migração dos impactos para outros países \\
\hline 4 & Regional & Migração dos impactos para regiões do pais onde eles ocorrem \\
\hline 3 & Local & Migração dos impactos para os locais de entorno \\
\hline 2 & Confinado & Migração dos impactos para áreas adjacentes ao espaço físico em que ocorrem \\
\hline 1 & Isolado & Migração dos impactos contida dentro do espaço físico onde ocorrem \\
\hline
\end{tabular}

Fonte: BLOCK, 1999, modificado por FUKUROZAKI (2006)

4)- Status regulatório: identifica se os impactos estão associados a exigências governamentais (leis, resoluções, normas) ou não (TAB 5.6)

TABELA 5.6 - Escala de status regulatório

\begin{tabular}{c|c|l}
\hline Pontuação & \multicolumn{1}{|c|}{ Tipo } & \multicolumn{1}{c}{ Descrição } \\
\hline $\mathbf{5}$ & $\begin{array}{c}\text { Regulado } \\
\text { legalmente }\end{array}$ & $\begin{array}{l}\text { Leis, resoluçōes, normas, portarias, decretos, padrões designados pela agência } \\
\text { ambiental federal, estadual ou local }\end{array}$ \\
\hline $\mathbf{4}$ & $\begin{array}{c}\text { Regulado no } \\
\text { futuro }\end{array}$ & $\begin{array}{l}\text { Não regulado mas com algumas considerações do governo ou com potencial para ser } \\
\text { regulado no futuro }\end{array}$ \\
\hline $\mathbf{3}$ & $\begin{array}{c}\text { Política da } \\
\text { organização }\end{array}$ & $\begin{array}{l}\text { Padrões industriais, código de práticas ou outras iniciativas adotadas e formalizadas } \\
\text { pelas organizações }\end{array}$ \\
\hline $\mathbf{2}$ & $\begin{array}{c}\text { Prática da } \\
\text { organização }\end{array}$ & $\begin{array}{l}\text { Padrões industriais, códigos de praticas ou outras iniciativas não formaimente } \\
\text { estabelecidas para as práticas }\end{array}$ \\
\hline $\mathbf{1}$ & Não regulado & Sem referência \\
\hline
\end{tabular}

Fonte: BLOCK (1999), modificado por FUKUROZAKI (2006)

Todos os impactos identificados refletem uma posição em um dado parâmetro, assim, o passo seguinte da avaliação consistiu em determinar a significância dos impactos pela avaliação múltipla dos critérios selecionados, como exemplifica a TAB 5.7. 
TABELA 5.7 - Exemplo da avaliação múltipla dos critérios

\begin{tabular}{c|c|c|c|c|c}
\hline Impactos & Probabilidade & Severidade & Limites & Status regulatório & Significância \\
\hline Impacto 1 & 3 & 2 & 2 & 1 & 12 \\
\hline Impacto 2 & 3 & 1 & 1 & 2 & 6 \\
\hline
\end{tabular}

Os dados obtidos no inventário e na avaliação de impactos do processo de recuperação da platina na avaliação foram sumarizados e apresentados na formas de figuras, tabelas e gráficos.

\subsection{4 - Interpretacão}

Os resultados alcançados na ACV simplificada do sistema estudado foram sumarizados, além de checados e avaliados quanto às exigências do objetivo e escopo delimitados. As informações decorrentes das atividades mencionadas nessa etapa são apresentadas, neste trabalho, no capítulo 6 e nas conclusões. 


\section{6 - AVAliaçÃo do CICLO de VIDA do PROCESSO DE RECUPERAÇÃO DOS CATALISADORES DA PEMFC}

Neste capítulo, os resultados significativos alcançados são relatados e discutidos em três partes seqüenciais. Conforme descrito na metodologia, a primeira seção, diz respeito à etapa de pré-avaliação, na qual são identificadas às questões relevantes sobre a platina. A segunda consiste nos resultados derivados dos procedimentos de coleta e análise dos dados inventariados no processo de recuperação dos catalisadores do MEA. Por fim, a última parte traz as informações oriundas da avaliação de impactos da ACV.

\section{1- Pré Avaliação da ACV : questões relevantes sobre a platina}

Conforme verificado nos capitulos anteriores (cap. 2 e 5), uma das grandes preocupações em relação ao desenvolvimento da $\mathrm{CaC}$ do tipo PEMFC, incide sob o custo da platina, no qual, tanto a disponibilidade do recurso na natureza, quanto - seu suprimento pelas atividades de extração e beneficiamento, estão intimamente relacionados.

Segundo Penã et. al (2005), as reservas minerais caracterizam-se na fração identificada e economicamente recuperável dos recursos naturais para um dado elemento ou composto, que tendem a variar com o decorrer do tempo, por um lado devido à exploração e, por outro, pelo reconhecimento de novas jazidas que permitem repô-las e inclusive aumentá-las por um determinado período.

Neste sentido, os metais que passam a formar parte dos processos ou dos produtos industriais constituem-se na parcela, na qual eventualmente é possivel reciclar e dar uma nova função (recursos secundários). Porém, parte dos metais contidos em diversos produtos se perde por estar demasiadamente diluído ou associado a outros compostos, nos quais é muito difícil separá-los.

Todavia, fatores econômicos (variações no preço do mercado), técnicos (aplicações de novas tecnologias), ambientais (maiores exigências regulatórias) e 
sociais (padrões de consumo) podem por sua vez determinar a viabilidade de exploração dos recursos e, decidir desta forma o uso e os recursos marginais.

Destarte, as informações relacionadas ao ciclo de vida do mineral podem indicar os fatores importantes a serem considerados no processo de recuperação e de outra forma, apontar as questões ambientais a serem ponderadas no que tange a exploração e o esgotamento do recurso, bem como as conseqüências no meio ambiente e na saúde humana.

Entretanto, a enorme quantidade de informações requeridas e a ausência de dados confiáveis necessários, além dos aspectos inerentes à coleta e ao tratamento, torna a tarefa de identificar estas questões um processo extremamente complexo e laborioso. Portanto, considerando as limitações do estudo, a determinação dos principais fatores consistiu em uma abordagem superficial e exploratória da ACV da platina.

Assim sendo, a construção do diagrama geral do ciclo de vida limitou-se a ilustrar a cadeia de relações com diferentes setores produtivos e as principais fases relacionadas a sua produção (FIG 6.1).

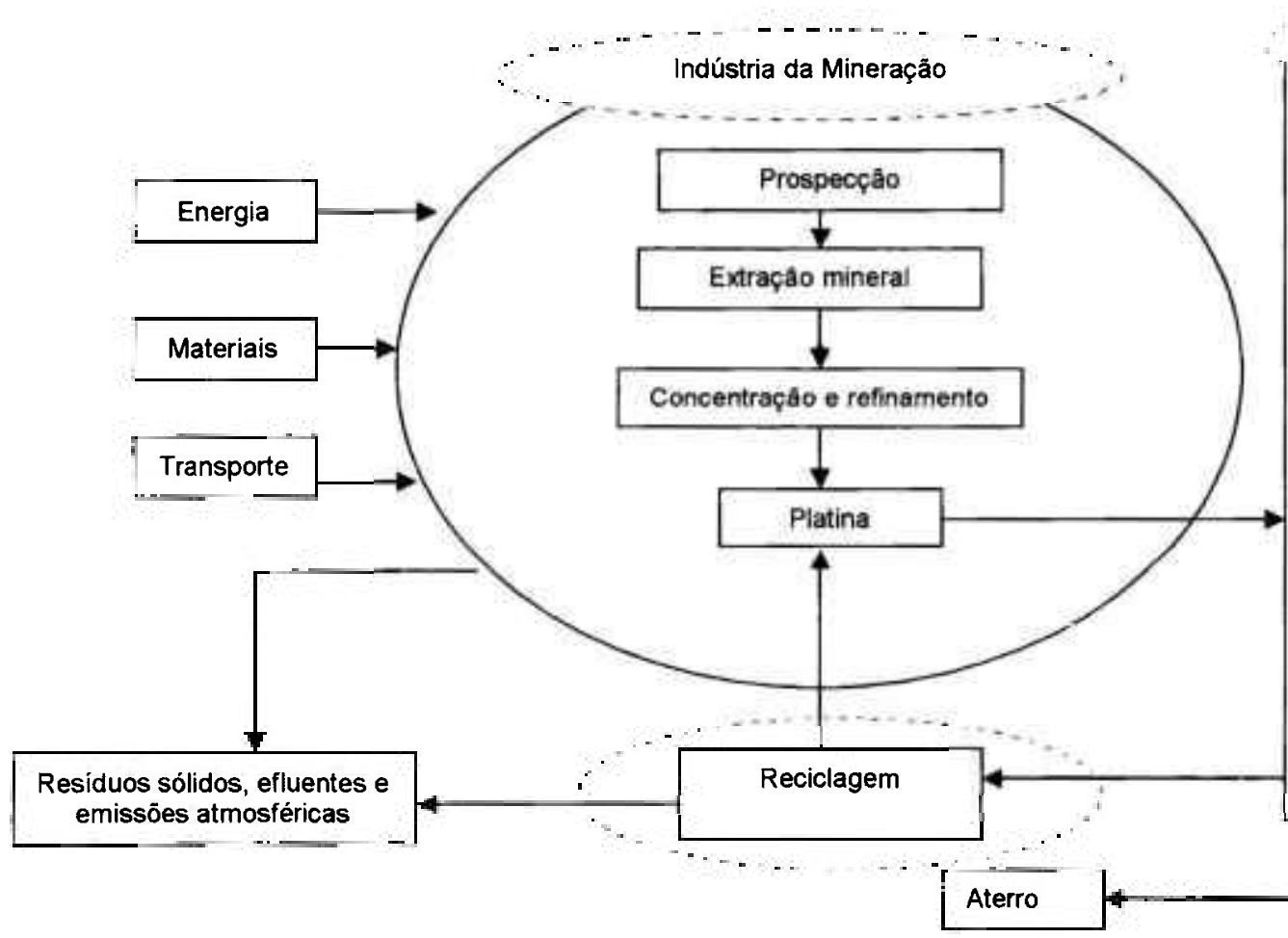

Setores de demanda

Industria automobilística
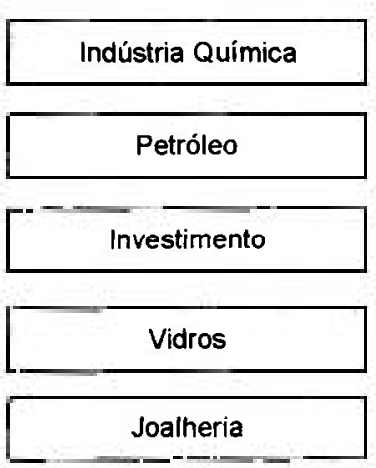

Elétrico

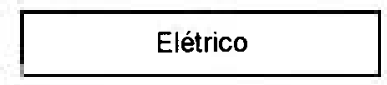

CaC e outros 
Resumidamente, o ciclo inicia-se com a prospecção mineral (identificação, mapeamento e análise das regiões economicamente viáveis), seguidas pela exploração do minério (extração das rochas), produção de platina fisicamente pura (concentração) e quimicamente pura (refinamento).

A platina depois de refinada apresenta uma pureza de mais de $99,95 \%$ e podem ser produzido em várias formas: lingote, grãos ou como um pó conhecido como "sponge". O tempo entre a mineração típica e a produção do metal puro gira em torno de 6 semanas (MATTHEY, 2006). Para cada setor de demanda, existe uma cadeia de bens e serviços especificos que atuam no processamento e fornecimento do material conforme as suas necessidades.

Neste panorama, na história da descoberta da platina', é possivel verificar que suas propriedades, na medida em que estas eram constatadas pelos exploradores e pesquisadores, induziram no decorrer do tempo o desenvolvimento de métodos de extração e refinamento, bem como propiciaram a sua aplicação em diferentes setores. Desta forma, apresenta-se a seguir uma síntese dos fatores identificados, no contexto da demanda primária e especialmente no que tange a tecnologia PEMFC.

\subsubsection{Propriedades Gerais}

Os metais do grupo da platina - MGP compreendem seis elementos químicos: platina $(\mathrm{Pt})$, paládio $(\mathrm{Pd})$, ródio $(\mathrm{Rh})$, rutênio $(\mathrm{Ru})$, ósmio $(\mathrm{Os})$ e irídio (Ir), os quais apresentam caracteristicas quimicas semelhantes e ocorrem associadamente na natureza. Igualmente como o ouro e a prata são conhecidos como metais preciosos ou nobres, bem como, por possuirem extraordinárias propriedades: são refratários, quimicamente inertes a elevadas temperaturas e a uma ampla gama de materiais e, possuem excelente atividade catalitica.

Ainda, os MGP possuem densidade e pontos de fusão bastante elevados, sendo $o$ irídio o elemento químico mais denso que ocorre na natureza $(d=22,65$ ). Ocorrem em depósitos, quase sempre relacionados a complexos máficosultramáficos, sob a forma de compostos químicos e ligas naturais, em variada e

Consulte MATTHEY, 2006. 
complexa mineralogia. A TAB. 6.1 apresenta as características da platina, principal material de interesse do estudo.

TABELA 6.1 - Propriedades da platina

\begin{tabular}{c|c}
\hline PROPRIEDADES & PLATINA \\
\hline Classe de substâncias elementares & Metal \\
\hline Origem & Natural \\
\hline Densidade $(298 \mathrm{k})$ & $21450 \mathrm{~kg} \mathrm{~m}^{-3}$ \\
\hline Rede cristalina & Cúbica de face centrada \\
\hline Ponto de fusão & $1772^{\circ} \mathrm{C}$ \\
\hline Ponto de ebulição & $3827^{\circ} \mathrm{C}$ \\
\hline Condutividade elétrica & $9,43 \times 106 \mathrm{Ohm}^{-1} \mathrm{~m}^{-1}$ \\
\hline Condutividade térmica & $71,6 \mathrm{~W} \mathrm{~m}^{-1} \mathrm{~K}^{-1}$ \\
\hline Calor de fusão & $19,7 \mathrm{~kJ} \mathrm{~mol}^{-1}$ \\
\hline Calor de vaporização & $510,5 \mathrm{~kJ} \mathrm{~mol}^{-1}$ \\
\hline Calor de atomização & $565 \mathrm{~kJ} \mathrm{~mol}^{-1}$ \\
\hline
\end{tabular}

Nos compostos químicos, os MGP estão combinados com oxigênio, enxofre, arsênico, bismuto, telürio, estanho e chumbo, entre outros. Na platina em particular, outros elementos comumente associados são: cloro, carbono e nitrogênio, exemplos de substâncias compostas e o seu estado de oxidação são apresentados na TAB. 6.2.

TABELA 6.2 - Estado de oxidação e compostos de platina

\begin{tabular}{|c|c|}
\hline ESTADO DE OXIDAÇĀO & SUBSTĀNCIAS \\
\hline$\overline{\mathbf{P t}^{0}}$ & {$\left[\mathrm{Pt}\left(\mathrm{PPh}_{3}\right)_{3}\right]_{i}\left[\mathrm{Pt}\left(\mathrm{PF}_{3}\right)_{4}\right]$} \\
\hline $\mathbf{P t}$ & $\mathrm{PtO} ; \mathrm{PtCl}_{2} ; \mathrm{PtBr}_{3} ; \mathrm{Ptl}_{2} ; \overline{\mathrm{PtCl}}_{4}^{2} ;\left[\mathrm{Pt}(\mathrm{CN})_{4}\right]^{2-} ;$ complexos \\
\hline $\mathbf{P t}^{\mathrm{N}}$ & $\mathrm{PtO}_{2} ;\left[\mathrm{Pt}(\mathrm{OH})_{6}\right]^{2-}(\mathrm{aq}) ; \mathrm{PtF}_{4} ; \mathrm{PtCl}_{4} ; \mathrm{PtCl}_{6}^{2} ;$ complexos \\
\hline $\overrightarrow{\mathrm{Pt}}$ & $\left(\mathrm{PtF}_{5}\right)_{4} ; \mathrm{PtF}_{6}^{-}$ \\
\hline $\mathrm{Pt}^{\mathrm{n}}$ & $\mathrm{PtO}_{3} ; \mathrm{PtF}_{6}$ \\
\hline
\end{tabular}

Nas ligas naturais os MGP encontram-se associados em variadas proporções, com titânio, ferro, ouros e, entre outros, ao mercúrio. Os minerais mais comuns são a sperrita, braguitta, cooperita, platina nativa, paládio nativo e osmirídio. 
Especialmente, nas células a combustivel, devido as suas propriedades químicas, a platina é o catalisador por excelência ${ }^{2}$ para os processos de oxidação e redução necessárias ao funcionamento da PEMFC (SALGADO \&GONZALEZ, 2003).

\subsubsection{Demanda e Aplicações}

Face as suas qualidades físicas e químicas, a platina em específico, é amplamente utilizada em joalherias (FIG 6.2), investimentos de reserva de valor (FIG. 6.3), em diversas indústrias, tais como: a automotiva, a química e a elétrica, especialmente na eletroeletrônica e, em dispositivos de controle ambiental (FIG 6.4).

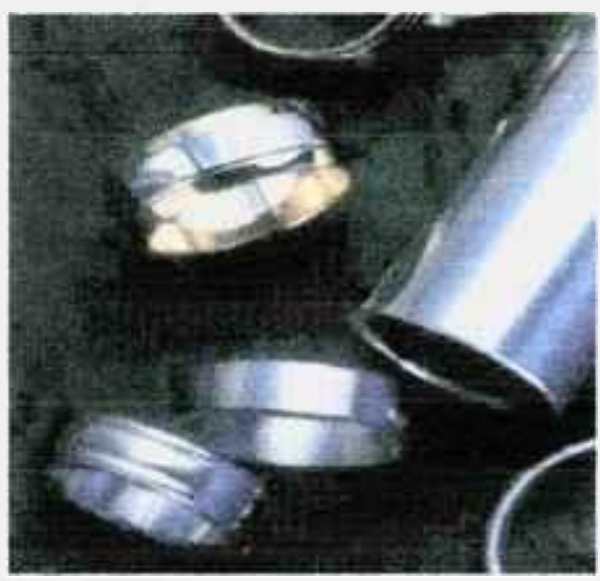

FIGURAS 6.2 - Jóias de platina

Fonte: MATTHEY, 2006

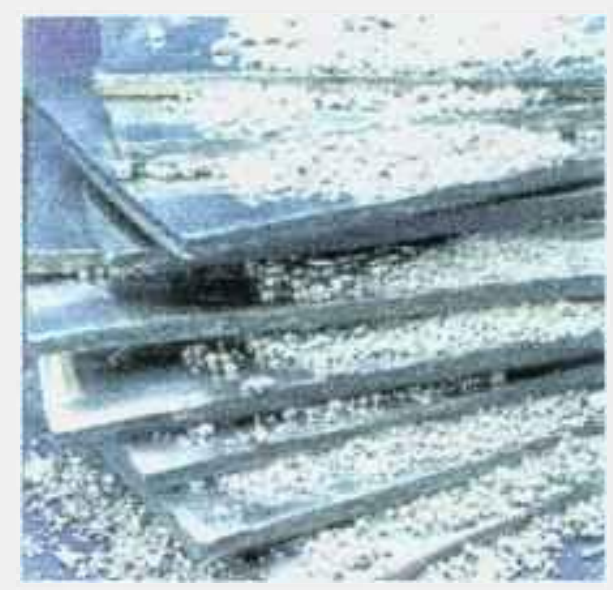

FIGURA 6.3 - Platina em barra e grãos Fonte: MATTHEY, 2006

\footnotetext{
- Alta atividade eletrocatalisadora. estabilidade e condutividade clétrica.
} 


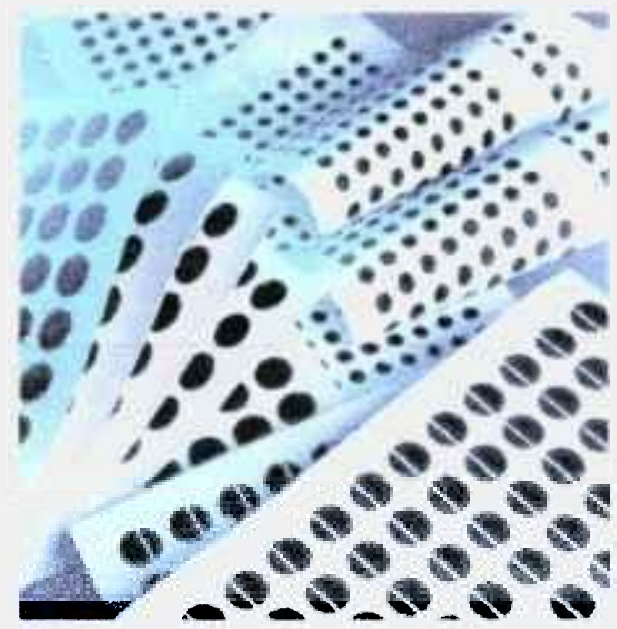

FIGURA 6.4 - Sensor de platina utilizado para detectar monóxido de carbono

Fonte: MATTHEY, 2006

Em muitos países, o consumo de platina está relacionado à sua utilização como catalisadores, principalmente em automóveis ${ }^{3}$ (autocatalisadores) e, em processos industriais, como por exemplo, da indústria petrolífera ${ }^{4}$ (FIG 6.5). Outras aplicações deste metal são: os condutores elétricos (cabos de fibraótica), dispositivos de extrusão, próteses dentárias, medicamentos, bem como o uso na produção de vidros e no setor químico, na manufatura de silicone e fertilizantes.

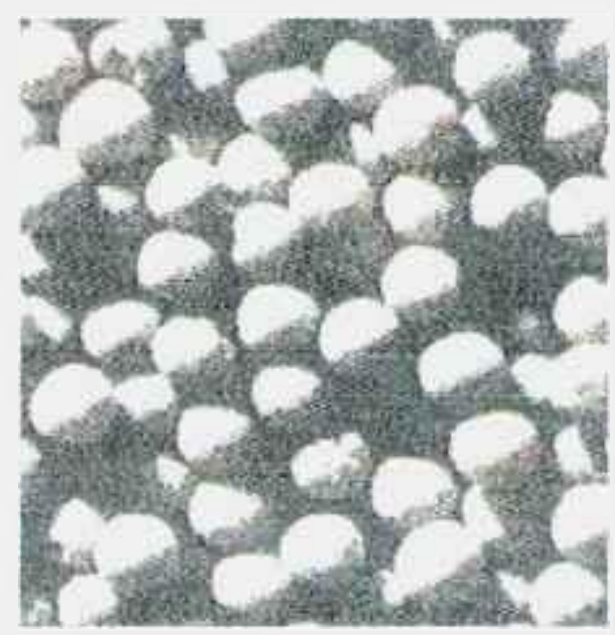

FIGURA 6.5 - Platina ancorada em substrato de alumina, utilizada como catalisador em processos da indústria petrolifera

Fonte: MATTHEY, 2006

\footnotetext{
Purificação dos gases do escapamento por oxidaçào catalítica.

Preparação da gasolina para aumentar a octanagem por isomerização.
} 
Por fim, soma-se ainda uma demanda relativa à especulação (ativo financeiro), a fabricação de unidades de disco rígido para computadores (FIG 6.6) e, recentemente, as tecnologias de ponta, como no caso da célula a combustivel. Especificamente, na PEMFC, a platina é empregada na produção dos eletrodos de difusão gasosa, como eletrocatalisadores (cf. cap.2).

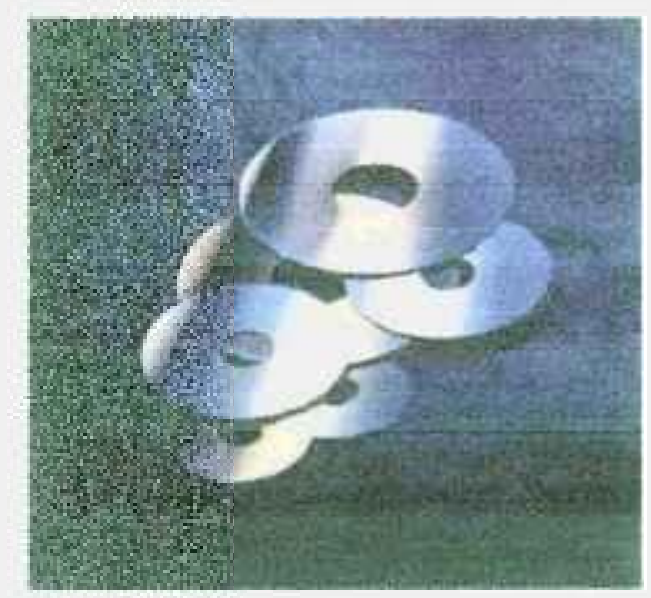

FIGURA 6.6 - Disco rígido com camada magnética de platina Fonte: MATTHEY, 2006

De acordo com Department for Transport - DFT (2004), a projeção de demanda para a platina depende de diferentes parâmetros, tais como: reserva estimada, fatores de oferta e procura, além da taxa de reciclagem. A TAB 6.3 apresenta a demanda de platina nos principais setores nos últimos dois anos.

TABELA 6.3 - Demanda de platina por setor em quilogramas $(\mathrm{kg})$

\begin{tabular}{c|c|c}
\hline DEMANDA & $\mathbf{2 0 0 \mathbf { 4 } ^ { * }}$ & $\mathbf{2 0 0 5 ^ { * }}$ \\
\hline Autocatalisadores (total) & 106800 & 115800 \\
\hline Autocatalisadores (recuperados) & 21150 & 24000 \\
\hline Industria química & 9750 & 9600 \\
\hline Industria elétrica & 9000 & 106650 \\
\hline Vidros & 8700 & 9450 \\
\hline Investimentos (baixos) & 750 & 600 \\
\hline Investimentos (altos) & 450 & 150 \\
\hline Joalherias & 64800 & 60600 \\
\hline Petróleo & 4500 & 4800 \\
\hline Outros & 14100 & 13950 \\
\hline Tolal & 197700 & 201300 \\
\hline
\end{tabular}


Comumente, a exploração de novos recursos para fins de suprimento tem sido realizada em função das expectativas e crescimento do consumo. Conforme MATTHEY (2005), um significativo aumento é esperado no setor automotivo, tendo em vista que as restrições legais dos padrões de emissões veiculares têm promovido o uso significativo da platina como catalisadores dos automóveis e, conduzido a um avanço no desenvolvimento dos veículos movidos à tecnologia $\mathrm{CaC}$ (cf. cap. 2).

\subsubsection{Suprimento e Preco}

As reservas mundiais estão extremamente concentradas na África do Sul (em torno de $77 \%$ ), com segundo destaque para a Rússia (13\%). Estes dois países são responsáveis por cerca de $90 \%$ do suprimento de platina no mundo, enquanto a América do Norte e outras regiões respondem pelo restante do fornecimento deste metal nobre (TAB 6.4).

Segundo o Departamento Nacional de Produção Mineral (DPNM,2002), não há não registros de produção nem de reservas no Brasil, embora haja indícios favoráveis, principalmente condições geológicas tecnicamente propícias e, atividades prospecção de MGP no país.

TABELA 6.4 - Suprimento de platina por região em quilogramas $(\mathrm{kg})$

\begin{tabular}{|c|c|c|}
\hline SUPRIMENTO & 2004 & 2006 \\
\hline África do Sul & 149100 & 153600 \\
\hline Rússia & 25500 & 25800 \\
\hline América do Norte & 10740 & 10200 \\
\hline Outros & 7650 & 8100 \\
\hline Total & 193800 & 197700 \\
\hline
\end{tabular}

Em relação ao suprimento, a tendência histórica entre a oferta e a procura, indica que este geralmente atende a demanda. No entanto, de acordo MATTHEY (2005), em 2004 e 2005, o mercado de platina apresentou um moderado déficit, resultando no aumento relativamente expressivo do preço, de $\$ 861 / 28,3 \mathrm{~g} \mathrm{em}$ janeiro de 2004 para $\$ 980 / 28,3 \mathrm{~g}$ em dezembro de 2005 (FIG 6.7). 


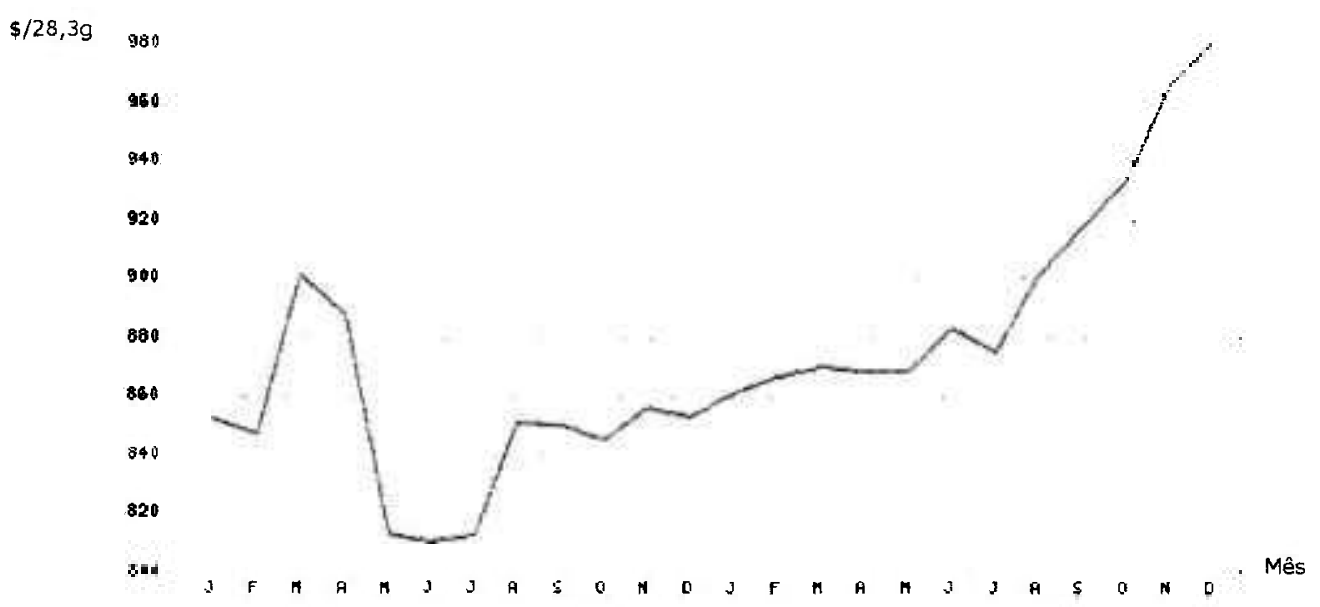

FIGURA 6.7 - Preço da platina no período de janeiro de 2004 a dezembro de 2005 Fonte: MATTHEY, 2006

Por conseguinte, baseando-se nos dados do relatório do National Renewable Energy Laboratory (2005), para o setor produtivo da PEMFC este acréscimo no valor da platina, no mesmo período, provocou um aumento significativo do custo da produção dos eletrodos de difusão gasosa - EDG (315\%), no quais a platina é o principal componente (TAB 6.5).

TABELA 6.5 - Custo da fabricação do EDG da PEMFC e porcentagem do aumento em entre os anos 2004 e 2005

\begin{tabular}{c|c|c|c|c}
\hline COMPONENTE & $\begin{array}{c}2004 \\
\text { CUSTO }\left(\mathbf{s} / \mathbf{m}^{2}\right)\end{array}$ & $\begin{array}{c}2005 \\
\text { CUSTO }\left(\mathbf{s} / \mathbf{m}^{2}\right)\end{array}$ & $\begin{array}{c}\% \\
\text { aumento }\end{array}$ & OBSERVAÇÕES \\
\hline ELETRODOS (EDG) & 67,19 & 279,02 & 315 & $\begin{array}{c}\text { Carga da platina } 0,75 \\
\mathrm{mg} / \mathrm{cm}^{2}\end{array}$ \\
\hline
\end{tabular}

Fonte: NRE (2005), modificado por FUKUROZAKI (2006)

Desta forma, mesmo com um controle de perdas do material ou redução das cargas do catalisador, por melhorias no processo de fabricação, as despesas não seriam arrefecidas, devido à ampliação da demanda deste metal nobre por outros setores produtivos e déficit do suprimento. 
Ademais, segundo o relatório do DFT (2004), o mercado da platina é muito inconstante, resultando em padrões de preços cíclicos para cada um dos principais dos MGP (platina, paládio e ródio) e, embora as atuais pressões da demanda possam ser aliviadas pela crescente produção das minas da África do Sul e exportações da Rússia, a longo prazo o suprimento é muito incerto.

Neste cenário, GROT (2003) aponta que se o potencial da tecnologia PEMFC para aplicações móveis vier a se realizar ${ }^{5}$, a disponibilidade dos MGP pode resultar, no decorrer do tempo, em uma séria limitação para o futuro da $\mathrm{CaC}$, primeiro pelo aumento do preço e em seguida pelo esgotamento do recurso. Por conseguinte, a reciclagem da platina torna-se imprescindivel para a sustentabilidade econômica da PEMFC, assim como para a manutenção do equilíbrio ecológico visto que os principais impactos identificados na literatura estão relacionados à sua demanda primária.

\subsubsection{Impactos Ambientais e Restricões Leqais}

Os impactos ambientais significativos estão associados à extração mineral e ao refinamento da platina. Em termos gerais, os efeitos nocivos ao meio ambiente ocorrem principalmente pelo uso e degradação do solo e pela poluição do ar, por emissões não controladas de dióxido de enxofre $\left(\mathrm{SO}_{2}\right)$, amônia, cloro e, entre outros, ácido clorídrico. As emissões de $\mathrm{SO}_{2}$ e $\mathrm{NH}_{4}$ são responsáveis por precipitações ácidas, cujo efeito pode atingir a escala regional (DFT, 2004).

De acordo com OKOINSTITUTE (1997), o estudo sobre a "pegada ambiental $^{6 "}$ de autocatalisadores, revelou também que nas referidas etapas produtivas cada grama de platina requer $23,76 \mathrm{kWh}$ de eletricidade e 10,45 MJ de gás natural. Estes valores são equivalentes a $6,4 \mathrm{~kg}$ de carbono por grama de platina ou $180 \mathrm{~kg}$ por onça de $\mathrm{Pt}$, considerando fatores de emissão comuns à África do Sul (cf. DFT, 2004). Essas emissões de carbono contribuem para impactos de ordem global, tais como o aquecimento e outras mudanças climáticas.

\footnotetext{
${ }^{5} \mathrm{O}$ sucesso da adoção de CaC nas aplicações móveis (transporte) em longo prazo pode criar um mercado na ordem de 10 milhões de veículos (CARLSON, 2003).

${ }^{6}$ Também conhecida como pegada ecológica; fornece uma medida do impacto das atividades antrópicas no meio ambiente.
} 
Outros impactos estão relacionados ao destino ambiental da platina pósuso e à exposição ocupacional. Segundo Hazardous Substances Data Bank HSDB (2006), este metal, devido ao seu valor, recebe muitos cuidados durante os processos de mineração para evitar perdas significativas, além de uma relativa atenção no uso e descarte de objetos.

Apesar disso, o uso de compostos de platina ${ }^{7}$ como no caso dos catalisadores de automóveis resultam em liberações difusas no ambiente, por exemplo: sais de platina particulados no ar, precipitados na forma seca ou úmida no solo, dispersos na água e transformados por bactérias em complexos metilplatinicos.

Referências de estudos sobre as concentrações de platina encontradas em diversos compartimentos ambientais, na fauna, na flora e outros locais, bem como possiveis implicações, são apresentadas na TAB 6.6.

TABELA 6.6 - Referências de estudo sobre a concentração de platina em diferentes compartimentos ambientais, na fauna na fauna e outros locais

\begin{tabular}{c|c}
\hline LOCAL & REFERENCIAS \\
\hline Água Potável & ENVIRONMENTAL HEALTH CRITERIA - WHO (1991) \\
\hline $\begin{array}{c}\text { Água Superficial } \\
\text { Efluentes }\end{array}$ & BAREFOOT (1997) \\
\hline Solos & WASCHKA \& NACHTWEY (1997) \\
\hline Sedimentos & BAREFOOT (1997) \\
\hline $\operatorname{Ar}$ (Zona Urbana) & WHO (1991); ZEIRINI et. al. (2001) \\
\hline Ar (Zona Rural) & WHO (1991) \\
\hline Flora & BAREFOOT (1997); WHO (1991) \\
\hline Fauna & RENNER \& SCHMUCKLER (1991) \\
\hline Outros (rodovia, túnel) & BAREFOOT (1997); WHO (1991); CZERCZAK \& GROMIEC (2001) \\
\hline
\end{tabular}

No que tange a saúde humana, as exposições ocupacionais ocorrem durante a mineração e nos procedimentos de refinaria. Todavia, a mais comum e atual exposição ocupacional ocorre pela inalação de compostos de platina solủveis no beneficiamento do mineral e na manufatura de catalisadores. Ademais dados de monitoramento indicam que a população em geral pode ser exposta, via inalação do ar , principalmente em estradas (HSDB, 2006).

\footnotetext{
Platina na forma de ions e compostos orgânicos e inorgânicos.
} 
Conforme o Scorecard The Pollution Information Site ${ }^{8}$, o perfil químico da platina metálica ${ }^{9}$, em diferentes bases de dados, indica suspeitas de toxicidade humana, nos sistemas: imune, respiratório, nervoso e, de órgãos do sentido. $\mathrm{Na}$ escala de risco ecológico esta forma apresenta menos periculosidade do que a maioria dos residuos perigosos, segundo a Waste Minimization Prioritization Tool - WMPT ${ }^{10}$ (FIG 6.8). Ressalta-se que para a Pt metálica não foram encontradas restrições legais de emissão.

Menos perigoso

Mais perigoso

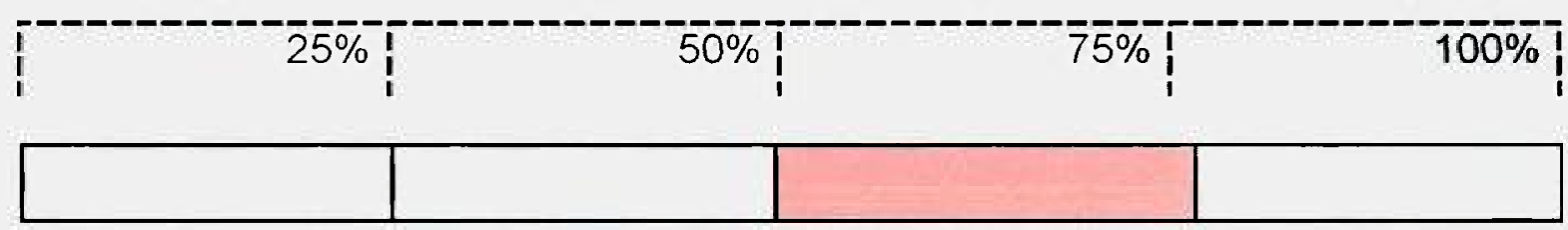

FIGURA 6.8 - Escala de risco ecológico

Fonte: Scorecard The Pollution Information Site

No entanto, no que tange aos compostos, a OSHA determina o limite de contaminantes no ar para sais de platina solúvel no valor de $0,002 \mathrm{mg} \mathrm{m}^{-3}$ (Occupational and Safety Health Act 1910/100011, 2001), sendo o dano imediato à vida ou a saúde humana para esta mesma forma de $\mathrm{Pt}$, no valor de $4 \mathrm{mg} \mathrm{m}^{-3}$ (NIOSH/OSHA, 1997).

No Brasil, ainda não foram estabelecidos limites de concentração especificos para a platina metálica e compostos na atmosfera, embora a resolução do Conselho Nacional do Meio Ambiente - CONAMA 03 de 1990 estabeleça padrões primários e secundários para particulas em suspensão e para inaláveis, o que de certa forma inclui os particulados de $\mathrm{Pt}$.

Neste panorama, a ausência de informações consolidadas e confiáveis sobre as influências das atividades, processos e produtos do ciclo de vida da platina, no meio ambiente e na saúde humana, também refletem na deficiência de restrições legais especificas. Embora os impactos relacionados à indústria da

\footnotetext{
"Disponivel em : http://www.scorecard.org/chemical-profiles/summary. Acesso em maio de 2006.

"Platina no estado de valência zero.

"Disponivel cm hup://www.epa.gor/epaoswer/ha/waste/minimize/chemlist.htm. Acesso $\mathrm{cm}$ maio de 20)6

${ }^{11}$ Disponivel cm hltp://www.osha.gor/pls/oshaweb Acesso em maio de 2006.
} 
mineração sejam mais conhecidos, o mesmo não ocorre com os dos demais setores. Ainda, segundo HSDB (2006), os procedimentos de disposição final são objeto de urgente revisão, visto a lacuna nas restrições legais e os possiveis efeitos no meio ambiente. Portanto, a identificação dos impactos relacionados ao ciclo de vida da platina evidencia a necessidade de uma gama de informações sobre os parâmetros técnicos de produção e gerenciamento final de cada setor de aplicação.

No caso da PEMFC, os impactos relacionados ao uso deste metal foram apontados no capítulo 4 , porém como a manufatura do MEA encontra-se em estágio piloto, é evidentemente clara a existência de incertezas quanto às cargas ambientais associadas à platina, já que as especificações dos equipamentos e métodos utilizados estão diretamente relacionados ao requerimento do material, assim como dos resíduos gerados e, conseqüentemente, aos efeitos ambientais.

\subsection{5 - Consideracões sobre a Etapa de Simplificacão}

Diante do cenário exposto na identificação das questões relevantes acerca da platina, no contexto da tecnologia PEMFC, é nitidamente fácil perceber as dificuldades de avaliar o ciclo de um produto ou processo. Assim, observa-se que um estudo completo da ACV somente pode ser conduzido à medida que cada indústria ou segmento industrial analisa e constrói representações das partes do ciclo total.

Partindo desta premissa, na fase de gerenciamento pós-uso dos catalisadores de platina da PEMFC (FIG 6.9), considerou-se como fator determinante na simplificação da ACV, a obtenção e tratamento dos dados primários e, os secundários obtidos nos estudos especificos já realizados (cf. cap. 4).

Por conseguinte, cabe ressaltar que a ACV estudada reflete apenas uma fração do ciclo do processo, já que outros sistemas estão inseridos, (como por exemplo, a produção de reagentes e equipamentos necessários), os quais não foram inclusos nesta avaliação 


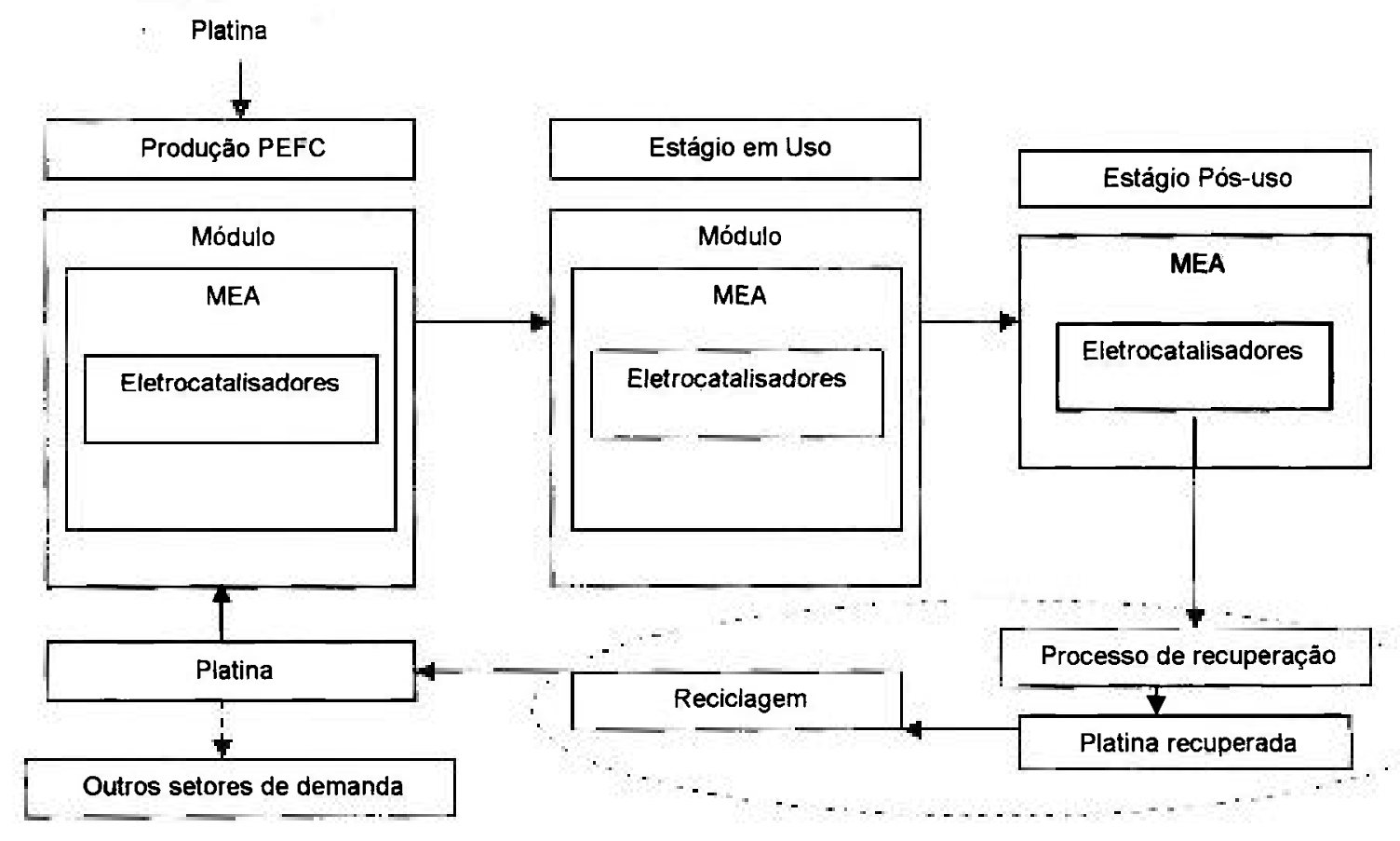

FIGURA 6.9 - Ciclo de vida da platina na PEMFC, foco na etapa de recuperação

Deste modo, os recortes no horizonte de análise do processo de recuperação dos catalisadores refletem as incertezas quanto aos aspectos de produção e destinação final da PEMFC, além de traduzirem a complexidade da $\mathrm{ACV}$ e dos fatores a ela inerentes. Conforme apresentado na metodologia, as fronteiras em relação aos outros sistemas circunscreveu-se apenas aos dados primários produzidos, porém no inventário as informações relativas à produção do MEA foram essenciais para efetuar o balanço de massa do material de estudo.

\subsection{Inventário: coleta e análise dos dados}

\subsection{1 - Processo Produtivo do MEA}

Segundo BALDO (2003), o processo de produção do conjunto eletrodo membrana desenvolvido no IPEN, sucintamente consiste em quatro etapas distintas: a) tratamento da membrana polimérica; b) preparação da tinta catalítica; c) produção dos eletrodos de difusão gasosa, pelo processo de spray; e d) prensagem a quente das camadas difusoras nas camadas catalíticas (FIG. 6.10). 


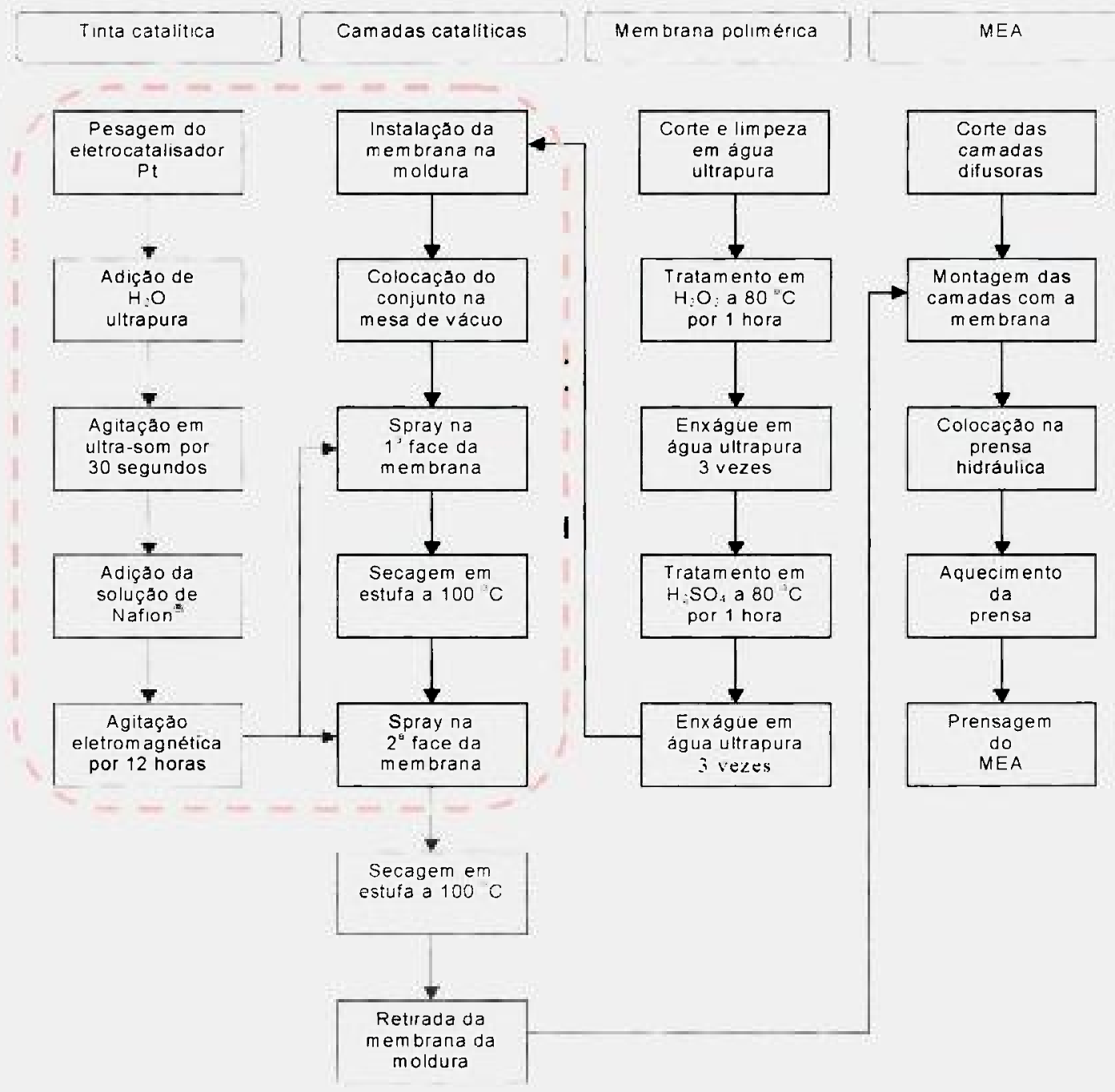

FIGURA 6.10 - Diagrama de blocos das etapas de preparação do MEA

Fonte: BALDO, 2003.

Para ACV deste estudo. os dados necessários, concentram-se na fase de preparação da tinta e da camada catalitica, cujas informações sobre a composição química, a carga e massa de catalisador em cada eletrodo são apresentados na TABELA 6.7 e 6.8 , respectivamente.

TABELA 6.7 - Composição da tinta catalítica

\begin{tabular}{|c|c|c|c|}
\hline ELEMENTO & QUANTIDADE & UNIDADE & OBSERVAÇÓES \\
\hline Água ultrapura & 4,0 & $\overline{\mathrm{mL}}$ & \multirow{3}{*}{$\begin{array}{l}\text { Platina ancorada em carbono ( } 20 \% \text { em massa } \\
\text { de metal) }\end{array}$} \\
\hline Dispersão de Nafion & 1,0 & $\mathrm{~mL}$ & \\
\hline Platina comercial & 0,2 & 9 & \\
\hline
\end{tabular}


TABELA 6.8 - Carga catalítica e massa estimada por eletrodo

\begin{tabular}{c|c|c|c|c}
\hline ELETRODO & CARGA & UNIDADE & MASSA ESTIMADA & UNIDADE \\
\hline Ánodo & 0,0004 & $\mathrm{~g} \mathrm{~cm}^{-2}$ & 0,0100 & $\mathrm{~g}$ \\
\hline Cátodo & 0,0006 & $-\frac{\mathrm{g} \mathrm{cm}^{-2}}{2}$ & 0,0150 & $\mathrm{~g}$ \\
\hline \multicolumn{5}{r}{ Área ativa da célula $25 \mathrm{~cm}^{2}$} \\
\hline
\end{tabular}

Conforme especificações técnicas do processo de produção dos eletrodos de difusão gasosa, a massa em porcentagem dos elementos da tinta catalítica na solução está estimada em $13,1 \%$ de $\mathrm{Pt} ; \quad 52,4 \%$ de carbono e $34,5 \%$ de ionômero (dispersão do Nafion® formada a partir do copolimero ácido perfluorsulfônico). Outros parâmetros, tais como: dimensões da membrana e das camadas difusoras (Carbon Cloth), utilizados na produção do MEA também foram coletadas, e são apresentados na TAB 6.9. Informações complementares sobre o método de preparação do MEA podem ser encontradas em BALDO (2003) e FREY \& LINARDI (2004).

TABELA 6.9 - Especificações do eletrólito e da camada difusora

\begin{tabular}{c|c|c|c|c}
\hline COMPONENTE & QUANTIDADE & DIMENSĀO & UNIDADE & ÄREA \\
\hline Eletrólito & 1 & $10 \times 10$ & $\mathrm{~cm}$ & $100 \mathrm{~cm}^{2}$ \\
\hline Camada Difusora & 2 & $5 \times 5$ & $\mathrm{~cm}$ & $25 \mathrm{~cm}^{2}$ \\
\hline
\end{tabular}

Os dados aqui obtidos permitiram identificar a quantidade $e$ as características dos materiais do MEA, produzindo informações úteis e essenciais para a coleta e análise dos dados do processo de recuperação. Destarte, o balanço de massa focou nesses materiais e o fluxo de referência consistiu na relação da massa catalítica estimada para a produção e a recuperação.

\subsubsection{Processo de Recuperacão}

Os resultados apresentados a seguir referem-se à coleta e análise dos dados do processo. Neste sentido, a TAB. 6.10 apresenta as informações relacionadas à etapa de pesagem do MEA's completos antes de entrarem no processo de recuperação e dos seus componentes na medida em que estes eram removidos do conjunto (cf . cap. 5). 
TABELA 6.10 - Valores obtidos na pesagem do MEA e dos seus componentes em gramas

\begin{tabular}{c|c|c|c|c}
\hline MEA & MASSA TOTAL & ELETRÓLITO & CAMADA DIFUSORA & CAMADA CATALITICA $^{{ }^{2}}$ \\
\hline 1 & 2,3470 & 1,2330 & 0,9032 & 0,2084 \\
\hline 2 & 2,2814 & 0,7446 & 0,8513 & 0,2684 \\
\hline 3 & 2,0279 & 0,8688 &,- 8602 & 0,1860 \\
\hline 4 & 2,3183 & 1,2011 & 0,9108 & 0,1281 \\
\hline 5 & 2,4035 & 1,2317 & 0,9115 & 0,1661 \\
\hline 6 & 2,3175 & 1,1467 & 1,0457 & 0,1013 \\
\hline 7 & 2,4114 & 1,3456 & 0,8593 & 0,1843 \\
\hline 8 & 2,2418 & 1,1158 & 0,8383 & 0,2580 \\
\hline 9 & 2,4109 & 1,3029 & 0,8949 & 0,1166 \\
\hline 10 & 2,3998 & 1,3087 & 0,8821 & 0,1957 \\
\hline 11 & 2,4046 & 1,3239 & 0,8817 & 0,1514 \\
\hline 12 & 2,4675 & 1,3454 & 0,8805 & 0,2400 \\
\hline
\end{tabular}

1- Camada catalitica composta por nanoparticulas de platina ancoradas em carbono (Carbon Black) recobertas por uma dispersão do Nafion @ (cf. cap. 2)

Para averiguar as saidas destes materiais no sistema e, particularmente, para mensurar a eficiência do processo, a massa do conjunto eletrodo membrana pesada inicialmente foi comparada com a massa final obtida pela somatória dos valores dos elementos do conjunto eletrodo membrana (TAB 6.11).

TABELA 6.11 - Comparação entre a massa inicial e final do MEA em gramas

\begin{tabular}{c|c|c|c}
\hline MEA & MASSA TOTAL INICIAL & MASSA TOTAL FINAL & DIFERENÇA DE MASSA \\
\hline 1 & 2,3470 & 2,3446 & 0,0024 \\
\hline 2 & 2,2814 & 1,8643 & 0,4171 \\
\hline 3 & 2,0279 & 1,9150 & 0,1129 \\
\hline 4 & 2,3183 & 2,2400 & 0,0783 \\
\hline 5 & 2,4035 & 2,3093 & 0,0942 \\
\hline 6 & 2,3175 & 2,2937 & 0,0238 \\
\hline 7 & 2,4114 & 2,3892 & 0,0222 \\
\hline 8 & 2,2418 & 2,2121 & 0,0297 \\
\hline 9 & 2,4109 & 2,3144 & 0,0965 \\
\hline 10 & 2,3998 & 2,3865 & 0,0133 \\
\hline 11 & 2,4046 & 2,3570 & 0,0476 \\
\hline 12 & 2,4675 & 2,4455 & 0,0220 \\
\hline
\end{tabular}

$\mathrm{Na}$ TAB 6.11, os valores encontrados na diferença de massa dos MEA's estão associados principalmente a perdas da camada catalitica, durante a remoção da camada difusora e do soluto na vidraria. Em segundo plano, 
também se referem à perda de água do eletrólito por desidratação após ser retirado da solução solvente e secar.

Devido à incerteza quanto ao método de produção de todos os MEA's procurou-se identificar as possiveis diferenças (massa) dos componentes. Assim, foram coletadas e pesadas amostras da membrana Nafion $®$ (eletrólito) e do tecido de carbono (camada difusora) nas mesmas dimensões utilizadas na produção do conjunto eletrodo membrana. Essas amostras, consideradas como padrão, foram comparadas com os respectivos elementos removidos do MEA's durante o processo de recuperação (TAB. 6.12 E 6.13).

TABELA 6.12 - Comparação entre a massa do eletrólito padrão $(P)$ e do eletrólito do obtido no processo (R) em gramas

\begin{tabular}{c|c|c|c}
\hline MEA & ELETRÓLITO (P) & ELETRÓLITO (R) & DIFERENÇA DE MASSA \\
\hline 1 & 1,7259 & 1,2330 & 0,4929 \\
\hline 2 & 1,7259 & 0,7446 & 0,9813 \\
\hline 3 & 1,7259 & 0,8688 & 0,8571 \\
\hline 4 & 1,7259 & 1,2011 & 0,5248 \\
\hline 5 & 1,7259 & 1,2317 & 0,4942 \\
\hline 6 & 1,7259 & 1,1467 & 0,5792 \\
\hline 7 & 1,7259 & 1,3456 & 0,3803 \\
\hline 8 & 1,7259 & 1,1158 & 0,6101 \\
\hline 9 & 1,7259 & 1,3029 & 0,4230 \\
\hline 10 & 1,7259 & 1,3087 & 0,4172 \\
\hline 11 & 1,7259 & 1,3239 & 0,4020 \\
\hline 12 & 1,7259 & 1,3454 & 0,3805 \\
\hline
\end{tabular}

TABELA 6.13 - Comparação entre a massa da camada difusora padrão $(P)$ e da camada obtida no processo $(R)$ em gramas

\begin{tabular}{c|c|c|c}
\hline MEA & CAMADA DIFUSORA (P) & CAMADA DIFUSORA (R) & DIFERENÇA DE MASSA \\
\hline 1 & 0,9292 & 0,9032 & 0,0260 \\
\hline 2 & 0,9292 & 0,8513 & 0,0779 \\
\hline 3 & 0,9292 & 0,8602 & 0,0690 \\
\hline 4 & 0,9292 & 0,9108 & 0,0184 \\
\hline 5 & 0,9292 & 0,9115 & 0,0177 \\
\hline 6 & 0,9292 & 0,9085 & 0,0207 \\
\hline 7 & 0,9292 & 0,8593 & 0,0699 \\
\hline 8 & 0,9292 & 0,8383 & 0,0909 \\
\hline 9 & 0,9292 & 0,8949 & 0,0343 \\
\hline 10 & 0,9292 & 0,8821 & 0,0471 \\
\hline 11 & 0,9292 & 0,8817 & 0,0475 \\
\hline 12 & 0,9292 & 0,8805 & 0,0487 \\
\hline
\end{tabular}


De tal modo, também comparou-se a massa teórica da camada catalítica, estimada a partir dos dados da produção do $\mathrm{MEA}^{12}$, com a massa obtida no processo de recuperação (TAB 6.14).

TABELA 6.14 - Comparação entre a massa da camada catalítica teórica $(T)$ e a camada obtida no processo $(R)$ em gramas

\begin{tabular}{c|c|c|c}
\hline MEA & CAMAdA CATALiticA (T) & CAMAdA CATALITICA (R) & DIFERENÇA DE MASSA \\
\hline 1 & 0,1908 & 0,2084 & $-0,0176$ \\
\hline 2 & 0,1908 & 0,2684 & $-0,0776$ \\
\hline 3 & 0,1908 & 0,1860 & 0,0048 \\
\hline 4 & 0,1908 & 0,1281 & 0,0627 \\
\hline 5 & 0,1908 & 0,1661 & 0,0247 \\
\hline 6 & 0,1908 & 0,1013 & 0,0895 \\
\hline 7 & 0,1908 & 0,1843 & 0,0065 \\
\hline 8 & 0,1908 & 0,2580 & $-0,0672$ \\
\hline 9 & 0,1908 & 0,1166 & 0,0742 \\
\hline 10 & 0,1908 & 0,1957 & $-0,0049$ \\
\hline 11 & 0,1908 & 0,1514 & 0,0394 \\
\hline 12 & 0,1908 & 0,2400 & $-0,0492$ \\
\hline
\end{tabular}

Basicamente, as diferenças encontradas nas TAB 6.12 e TAB 6.13 estão relacionadas a variações nas dimensões do eletrólito e da camada difusora; associadas, a principio, ao corte manual e a etapa de montagem do MEA na célula, durante o processo produtivo, bem como aos fatores relacionados à sua remoção e, desmonte do conjunto eletrodo membrana. Dada as limitações do estudo, para a análise do inventário as variáveis relacionadas à etapa anterior a recuperação não foram consideradas.

Em relação a TAB 6.14, as diferenças de massa estão vinculadas a dois aspectos, ambos pertinentes a técnica de manufatura do MEA. O primeiro diz respeito à fase na qual a tinta catalítica é aplicada, por spray, nas faces da membrana, comumente pequenas variações na carga (na ordem de $10^{-2} \mathrm{mg}$ ) ocorrem durante este processo.

O segundo trata das questões relacionadas ao objetivo da carga catalítica. Como o IPEN tem trabalhado no desenvolvimento de vários métodos de produção dos eletrodos de difusão gasosa - EDG (cf. cap. 5), MEA's com diferentes cargas

\footnotetext{
${ }^{1 *}$ Massa teórica de platina $(0,0250 \mathrm{~g})$, carbono $(0,1000 \mathrm{~g})$ e de ionômero $(0,0658 \mathrm{~g})$ no MEA. estimada a partir da carga catalítica e sua relação percentual com o carbono e a dispersão do Nafion (î̉) .
} 
são produzidos para fins de teste. Essas podem variar de $0,2 \mathrm{mg} \mathrm{cm}^{-2}$ a $0,4 \mathrm{mg}^{-2}$ no ânodo e de $0,2 \mathrm{mg} \mathrm{cm}^{-2}$ a $0,6 \mathrm{mg} \mathrm{cm}^{-2}$ no cátodo. Esses aspectos são importantes e foram considerados para quantificar a massa de platina e mensurar a eficiência do processo.

Por conseguinte, o cálculo da quantidade de platina e dos demais elementos da camada catalítica foi efetuado a partir do percentual dado na composição da tinta catalítica em função da massa total deste material obtido no processo de recuperação (TAB 6.14) e não em função da sua masșa padrão total no MEA.

Sendo assim, para a etapa das análises (cf. cap. 5), as massas resultantes na recuperação de cada MEA foram compostas de três em três formando quatro amostras, nas quais foram estimadas a quantidade $(\mathrm{m})$ dos seus três principais componentes (TAB 6.15).

TABELA 6.15 - Massa estimada para os elementos da camada catalítica obtida no processo de recuperação em gramas

\begin{tabular}{c|c|c|c}
\hline MEA & PLATINA & CARBONO & IONÔMERO \\
\hline 1 & 0,0273 & 0,1092 & 0,0721 \\
\hline 2 & 0,0352 & 0,1406 & 0,0929 \\
\hline 3 & 0,0244 & 0,0975 & 0,0644 \\
\hline 4 & 0,0168 & 0,0671 & 0,0443 \\
\hline 5 & 0,0218 & 0,0870 & 0,0575 \\
\hline 6 & 0,0133 & 0,0531 & 0,0350 \\
\hline 7 & 0,0241 & 0,0966 & 0,0638 \\
\hline 8 & 0,0338 & 0,1352 & 0,0893 \\
\hline 9 & 0,0153 & 0,0611 & 0,0403 \\
\hline 10 & 0,0256 & 0,1025 & 0,0677 \\
\hline 11 & 0,0198 & 0,0793 & 0,0524 \\
\hline 12 & 0,0314 & 0,1258 & 0,0830 \\
\hline
\end{tabular}

TABELA 6.16 - Perfil das amostras encaminhadas para análises em gramas

\begin{tabular}{c|c|c|c|c}
\hline MEA & MASSA TOTAL & PLATINA & CARBONO & IONÔMERO \\
\hline $1 ; 2 ; 3$ & 0,6628 & 0,0868 & 0,3473 & 0,2287 \\
\hline $4 ; 5 ; 6 ;$ & 0,3955 & 0,0518 & 0,2072 & 0,1364 \\
\hline $7 ; 8 ; 9 ;$ & 0,5589 & 0,0732 & 0,2929 & 0,1928 \\
\hline $10 ; 11 ; 12$ & 0,5867 & 0,0769 & 0,3074 & 0,2024 \\
\hline \hline Total & 2,2039 & 0,2887 & 1,1548 & 0,7603 \\
\hline
\end{tabular}


Com base nas informações geradas nesta etapa e nos dados da ficha de coleta construiu-se o diagrama do inventário, apresentado na FIG 6.11. Contudo, em relação ao consumo de energia, o cálculo foi realizado em função do uso de equipamentos no processo ${ }^{13}$. Desta maneira não foi contabilizada a utilização da energia necessária para iluminação do ambiente e tampouco para as análises efetuadas na checagem dos dados e verificação do produto (cf. cap..5).
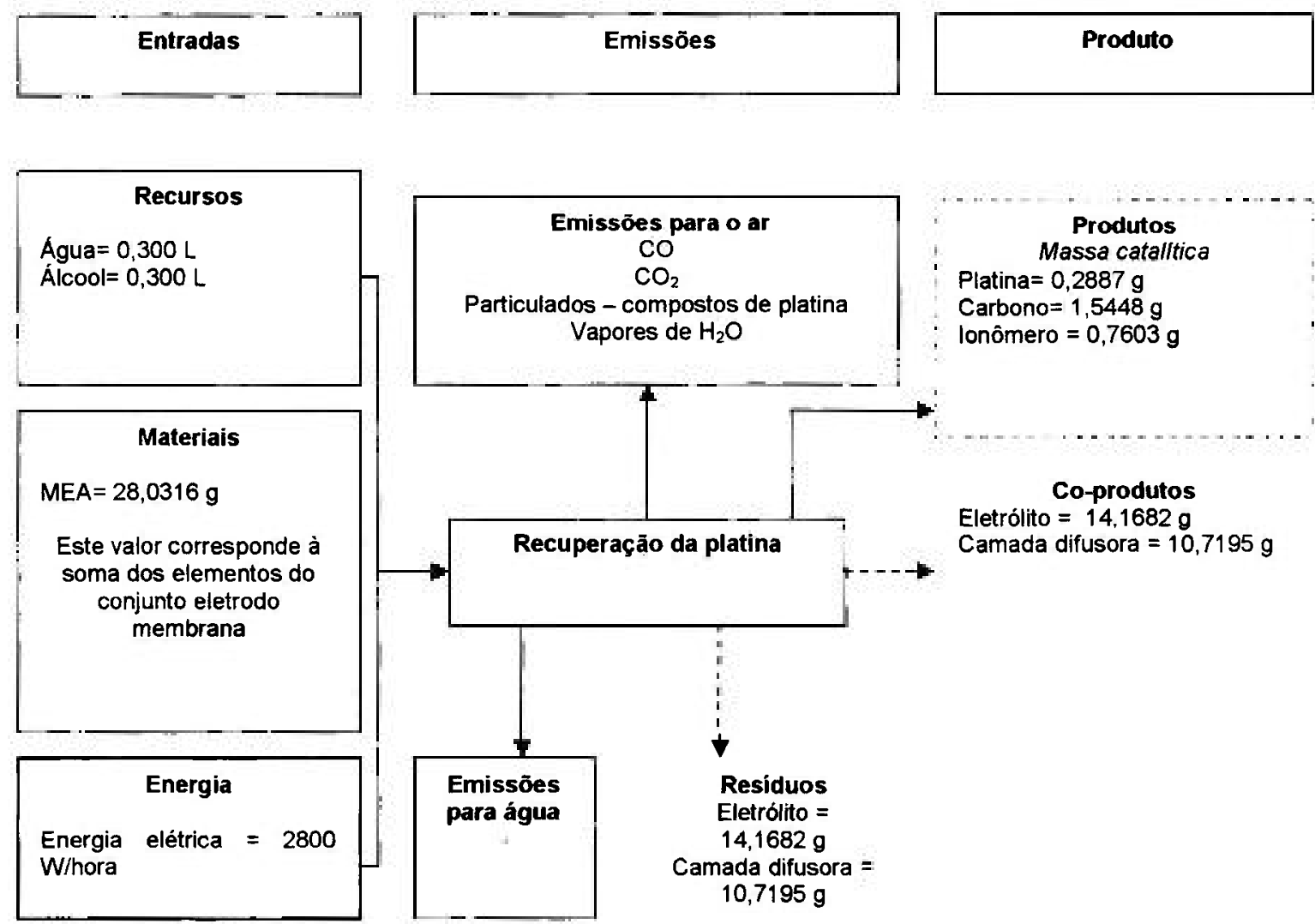

FIGURA 6.11 - Inventário do processo de recuperação

Tendo em vista que a análise de impactos da ACV não contempla a etapa de quantificação do perfil de depleção (o quanto cada emissão contribui para as categorias de impactos selecionadas), os dados relacionados às emissões para o meio ambiente não foram quantificadas. Quanto às outras saídas do sistema, cabe ressaltar que no caso da membrana e da camada difusora, do ponto de vista de interesse do processo, estes elementos podem ser considerados resíduos. Em

13 Equipamentos: capela marca QUIMIS modelo Q 216-11 (100W) e placa magnética agitadora aquecedora (400) marca QUIMIS modelo Q 26112 . Cálculo de Energia elétrica = Potência (watts) * hora. O tempo médio de uso durante o processo para ambos foi de 4 horas. 
outra instância, ponderando o custo das membranas e a tendência crescente de padrões mais rígidos de controle ambiental, tais componentes podem ser visualizados como co-produtos. No que tange ao produto obtido, foram realizadas análises para verificação quanto à quantidade e características, os resultados dessas são apresentados no item 6.2.3.

Segundo apresenta a metodologia, outros procedimentos também foram efetuados para elaborar o inventário, dentre estes, cabe salientar que em relação ao software de ACV, verificou-se que no seu banco de dados existem diversos materiais e produtos inventariados, métodos para calcular o consumo de energia e recursos naturais, transporte, entre outros aspectos relacionados a $A C V$, como por exemplo, técnicas de avaliação dos impactos resultantes do processo ou de um determinado produto.

A partir de informações, dados e parâmetros especificos ${ }^{14}$ inseridos pelo usuário, o software realiza as análises necessárias (ICV, AICV), verifica as questões relacionadas quanto à sensibilidade e consistência, bem como gera gráficos, tabelas e o relatório final. Embora não tenha sido possível utilizá-lo para realizar a este estudo ${ }^{15}$, esta ferramenta pode auxiliar significativamente a executar a $\mathrm{ACV}$, e remover as tensões entre praticidade e precisão.

\subsubsection{Análises de Verificacão: eficiência do processo}

As técnicas utilizadas para a checar os resultados do inventário, nomeadamente em relação à quantidade de platina, e verificar a eficiência da recuperação desse metal foram: análise termogravimétrica - ATG, espectrometria de fluorescência de raios $X$ - FRX e análise de ativação neutrônica - ATN Contudo, apenas os resultados obtidos na ATG e na ATN serão apresentados, pois os dados relativos a FRX, foram úteis apenas para indicar a presença do metal nobre; fato peculiar ao material do MEA. Neste sentido, os resultados das técnicas escolhidas são apresentados a seguir.

\footnotetext{
${ }^{14}$ Tais como: dados da empresa, produto a ser estudado; processos envolvidos; quantidade de material, entre outros.

${ }^{15}$ Principalmente por possuir limitações para o uso.
} 
Os resultados na ATG do produto obtido no processo (camada catalítica), permitiram observar que as perdas de massa totalizaram em torno de $89,42 \%$, este valor corresponde essencialmente à decomposição térmica do material orgânico e substâncias inorgânicas (basicamente ácido perfluorosulfônico). Desta forma, a massa residual constitui-se no elemento metálico presente na amostra, cujo percentual encontra-se por volta de 10,58\%(FIG. 6.12).

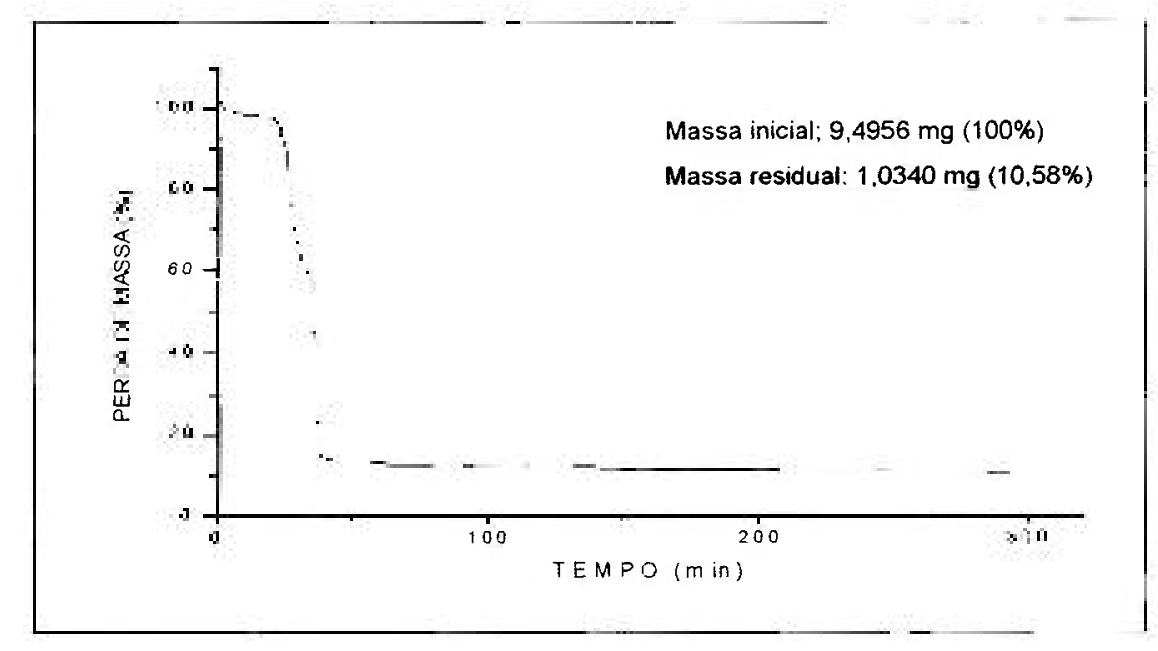

FIGURA 6.12 - Curva da ATG para a massa catalítica

Para fins de comparação amostras da tinta catalítica (pó) e da platina comercial $^{16}$ também foram analisadas. Observou-se que o resultado encontrado na ATG da tinta foi similar ao da camada catalítica, pois a massa residual foi em torno de $11,19 \%$ (FIG. 6.13). Em ambas as amostras a decomposição térmica estabilizou-se a partir de $536^{\circ} \mathrm{C}$.

Em relação à platina comercial, de acordo com especificações técnicas do fabricante ${ }^{17}$, o percentual de metal presente na matriz de carbono encontra-se em torno de $20 \%$ (cf. TAB 6.7). Para verificar a coerência dos resultados encontrados nas duas amostras anteriores, este material foi encaminhado para a ATG, sob as mesmas condições de ensaio. O resultado obtido indicou que a estabilização da decomposição térmica ocorreu a partir $625^{\circ} \mathrm{C}$ e a perda de massa totalizou em $83 \%$ (FIG. 6.14), de forma que o percentual de massa residual

${ }^{16}$ Cabe ressaltar que em todas as análises a tinta catalítica foi considerada como padrão de referência para as amostras da camada catalítica, enquanto a platina comercial como padrão primário para essas duas .

${ }^{\overline{7}}$ VULCAN XC-72 - . Disponivel em http://www.etek-inc.com/standard/product_NMC.php?prodid=59 
encontrou-se dentro do que é comumente obtido na ATG desse material em específico ${ }^{18}$. Face a este quadro, pode-se inferir que os dados encontrados nas ATG da camada catalítica e da tinta são pertinentes para o estudo, pois são coerentes com o percentual de massa estimada para tais materiais e apresentam uma boa correlação entre seus valores e a platina comercial.

Neste caso, ao comparar o percentual de massa residual obtido na tinta $(11,19 \%)$ em relação ao da massa catalítica $(10,58 \%)$, o valor estimado para a recuperação encontra-se por volta de $94 \%$, o que significa uma perda de 0,61\% deste material no processo.

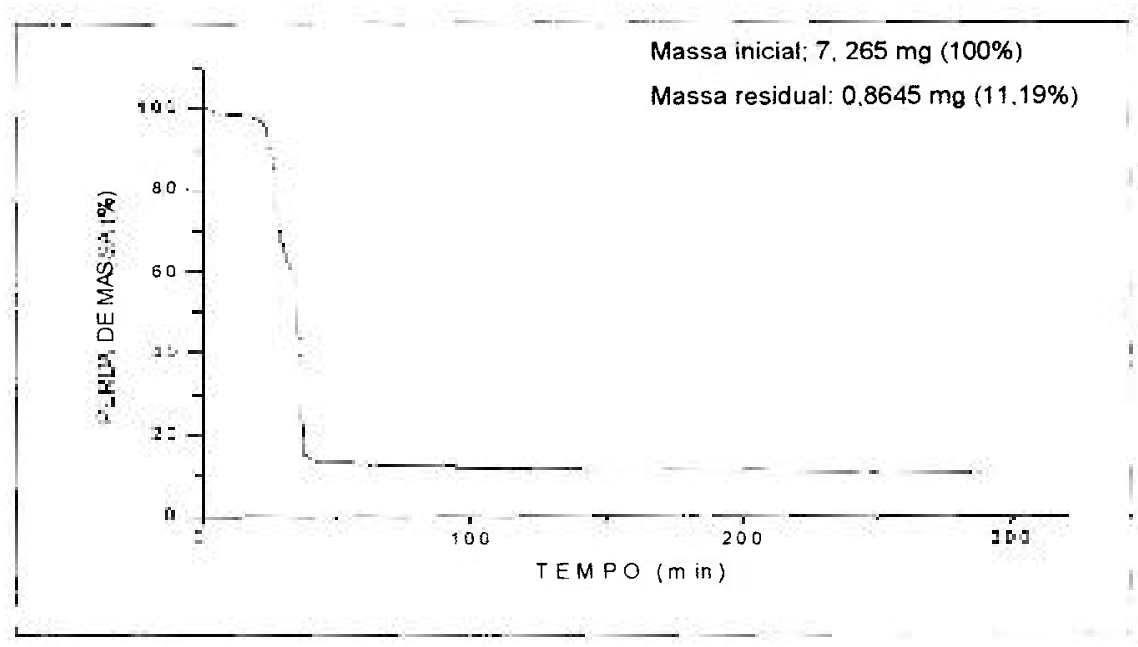

FIGURA 6.13 - Curva da ATG para a tinta catalítica

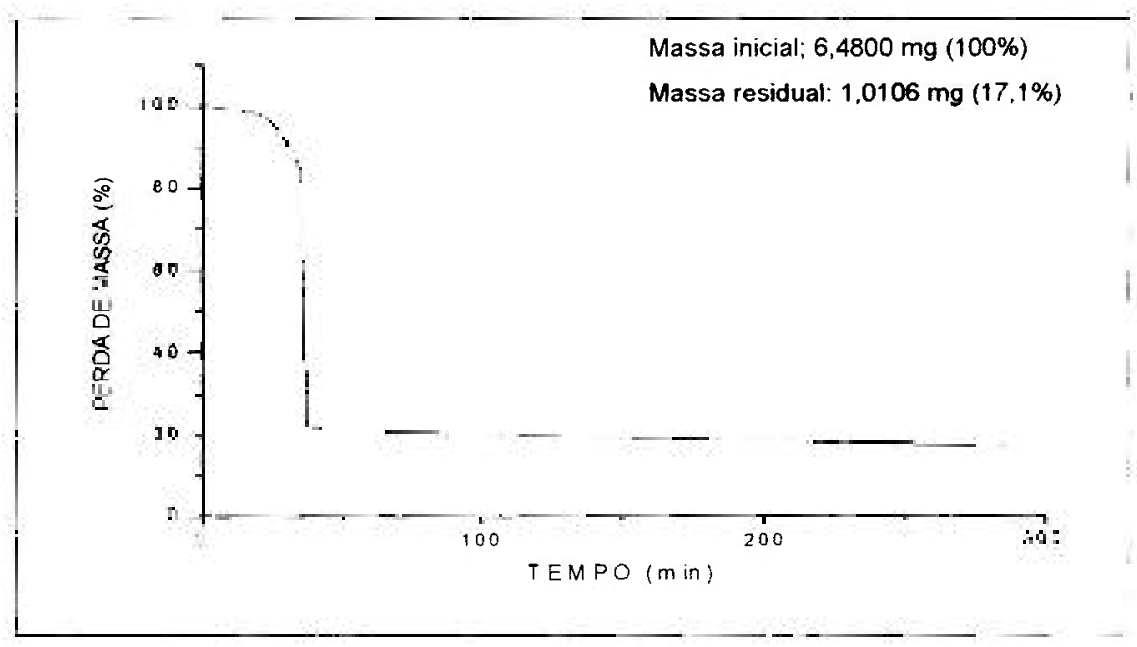

FIGURA 6.14 - Curva da ATG para a platina comercial

${ }^{18}$ SPINACÉ, E. Comunicação pessoal. Instituto de Pesquisas Energéticas e Nucleares/ IPEN, Centro de Ciência e Tecnologia de Materiais CCTM. Laboratório de Células a Combustivel, 2006. 
Todavia, considerando que a massa residual obtida na ATG constitui-se na platina metálica e, nas amostras analisadas é possivel encontrar platina na forma de compostos, uma averiguação quanto a sua concentração independente da sua forma química tornou-se necessária.

Neste sentido, as amostras da camada e da tinta catalítica, assim como a platina comercial, foram encaminhadas para a análise de ativação neutrônica ATN. Os valores obtidos quanto ao percentual de metal nobre na camada catalítica e na tinta também foram semelhantes, entretanto, distintos aos encontrados na ATG, o mesmo ocorreu em relação à platina comercial. Na TAB 6.16 são apresentados os resultados da determinação de platina e outras impurezas.

TABELA 6.17 - Determinação da platina e outras impurezas

\begin{tabular}{|c|c|c|c|}
\hline ELEMENTOS & CAMADA CATALITICA & TINTA CATALITICA & PLATINA COMERCIAL \\
\hline Bromo $\mu \mathrm{g}^{-1}$ & $1,87 \pm 0,08$ & $1,30 \pm 0,04$ & ND \\
\hline Cobalto $\mu \mathrm{g}^{-1}$ & $0,76 \pm 0,04$ & $32,3 \pm 0,9$ & ND \\
\hline Cromo $\quad \mu^{-1}$ & $46,3 \pm 0,9$ & $43,2 \pm 3,8$ & $\overline{1,7} \pm \overline{0,3}$ \\
\hline Ferro $\quad \mu g^{-\top}$ & $257 \pm 10$ & $187 \pm 18$ & $55 \pm 4$ \\
\hline Lantânio ${\mu \mathrm{g}^{-1}}^{-1}$ & $\overline{8,77 \pm 0, \overline{11}}$ & $0,258 \pm 0,008$ & $0,32 \pm 0,02$ \\
\hline Sódio & $324 \pm 6$ & $99,6 \pm 1,1$ & $N D$ \\
\hline Escândio $\mu \mathrm{g}^{-1}$ & $21,4 \pm 1,0$ & ND & $8,2 \pm 0,5$ \\
\hline Zinco $\mu \mathrm{g}^{-1}$ & $\overline{37,1 \pm 37,1}$ & $159,6 \pm 2,4$ & $\mathrm{ND}$ \\
\hline Platina $\quad \%$ & $22,10 \pm 0,09$ & $23,34 \pm 0,06$ & $33,3 \pm 0,1$ \\
\hline Iridio $\quad \mathrm{\mu g}^{-1}$ & ND & $0,195 \pm 0,001$ & $\overline{N D}$ \\
\hline Potássio $\mu \mathrm{g}^{-}$ & ND & $829 \pm 31$ & $\overrightarrow{N D}$ \\
\hline
\end{tabular}

N.D-Indica que o elemento não foi detectado

Observou-se que os percentuais de platina obtidos na ATN são exatamente o dobro dos encontrados na ATG, o que permite constatar, além da presença de outras formas de platina, que as amostras apresentaram diferenças proporcionalmente similares nas duas análises, de tal maneira que a eficiência de recuperação mensurada, a partir dos dados da ATG, são iguais a da ATN (percentual da camada em relação à tinta catalítica).

Não obstante, verificou-se que o caráter preciso da análise da ativação neutrônica, quanto à determinação de elementos independentes da sua 
configuração química, é relevante e, neste caso, para a checagem do produto obtido quanto à sua massa específica deve-se considerar a porcentagem de platina na camada catalítica dada nessa análise.

No que tange aos outras substâncias detectadas na ATN, a presença de cobalto e cromo são esperadas após o uso do material (catalisador) no cátodo ${ }^{17}$, em relação aos demais, outros fatores relacionados a parâmetros de preparação da tinta, condições de uso na célula e tratamento no processo podem estar relacionadas.

No entanto, estas questões constituem-se em uma outra investigação, e não no objeto de atenção deste estudo. Ademais, cabe ressaltar que a determinação dos elementos na ATN não inclui o carbono e o flúor ${ }^{19}$ (FIG 6.15), cuja quantidade nessas amostras são significativas (com exceção do F na platina comercial).

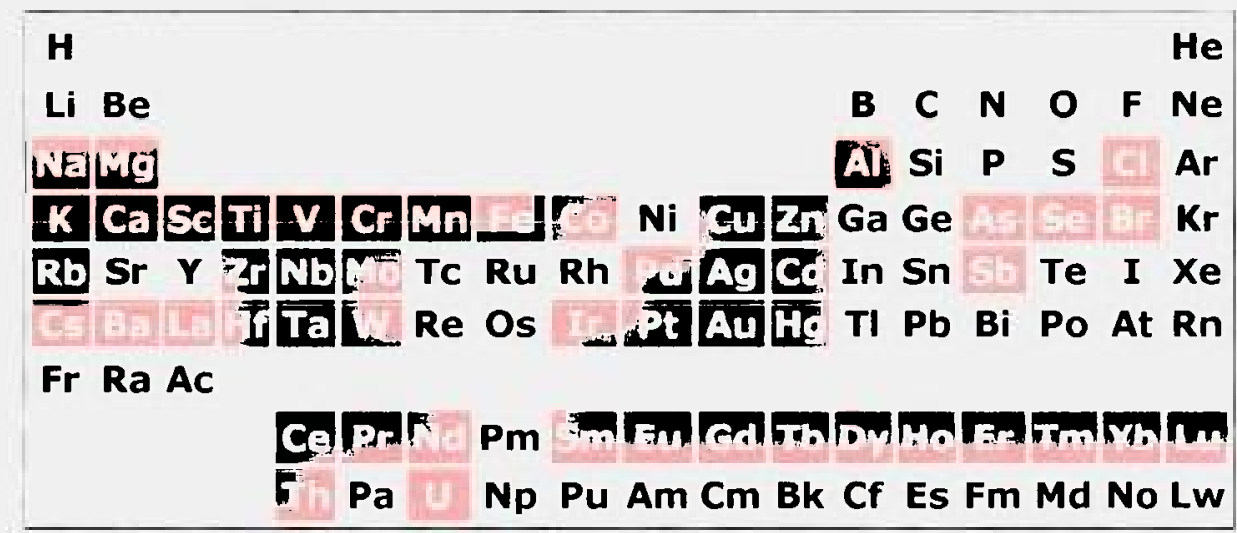

FIGURA 6.15 - Elementos detectados pela análise de ativação neutrônica Fonte: Laboratório de Análise por Ativação Neutrônica - LAN /IPEN

Por fim, diante dos resultados obtidos nas duas análises pode-se observar uma expressiva eficiência na recuperação de platina no processo $(94 \%)$, de tal forma que para verificar o potencial de reciclagem primária, ou seja, a reinserção deste material dentro do próprio sistema produtivo da PEMFC duas análises foram realizadas, as quais se configuram pela difração de raios $X-D R X$ e ciclovoltametria cíclica - VC, discutidas a seguir.

\footnotetext{
${ }^{19}$ Presente na dispersào do Nafion $\widehat{\mathbb{B}}$.
} 


\subsection{4- Análises de Caracterizacão: potencial de reciclagem}

$A$ análise de difração de raios $X$ permite, entre outros, avaliar o tamanho das partículas dos metais, parâmetro especialmente importante para os catalisadores ancorados em carbono utilizados na produção do MEA da célula PEMFC. Nesta análise, tal como nas anteriores, foram encaminhadas as mesmas amostras. As figuras $6.16,6.17$ e 6.18 mostram os difratogramas obtidos na camada catalítica, tinta e platina comercial, após o ajuste gaussiano realizado para eliminar os sinais correspondentes aos ruidos.

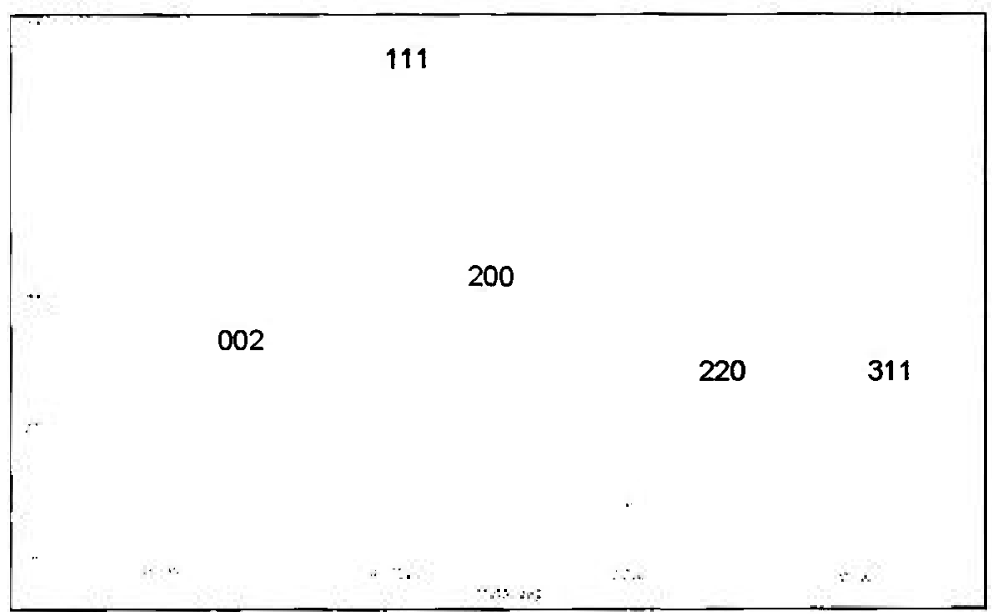

FIGURA 6.16 - Difratogramas de raios X para a camada catalítica

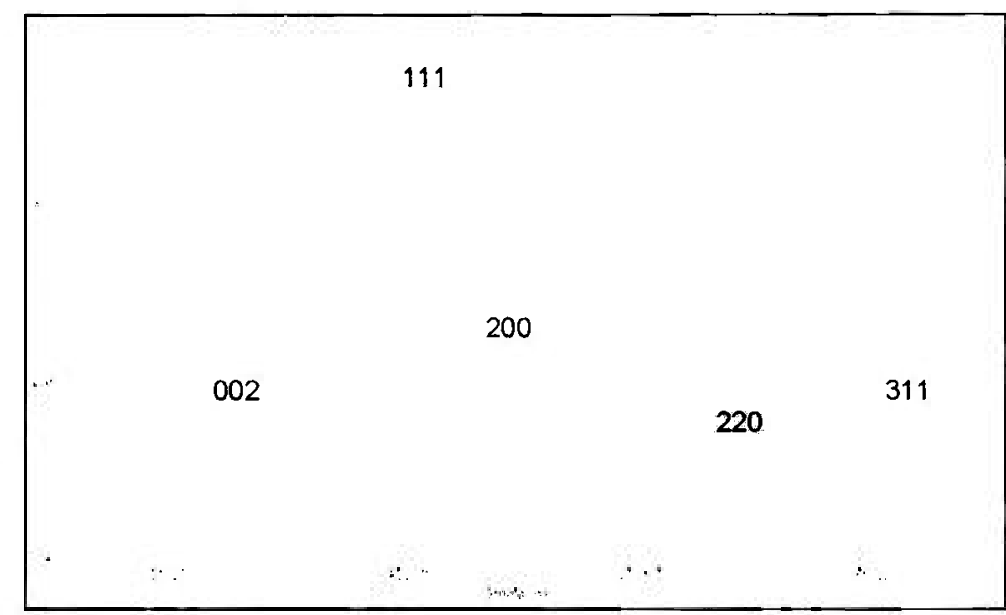

FIGURA 6.17 - Difratogramas de raios $X$ para tinta catalitica 


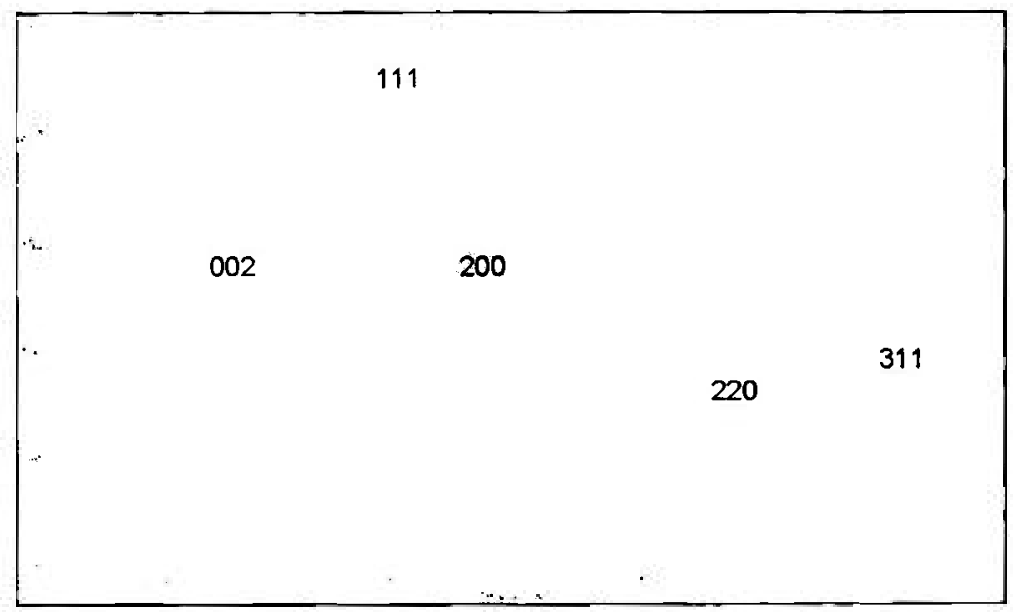

FIGURA 6.18 - Difratogramas de raios X para a platina comercial

Observa-se que em todos difratogramas ocorrem a presença de picos poucos intensos em $2 \Theta=25,46,67$ e 81, correspondentes aos planos (002), (200), (220) e (311), e um pico intenso em $2 \Theta=40$, equivalente ao plano (111). Portanto, é possivel verificar que as amostras da camada catalitica e da tinta apresentam os planos encontrados na platina comercial e, segundo SALGADO \& GONZALEZ (2003), caracteristicos de estruturas policristalinas da platina (200); (220); (311) e da estrutura de cúbica de face centrada da Pt pura (111), além da face de difração correspondente ao carbono (002).

Desta forma, o tamanho médio das partículas de platina nas amostras foi determinado por DRX empregando a equação de Scherrer (LUNA et. al, 2000). Neste caso, o pico (111) da estrutura cúbica de face centrada da platina foi escolhido para os cálculos. Os resultados obtidos para a platina comercial, tinta e camada catalítica foram, respectivamente, $2,62 d_{D R X} / n m, 3,15 d$ DRX $/ \mathrm{nm}$ e 3,85d $\mathrm{DRX} / \mathrm{nm}$.

Tais resultados foram comparados com os dados existentes na literatura (ibidem, 2003, p. 82) sobre a análise do diâmetro médio ( $\left.d_{D R X} / n m\right)$ das partículas do catalisador de platina, utilizadas na PEMFC, preparados por diferentes técnicas e, da platina comercial (TAB 6.16). Segundo STARZ et. al (1999) o diâmetro médio das partículas é de $2,5 \mathrm{~nm}$. 
TABELA 6.18 - Diâmetro médio das partículas de catalisadores de platina preparados por diferentes técnicas

\begin{tabular}{l|c|c|c|c|c}
\hline Método & Ácido fórmico & Watanabe et al (1985) & Borohidreto & Shukla et. al (2001) & Pt comercial ' \\
\hline$d_{\text {DRx }}$ (nm & 4,5 & 5,4 & 4,4 & 9,8 & 2,8 \\
\hline 1-Platina ETEK $(20 \%$ em massa de metal) & & & \\
\hline
\end{tabular}

Fonte: SALGADO \& GONZALEZ (2003)

Deste modo, é possível observar que os valores encontrados na tinta catalítica e na camada são inferiores aos mencionados nos métodos citados e situam-se mais próximos do diâmetro médio da platina comercial, o que é favorável, uma vez que o tamanho da partícula desempenha um papel importante na cinética de reação de redução de oxigênio (ibidem, 2003, p.73).

Contudo, a determinação da área eletroquimicamente ativa torna-se necessária, uma vez que as diferenças, entre os diâmetros das partículas da camada catalítica e da tinta, relacionados aos precursores usados nos seus respectivos processos (produção e recuperação) e a pureza dos materiais, influenciam o desempenho do catalisador .

Sendo assim, as três amostras foram encaminhadas para a análise de voltametria cíclica - VC. Os voltamogramas cíclicos em meio ácido para a tinta e a camada catalítica exibiram perfis característicos da platina policristalina ancorada em carbono (PEREZ et. al, 1998) como ilustra a FIG. 6.19. Nesses materiais observam-se picos pouco definidos na região de adsorção e dessorção de hidrogênio, compreendida entre 0,100 e 0,300 V vs ERH.

De acordo com SALGADO \& GONZALEZ (2003), os picos se bem definidos, seriam atribuidos a dessorção de átomos de hidrogênio provenientes de sítios de platina com rede cristalina bem definida e também caracteristicos de partículas menores. Por se tratar de materiais constituidos de particulas de diversos diâmetros, ancorados em carbono e envolvidos por uma dispersão do Nafion ${ }^{\circledR}$, não se pode esperar uma melhor resolução dos picos. 


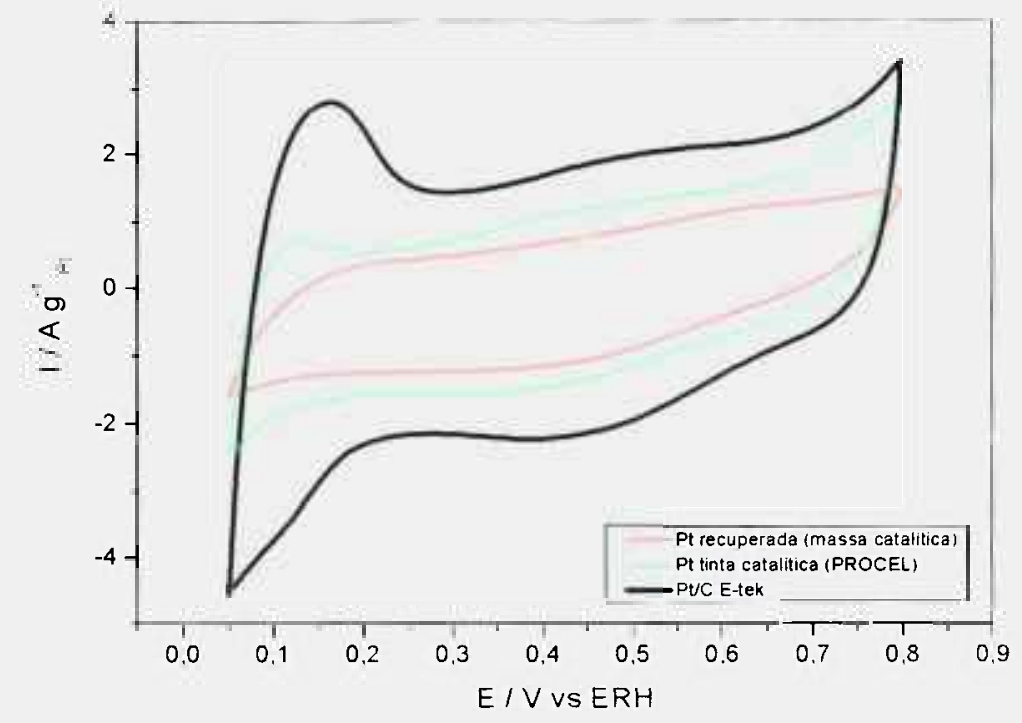

FIGURA 6.19 - Voltagramas cíclicos para a massa catalítica, tinta e platina comercial em meio ácido $0,5 \mathrm{~mol} \mathrm{~L}^{-1} \mathrm{H}_{2} \mathrm{SO}_{4}$

Também se observa uma diminuição nas densidades de corrente para a tinta e a camada em relação à platina comercial (ver FIG 6.19), que podem estar relacionadas a uma menor área eletroquimicamente ativa, como conseqüência de diversos aspectos tais como: tamanhos das partículas; quantidade de platina, além de substâncias impregnadas na superfície que impedem uma boa dispersão do catalisador ${ }^{20}$ (por exemplo, o ionômero).

Por conseguinte, tais aspectos indicam que uma menor quantidade da platina presente no eletrodo está sendo efetivamente utilizada no processo eletroquímico. Ademais, a presença de impurezas devido ao método de produção ou armazenamento da tinta e da recuperação da platina (além do material recuperado ser obtidos de MEA's usados), resultariam em um decréscimo da área de adsorção e conseqüente dessorção de hidrogênio ${ }^{18,20}$.

Não obstante, verifica-se que o desempenho da camada catalítica é nitidamente inferior aos demais porém, isto também está relacionado ao fato do 
material não sofrer nenhum tratamento para a remoção da dispersão do Nafion ${ }^{\circledR}$ (após o processo de recuperação), por sua vez justificável pela pouca quantidade de material e por envolver processos pirometalúrgicos, nos quais são essenciais sistemas de captura de gases, devido à eliminação de ácido fluoridrico. Ademais, em tais tratamentos são reconhecidos os impactos e a baixa eficiência em relação aos catalisadores de platina da PEMFC (cf. cap. 5).

Sendo assim, outras técnicas para avaliar a morfologia da superfície, estimar a distribuição do tamanho das partículas de platina ancorada em carbono (camada e tinta) e, principalmente, para determinar a concentração de flúor e questões correlatas, tornam-se necessárias na identificação dos elementos que influenciam o desempenho do material e na busca por melhorias no método de recuperação.

Destarte, a determinação do potencial de reciclagem envolve o futuro aprimoramento do processo para remover as variáveis relacionadas ao estudo exploratório e as que interferem a atividade catalitica do material recuperado. Conseqüentemente, as informações aqui apresentadas constituem-se em um passo inicial na direção de rotas alternativas que visem minimizar os impactos ambientais e econômicos relacionados a esse metal no ciclo de vida da PEMFC, e que por fim, configuraram úteis para verificar, mesmo parcialmente, as entradas e saidas do processo e, a medida de eficiência. Desta forma, a etapa final dos resultados da $A C V$, apresenta e discute a avaliação de impactos ambientais do processo.

\section{3 - Avaliação de Impactos do Ciclo de Vida do Processo}

\subsection{1 - Identificacão de Aspectos e Impactos}

A partir dos dados inventariados e com base nos estudos encontrados na literatura sobre os impactos relacionados à platina (cap. 4 e seção 6.1.4) foi possivel identificar quais os elementos do processo de recuperação podem interagir com o meio ambiente e produzir impactos significativos. Assim, os 
aspectos ambientais foram definidos a partir das atividades circunscritas ao processo e dentro das fronteiras estabelecidas para a esta avaliação do ciclo de vida, tais aspectos se configuraram basicamente pelo consumo de água, energia, emissões para o ar e residuos. A FIG. 6.20 ilustra as atividades nas quais são identificados os aspectos ambientais.

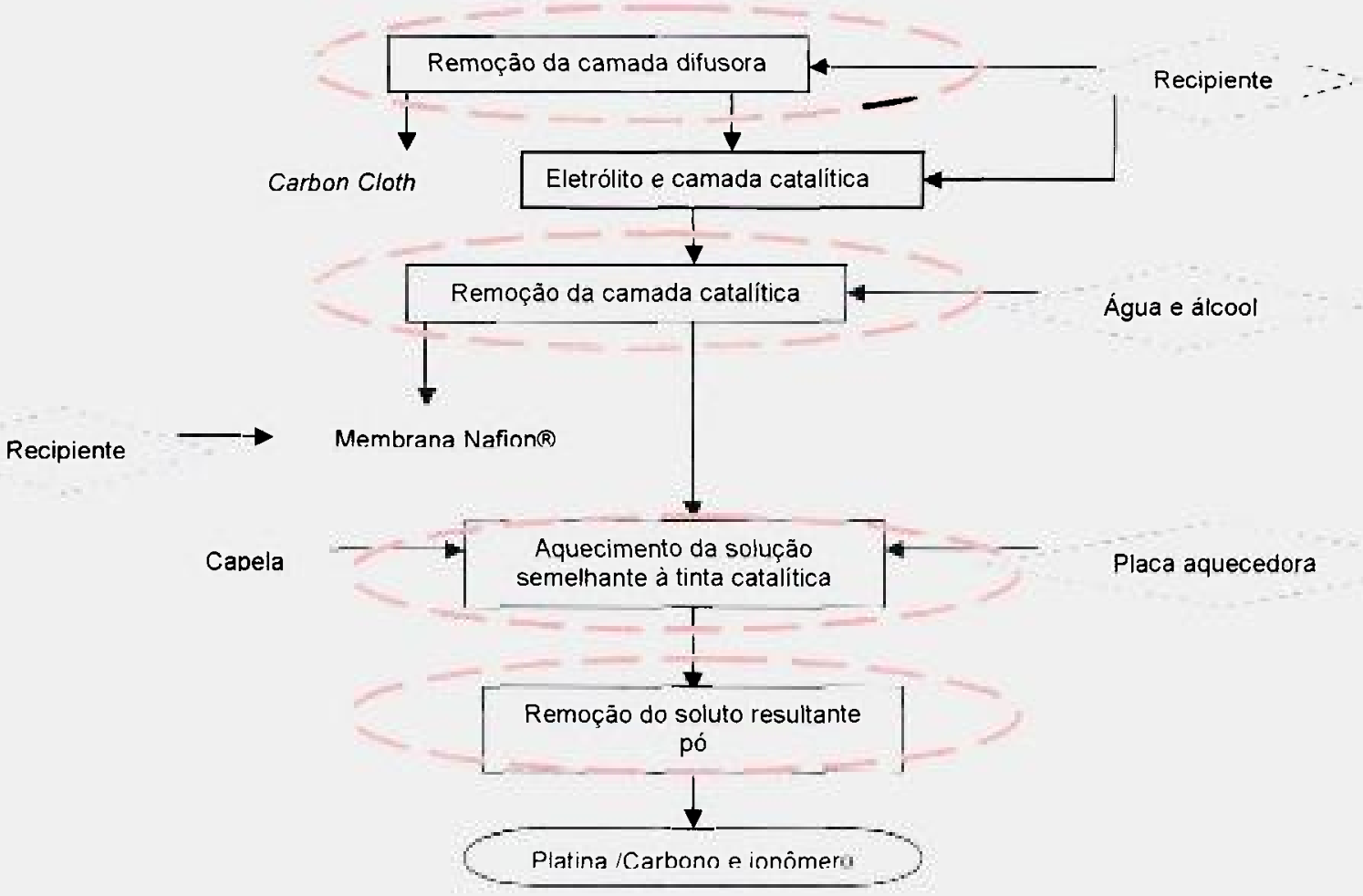

FIGURA 6. 20 - Atividades do processo de recuperação nas quais são identificados os aspectos ambientais

No que diz respeito aos impactos, sua definição considerou o potencial de produzir efeitos no meio ambiente; por conseguinte, foram estabelecidos pela: contaminação do ar, da água, do solo e depleção de recursos naturais. Neste caso, é importante compreender que tal acepção não inclui uma visão da magnitude (cf. cap. 5), uma vez que é essencial estabelecer o grau de alteração de um atributo ambiental e o conceito de qualidade nos compartimentos afetados em uma determinada localidade 
De tal maneira, o termo contaminação implica apenas em uma ponderação qualitativa e subjetiva dos aspectos e, exclui questões pertinentes, como por exemplo, a quantificação da gravidade. Ademais, tais aspectos podem ser alocados em mais de uma categoria de impacto, o que embora tenha sido considerado nesta avaliação, limitou-se a uma visão superficial das possibilidades de efeitos, dada a abrangência desta AICV (cf. cap. 5). A TAB 6.19 apresenta o resultado obtido na identificação das atividades, aspectos e impactos.

TABELA 6.19 - Identificação de atividades, aspectos e potenciais impactos

\begin{tabular}{c|c|c}
\hline ATIVIDADE & ASPECTO AMBIENTAL & POTENCIAL IMPACTO \\
\hline \multirow{2}{*}{ Remoção da Camada Difusora } & Particulados de platina & Contaminação do ar,água e solo \\
\cline { 2 - 3 } & Resíduos - carbon cloth & Contaminação do solo, água \\
\hline \multirow{2}{*}{ Remoção da Membrana Nafion@ } & Consumo de água & Depleção do recurso natural \\
\cline { 2 - 3 } & Resíduos - polímero & Contaminação do solo,água \\
\hline \multirow{2}{*}{ Aquecimento da solução } & Emissões gasosas de CO e $\mathrm{CO}_{2}$ & Contaminação do ar \\
\cline { 2 - 3 } & Consumo de Energiāa & Depleçầto de recursos naturais \\
\hline Remoção do soluto & Particulados de platina & Contaminação do ar \\
\hline
\end{tabular}

É possivel observar que o consumo de energia pode traduzir-se em potenciais impactos nos quais a visualização do dano decorre, principalmente, de uma cadeia de efeitos e não de uma conseqüência imediata do aspecto ambiental (isto não exclui a possibilidade de danos indiretos em relação aos outros mencionados). A FIG 6.21 ilustra um exemplo relacionado ao consumo de energia.

Aumento do consumo

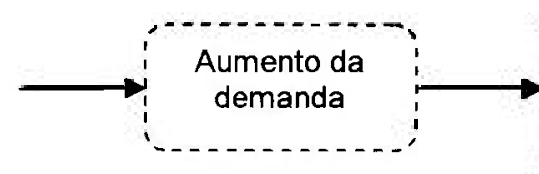

Aumento da capacidade de produção
Construção de novas hidroelétricas

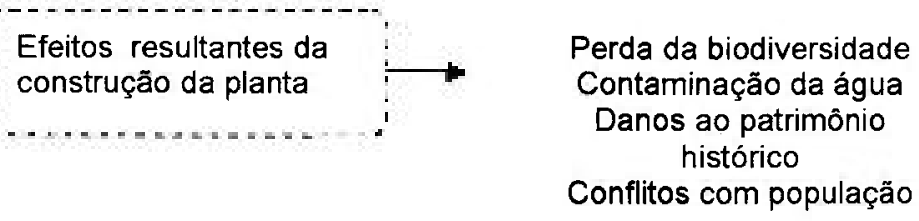

FIGURA 6. 21 - Exemplo de uma cadeia de efeitos relativos ao consumo de energia 
Claramente, esse exemplo não apresenta todas as alternativas de ocorrência mas, apenas ilustra uma possivel rede de conseqüências nas quais o uso de energia elétrica pode estar relacionado. De outra maneira, indica que a identificação de impactos não se limita à visualização imediata dos danos, porém da teia de relações que podem ser estabelecidas.

Quanto aos demais aspectos ambientais, a observação do efeito, aqui considerada é a direta, assim salienta-se que no consumo de água, o impacto decorrente advém do esgotamento de águas superficiais. Especialmente em São Paulo, a questão do abastecimento hídrico desponta como uma das questões amplamente em pauta na agenda pública, visto a escassez deste recurso.

Não obstante, também na escala local , a contaminação dos solos é foco de atenção no município. O diagnóstico de 500 áreas contaminadas na capital paulista (excluindo a região metropolitana) ${ }^{21}$, tem direcionado os esforços da agência ambiental do municipio (Companhia de Tecnologia de Saneamento Ambiental - CETESB) no sentido de equacionar o problema, o que resulta não só em ações de remediação como, em um maior monitoramento das atividades potencialmente poluidoras.

Segundo VALLE (1995), este evento ocorre usualmente pela disposição imprópria, de resíduos e produtos contaminados com agentes tóxicos ou perigosos, possibilitando que os reagentes neles contidos se difundam, por lixiviação ou solubilização, no meio físico. Conseqüentemente, propiciam a poluição de águas subterrâneas, danos ao patrimônio e àqueles relacionados à saúde humana pela ocupação residencial de tais locais, entre outros.

Já a contaminação do ar, até pouco tempo, essa questão era relegada e tratada como um tema pouco importante, visto que as chaminés e os carros eram vistas como símbolos de progresso (VALLE, 1995). No entanto, atualmente é evidente que este problema reflete, particularmente em áreas densamente povoadas, como a cidade de São Paulo, efeitos deletérios a saúde humana e inclusive ao ambiente natural e construído. Ainda, tais efeitos não se restringem à 
localidade de origem da fonte, como atingem escalas regionais e locais (cf. cap.1). Em função disto, na capital paulista, medidas para monitorar e controlar a qualidade do ar, se configuram, por exemplo, na fiscalização de fumaça preta e no rodízio de carros.

\subsubsection{Análise de Significância}

Diante do quadro apresentado, os potenciais impactos foram analisados quanto a sua significância em relação às escalas de probabilidade, severidade, limites e status regulatório (ver. cap 5). Os dados obtidos na nesta fase são apresentados na TAB 6.20.

TABELA 6.20 - Avaliação da significância dos impactos

\begin{tabular}{|c|c|c|c|c|c|c|}
\hline ASPECTO AMBIENTAL & POTENCIAL IMPACTO & 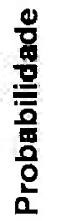 & 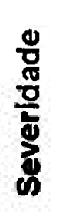 & & 旁 & 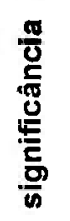 \\
\hline Particulados de platina & Contaminação do ar/água/solo & 5 & 3 & 5 & 5 & 375 \\
\hline Resíduos - carbon cloth & Contaminação do solo/água & 3 & 1 & 1 & $\overline{1}$ & 3 \\
\hline Consumo de água & Depleção do recurso natural & 3 & 4 & 4 & 5 & 360 \\
\hline Residuos - polímero & Contaminação do solo/água & 3 & 1 & 1 & 1 & 3 \\
\hline Emissões gasosas de $\mathrm{CO}$ e $\mathrm{CO}_{2}$ & Contaminação do ar & 5 & 5 & 5 & 5 & 625 \\
\hline Consumo de Energia & Depleção de recursos naturais & 5 & 5 & 4 & 5 & 500 \\
\hline
\end{tabular}

Nesta avaliação, para a pontuação dos potenciais impactos duas questões primordiais para esta análise foram consideradas, nas quais se configuram :

* Na necessidade de caracterizar os residuos gerados no processo segundo a norma ABNT NBR $10004(2004)^{22}$ - residuos inertes, não inertes e perigosos. Dada a limitação da amostragem não era possivel realizar os ensaios necessários. Assim, considerou-se as informações técnicas disponibilizadas pelos fabricantes; porém uma avaliação mais aprofundada quanto à legislação e os atuais meios de disposição final para estes materiais, em específico, são prementes.

\footnotetext{
${ }^{52}$ Associação Brasileira de Normas Técnicas - ABNT / NBR 10004 - Residuos Sólidos Classificação, 2004. $71 \mathrm{p}$.
} 
* Em divergências quanto ao critério do grau de severidade de todos os potenciais impactos. Observou-se que para tal escala, as questões levantadas no item anterior estão intimamente relacionadas e, referem-se às informações consolidadas quanto ao dano potencial de particulados de platina. Ademais, para a questão de energia relevou-se os dados apontados no capítulo 1. A TAB 6.21 apresenta estas considerações e outros critérios tomados na pontuação.

TABELA 6.21 - Critérios considerados durante a pontuação

\begin{tabular}{|c|c|c|c|c|c|}
\hline ASPECTO AMBIENTAL & POTENCIAL IMPACTO & PROBALIDADE & SEVERIDADE & LIMITES & STATUS REGULATÓRIO \\
\hline Partlculados de platina & Contaminaçăo do ar & $\begin{array}{c}\text { Dados levantados na } \\
\text { seçảo } 6.1 .4 \text { deste capítulo. }\end{array}$ & $\begin{array}{l}\text { Năo há registros } \\
\text { confirmados (1) }\end{array}$ & $\begin{array}{c}\text { Dados levantados na } \\
\text { seçăo 6.1.4 deste capítulo. }\end{array}$ & $\begin{array}{l}\text { Padroes de qualidade do } \\
\text { ar CONAMA 03/90 }\end{array}$ \\
\hline Residuos - Carbon Cloth & Contaminaçăo dọ soto & $\begin{array}{c}\text { Clas sificaçāo do residuo } \\
\text { segundo ABNT NBR } \\
10004\end{array}$ & $\begin{array}{c}\text { Classificaçāo do residuo } \\
\text { segundo ABNT NBR } \\
10004\end{array}$ & $\begin{array}{l}\text { Classificaçāo do residuo } \\
\text { segundo ABNT NBR } 10004\end{array}$ & $\begin{array}{c}\text { Classificaçāo do residuo } \\
\text { segundo ABNT NBR } \\
10004\end{array}$ \\
\hline Consumo de água & $\begin{array}{c}\text { Depleçāo do recurso } \\
\text { natural }\end{array}$ & $\begin{array}{c}\text { Representatividade do } \\
\text { processo (1) }\end{array}$ & $\begin{array}{l}\text { Abastecimento hidrico no } \\
\text { municipio de Sáo Paulo }\end{array}$ & $\begin{array}{l}\text { Abastecimento hidrico no } \\
\text { municipio de São Paulo }\end{array}$ & $\begin{array}{l}\text { Politica Nacional de } \\
\text { Recursos Hidnicos - Lei } \\
9433 \text { (2) }\end{array}$ \\
\hline Residuos - Polimero & Contaminação do solo & $\begin{array}{l}\text { Especificacooes tecricas da } \\
\text { DuPont(1) }\end{array}$ & $\begin{array}{c}\text { Classificaçăo do residuo } \\
\text { segundo ABNT NBR } \\
10004\end{array}$ & $\begin{array}{l}\text { Classificação do residua } \\
\text { segundo ABNT NBR } 10004\end{array}$ & $\begin{array}{c}\text { Classificação do residuo } \\
\text { segundo ABNT NBR } \\
10004\end{array}$ \\
\hline $\begin{array}{l}\text { Emissōes gasosas de } \mathrm{CO} \\
\text { e } \mathrm{CO}_{2}\end{array}$ & Contaminaçăo do ar & Dados do cap. 1 & $\begin{array}{c}\text { Qualidade do ar no } \\
\text { municipio de São Paulo }\end{array}$ & Dados do cap. 1 & $\begin{array}{l}\text { Padrōes de qualidade do } \\
\text { ar CONAMA 03/90 }\end{array}$ \\
\hline Consumo de energia & $\begin{array}{c}\text { Depleçä́o de recursos } \\
\text { naturais }\end{array}$ & Dados do cap 1 & $\begin{array}{l}\text { Produção de energia } \\
\text { hidroelétrica (construçăo) }\end{array}$ & $\begin{array}{l}\text { Produçăo de energia } \\
\text { hidroelétrica (construçăo) }\end{array}$ & $\begin{array}{l}\text { Politica Nacional de Meio } \\
\text { Ambiente LEI } 6938 \text { (3) }\end{array}$ \\
\hline (1) Optou-se pela esc & la intermediária, devido à & eficiència de informaçöes e & scala laboratorial do proce & sso. & \\
\hline Lel 9.433. Politica & acional de Recursos Fidr & os - cría o sistema Naclona & de Gerenciamento de Recu & rsos Hidricos, 1997. & \\
\hline (3) Lel 6938. Politica & clonal de Meio Ambiente & cria fins de mecanismos d & formulação e aplicaçäo, 1 & & \\
\hline
\end{tabular}

Mesmo diante destas considerações, uma grande contradição quanto à análise da importância de tais impactos é perceptível e se consolida no fato de que os resíduos gerados no processo não se traduzem na irrelevância de tal aspecto, pelo contrário implica que uma maior atenção deve ser dada já que não são conhecidos seus possiveis efeitos e conseqüências ao sistema de gerenciamento pós-uso da PEMFC.

Portanto, esta análise reflete o conhecimento limitado aos dados alcançados por este estudo e que só confirmam a significância de impactos ambientais já conhecidos, nos quais comumente são efetuadas ações mais cautelosas por diversas organizações produtivas, particularmente no que tange 
ao consumo de energia, devido a sua essencialidade no sistema de manufatura $e$, quanto às emissões, por se constituírem também em questões globais.

Neste panorama, deve-se atentar para a escolha de métodos de avaliação e qualificação dos impactos a fim de evitar contradições quanto à significância destes, embora isto também esteja relacionada à subjetividade dos critérios utilizados. Não obstante, nesse estudo as limitações dadas pela amostragem e suas implicações influenciaram para a contradição aqui apresentada.

Destarte, por outro lado, pode-se observar que a avaliação ambiental do ciclo de vida evidencia informações (por exemplo, problemas ambientais locais) que devem ser levadas em consideração no processo decisório (juntamente com outras de caráter técnico e legal) para o futuro aprimoramento do método de recuperação dos catalisadores de platina da PEMFC e consolidação da tecnologia. 
Nesta dissertação procurou-se sintetizar e sistematizar as inúmeras informações sobre a análise ambiental da PEMFC. Muitos aspectos técnicos foram bastante simplificados para não perder a visão de conjunto que se pretendia dar; esses podem ser aprofundados nas referências apresentadas no decorrer e final deste trabalho.

Da mesma forma, neste capítulo as conclusões são tratadas com brevidade, uma vez que em cada fase deste estudo se procurou finalizar as questões levantadas $e$, incluir as recomendações e sugestões de trabalhos futuros. Não obstante, considerando os resultados obtidos, alguns pontos tornamse claramente necessários reafirmar, são eles:

A tecnologia PEMFC apresenta diversas vantagens, as quais a configuram em uma candidata ideal para o futuro sistema energético. Contudo, as informações sobre a platina evidenciam a indissociabilidade das questões ambientais às econômicas, uma vez que a disposição do recurso na natureza é limitada, sua exploração envolve impactos de grande escala e a demanda por esta matéria prima é ampla.

Por conseguinte, a reciclagem primária deste metal torna-se mandatária para a sustentabilidade da PEMFC, visto que melhorias no processo para evitar os desperdícios por si não são suficientes. De outra forma, a reciclagem pode se tornar um negócio lucrativo, uma vez que a demanda para a indústria automobilistica tem aumentado ano após ano, paralelamente ao aumento do preço da matéria prima e, a tendência de padrões mais rígidos de controle ambiental.

Neste quadro, os investimentos para o desenvolvimento de um processo de reciclagem dos catalisadores de platina da PEMFC se justificam de diversas formas, dentre elas destacam-se: a possibilidade de inovação tecnológica, já que muitos programas de $P \& D$, especialmente internacionais, tem trabalhado nesta direção mas, ainda sem sucesso e, os métodos existentes não são adequados e específicos para tal material. 
Ainda, a avaliação do ciclo de vida tem se consolidado como uma importante ferramenta de gestão empresarial capaz de avaliar os riscos e oportunidades que acompanham um determinado produto. Seu uso e importância têm se manifestado pela crescente exigência da sociedade quanto às declarações de performance ambiental de produtos ou serviços, além de aspectos relacionados à competitividade.

No entanto, a gama de informações necessárias e os fatores relacionados à coleta, tratamento e análise dos dados, além de outras atividades correlatas e afins, demanda uma grande quantidade de tempo e um enorme esforço para alcançar resultados plausíveis. Neste caso, a criação de um inventário apropriado para as condições próprias do país, o uso do software e capacitação para aplicação pode vir a sanar tais problemas.

Os recortes no horizonte de análise do processo de recuperação dos catalisadores refletem as incertezas quanto aos aspectos de produção e destinação final da PEMFC dada a sua "infância", além de traduzirem a complexidade da ACV e dos fatores a ela inerentes. Ainda, a determinação do potencial de reciclagem envolve o futuro aprimoramento do processo de recuperação desenvolvido no IPEN, para remover as variáveis relacionadas ao estudo exploratório $\mathrm{e}$ as que interferem a atividade catalítica do material recuperado.

Conseqüentemente, as informações apresentadas na $\mathrm{ACV}$ do processo constituem-se em um passo inicial na direção de rotas alternativas que visem minimizar os impactos ambientais e econômicos relacionados a esse metal no ciclo de vida da PEMFC, e que por fim, configuraram úteis para verificar, mesmo parcialmente, as entradas e saidas do processo e, a medida de eficiência.

Ademais, deve-se atentar para a escolha de métodos de avaliação e qualificação dos impactos a fim de evitar contradições quanto à significância destes. Não obstante, ressalta-se que a avaliação ambiental do ciclo de vida evidencia informações a serem consideradas no processo decisório (juntamente com outras de caráter técnico e legal) em especial, para o futuro aprimoramento do processo e consolidação da tecnologia PEMFC. 
Neste panorama, pode se concluir que os objetivos estabelecidos neste trabalho foram atendidos, inclusive no que se refere às exigências do propósito $e$ escopo do estudo da ACV. Portanto, o desenvolvimento do processo de recuperação e posterior método de reciclagem da platina da PEMFC, deve ocorrer concomitante a Avaliação do Ciclo de Vida, uma vez que tal instrumento fornece a visão necessária para subsidiar as estratégias de desenvolvimento e inovação da tecnologia. 
ALDABÒ. R. Célula combustivel a hidrogênio fonte de energia da nova era / Ricardo Aldabó - São Paulo: Artiber Editora: 2004.p.179.

ASSOCIAÇÃO BRASILEIRA DE NORMAS TÉCNICAS. NBR ISO 14001 Sistemas de gestão ambiental - Especificação e diretrizes para uso. Rio de Janeiro: ABNT. 1996.

ASSOCIAÇÃO BRASILEIRA DE NORMAS TÉCNICAS. NBR ISO 14.040 Gestão ambiental - Avaliação do ciclo de vida: Princípios e estrutura. Rio de Janeiro: ABNT, 2001.

ASSOCIAÇÃO BRASILEIRA DE NORMAS TÉCNICAS. NBR ISO 14.041 Gestão ambiental - Avaliação do ciclo de vida: Definição de Objetivo e Escopo e Análise do Inventário. Rio de Janeiro: ABNT, 2004.

ASSOCIAÇÃO BRASILEIRA DE NORMAS TÉCNICAS. NBR ISO 14.042 Gestão ambiental - Avaliação do ciclo de vida : Avaliação do impacto do ciclo de vida. Rio de Janeiro: ABNT, 2004.

BALDO, W. R. Desenvolvimento de um Método de Preparação de conjuntos Eletrodo - Membrana - Eletrodo para Células a Combustivel a Membrana Trocadora de Prótons (PEMFC). Dissertação (Mestrado em Ciências na Área de Tecnologia Nuclear - Materiais). Instituto de Pesquisas Energéticas e Nucleares. Autarquia associada à Universidade de São Paulo. São Paulo. 2003. $71 \mathrm{p}$.

BAREFOOT, R. R. Speciation of platinum compounds: A review of recent applications in studies of platinum anticancer drugs. Environ Sci Technol 31, 2001. p. 835-844.

BAUEN, A. et. al. Fuel Cells for distributed generation in developing countries - an analysis. International Association for Hydrogen Energy. Elsevier Science Ltda. 2003. p. $695-701$. 
Brasil $\mathrm{H}_{2}$ Fuel Cell Energy. Disponivel em http:/l www.brasilh2.com.br. Acesso em dezembro de 2005.

BLOCK, M. R. Identifying Environmental Aspects and Impacts. United State: Quality Press, 1999. p.145.

CALDEIRA - PIRES, A. et.al. (org). Avaliação do Ciclo de Vida: a ISo 14040 na América Latina. - Brasilia: Abipit, 2005. 337 p.;21,5 cm.

CARVALHO, C. E. A Análise do Ciclo de Vida e os Custos completos no Planejamento Energético. Dissertação (Mestrado em Engenharia). Escola Politécnica da Universidade de São Paulo. São Paulo. 2000. 228p.

CARLSON, E. J. Precious Metal Availability and Cost Analysis for PEMFC Commercialization. Department of Energy. Hydrogen, Fuel Cells, and Infrastructure Technologies. Progress Report, 2003.

CHEHEBE, J. R. Análise do Ciclo de Vida de Produtos: ferramenta gerencial da ISO 14000. Rio de Janeiro: Editora Qualitymark. CNI, 1997. 120p.

CHRISTIANSEN, K. Life Cycle Assessment in a Historical Perspective, In: Workshop Internacional sobre Análise do Ciclo de Vida. Rio de Janeiro: ABNT, 1997.

COTTON, W., and PIELKE, R. Human impacts on weather and climate, Cambridge University Press, New York, 1996

CONSELHO NACIONAL DO MEIO AMBIENTE-CONAMA. Resolução 03 de 1990. Dispõe sobre o Padrão da Qualidade do Ar.

CURRAN, M.A. (org.). Environmental Life Cycle Assessment. Nova lorque: McGraw Hill, 1996.

CZERCZAK, S. \& GROMIEC, J.P. in Patty's Toxicology. 5 th ed.2001. 
DE BEAUFORT, LANGEVELD., et. al., 1997. Simplifying LCA: just a cut? Final report of the STAC Europe Screening and Streamlining Working Group, SETAC. Amsterdam. The Netherlands.

DEPARTMENT FOR TRANSPORT. Platinum and hydrogen for fuel cell vehicles.http://www.dft.gov.uk/stellent/groups/dft_roads/documents/page/dft_road s_024056-01.hcsp. Acesso em: outubro de 2004.

ELECTROCELL. Disponivel em http:// www. electrocell.com.br. Acesso em setembro de 2006.

FERNANDES, G. E. F. F., et. al. O Equilibrio entre a oferta e o consumo de Energia Elétrica: Tendências e Desafios. Disponivel em : polo01.feg.unesp.br/revistadigital/volume_especial/vol_esp-trabalhos. Acesso em dezembro de 2005.

FREY, TH. \& LINARDI, M. Effects of membrane electrode assembly preparation on the polymer electrolyte membrane fuel cell performance. Electrochimica Acta 50, 2004. p. $99-105$.

GRIMONI, J. A. B et.al. (org). Iniciação a Conceitos de Sistemas Energéticos para o Desenvolvimento Limpo.- São Paulo: Editora da Universidade de São Paulo, 2004. 306p.

GROT, S. Platinum Group Metal Recycling Technology Development. Hydrogen Program. Department of Energy Progress Report, 2003.

GROT, S. et.al. Platinum Recycling Technology Development. Hydrogen Program. Department of Energy. Progress Report, 2004.

HAILES, R. Fuel cells for transportation: An inventory analysis of environmental interventions associated with a prototype stack component manufacturing route. MSc. Thesis, Imperial College. 1999. 
HANDLEY, C. et. al. Impact of the European Union vehicle waste directive on end-of-life options for polymer electrolyte fuel cells. Journal of Power Sources. Elsevier Science Ltda. 2002. p. 344 - 352.

HAZARDOUS SUBSTANCES DATA BANK.. Data Bank National Library of Medicine's Toxnet system. Disponivel em: http:// toxnet.nlm.nih.gov. Acesso em : $18 / 04 / 2006$.

HART, D \& BAUEN, A, Further assessment of the environmental characteristics of fuel cells and competing technologies. ESTU Report F/02/00153/REP/1 Harwell, UK. 1998.

HART, D \& HORMANDINGER, G. Initial assessment of the environmental characteristics of fuel cells and competing technologies. Volume 1. ESTU Report F/O2/00111/REP/1 Harwell, UK. 1997.

HART, D \& HORMANDINGER, G. Environmental benefits of transport and stationary fuel cells. Power Sources, vol. 71, 1998. p.348-353.

HUNT, R. G., et.al., 1998. Case studies examining LCA streamlining techniques. Int. J. Life Cycle Assess. 3, pp. 36-42.

INSTITUTO BRASILEIRO DE INFORMAÇÃO EM CIÊNCIA E TECNOLOGIA. SEMINÁRIO IMPACTO DA AVALIAÇÃO DE CICLO DE VIDA PARA A COMPETITIVIDADE DA INDÚSTRIA BRASILEIRA. Realizado nos dias 03 e 04 de outubro de 2005. Blue Tree Convention Ibirapuera. São Paulo.

INTERNATIONAL ORGANIZATION FOR STANDARDIZATION. Environmental management - Life Cycle assessment: Principles and framework - ISO 14.040. Genebra: ISO, 1997.

INTERNATIONAL ORGANIZATION FOR STANDARDIZATION. Environmental management - Life Cycle Assessment: Goal and scope definition and inventory analysis- ISO 14.041. Genebra: ISO, 1998. 
INTERNATIONAL ORGANIZATION FOR STANDARDIZATION. Environmental management - Life Cycle Assessment - Life cycle: impact assessment- ISO 14.042. Genebra: ISO, 2000a.

INTERNATIONAL ORGANIZATION FOR STANDARDIZATION. Environmental management - Life Cycle Assessment: Life cycle interpretation - ISO 14.043. Genebra: ISO, 2000b

INTERNATIONAL ORGANIZATION FOR STANDARDIZATION. Environmental management- Life Cycle Impact Assessment: Examples of application of ISO 14.042- ISO/ TR 14.047. Genebra: ISO, 2003.

INTERNATIONAL ORGANIZATION FOR STANDARDIZATION. Environmental management - Life Cycle Assessment: Data documentation format- ISO/ TS 14.048. Genebra: ISO, 2002.

INTERNATIONAL ORGANIZATION FOR STANDARDIZATION. Environmental management - Life Cycle Assessment: Examples of application of ISO 14041 to goal and scope definition and inventory analysisISO/ TR 14.049. Genebra: ISO, 2000c.

JANUZZI, G.M. Energia e Mudanças Climáticas: barreiras e oportunidades para o Brasil. Disponivel em http://www.fem. unicamp.br/ jannuzzi/Artigos/id5.htm. Acesso em 10/05/2004.

KARAKOUSSIS et.al. Environmental Emissions of SOFC and SPFC System Manufacture and Disposal. Imperial College of Science, Technology and Medicine. London, 2000. 88 p.

KORDESCH, K \& SIMADER, G. Fuel cells and their applications. Weinheim : New York; Basel; Cambridge: Tokyo: VCH, 1996. ISBN 3-527-285792. NE: Simader, Gunter. p. 375. 
LYONS, K. S. et al. Low-Platinum Catalysts for Oxygen Reduction at Proton Exchange Membrane Fuel Cell Cathodes. Department of Energy. Hydrogen, Fuel Cells, and Infrastructure Technologies. Progress Report, 2003.

LASCHKA, D \& NACHTWEY, $M$. Platinum in municipal sewage treatment plants. Chemosphere $34(8), 1997$. p. 1802-1814.

LUNA, A. M. C. et. al. Eletrochem. Commun 2, 2000. p.222.

MATHEY, J. Platinum Today. Disponivel em: http.platinum.mathey.com/analygst_index. html. Acesso em 20/03/2006.

MATHEY, J. Platinum 2005 Interim Review. Inglaterra. 2005.

MINISTÉRIO DA CIÊNCIA E TECNOLOGIA. Fundo Setorial de Energia. Secretaria Técnica. Programa Brasileiro de Células a Combustivel: proposta para o programa. Brasília, DF: Centro de Gestão e Estudos Estratégicos CGEE, 2002. 30f.

MERCEDES BENZ. Necar. Disponivel em: www.mercedes-benz.com. Acesso em 02/04/2006.

NAGATA, N. et. al. Mathematical methods to correct spectral interferences and interelemental effects in $\mathrm{X}$-ray fluorescence quantitative analysis. Quím. Nova., São Paulo, v. 24, n. 4, 2001.

NATIONAL RENEWABLE ENERGY LABORATORY. Coast Analysis of PEM Fuel Cell Systems for transportation. September 30, 2005. Subcontract Report NREL/SR 560-39104. Carlson, E. J. et. al. Cambridge: Massachusetts, 2005. 99.p.

NETO, E. H.G. Hidrogênio Evoluir Sem Poluir: A era do hidrogênio, das energias renováveis e das células a combustivel. - Curitiba : BRASIL HE FUEL CELL ENERGY, 2005. p. 240. 
NETO, A O. Comunicação pessoal. Instituto de Pesquisas Energéticas e Nucleares/ IPEN, Centro de Ciência e Tecnologia de Materiais - CCTM Laboratório de Células a Combustivel, 2006.

OLIVEIRA, C. T. de A et. al . A Evolução da Importância Ambiental. In: GRIMONI, J. A. B et.al. (org). Iniciação a Conceitos de Sistemas Energéticos para o Desenvolvimento Limpo.- São Paulo: Editora da Universidade de São Paulo, 2004. p. 39-66.

OKOINSTITUTE. A Balance of Ecological Impact's from the Extraction / Production of PGM for Passenger Car Autocatalyses. 1997.

PEHNT, M. Ganzheitliche Bilanzierung von Brennstozellen als zukunftigen Energiesystemen (Life cycle assessment of fuel cells as future energy systems). Dissertation, German Aerospace Center. Institut fur Technische Thermodynamik, Stuttgart, 2000a.

PEHNT, M. Life Cycle Analysis of Fuel Cells and Relevant Fuel Chains. Proceedings Hyforum, 2000b. S. 387 -396. Munchen, September 2000.

PEHNT, M. Life-cycle Assessment of Fuel Cell Stacks. International Association for Hydrogen Energy. Elsevier Science Ltda, 2001. p. 91 - 101.

PEHNT. M. Life Cycle Assessment of Fuel Cells in Stationary and Mobile Applications, Dissertation, VDI- Verlag, Düsseldorf, 2002, ISBN 3-18347606-1.

PEHNT, M. Life Cycle Analysis of Fuel Cell System Components. Handbook of Fuel Cells - Fundamentals, Technology and Applications, edited by Viestich, W. et. al. Volume 4. 2003 
PEHNT, M. \& RAMESOHI, S. Fuel cells for distributed power: benefits, barriers and perspectives. Commissioned by WWF in co-operation with Fuel Cell Europe. June 2002. Disponivel em http:// www.etn.wsr.ac.at. Acessado em $17 / 05 / 2004$.

PEREZ, J., GONZALEZ, E.R. TICIANELLI, E.A. Oxygen Electrocatalysis on thin porous coating rotating platinum electrodes. Electrochim Acta, Lausanne, Switzerland, v.44, 1329, 1998.

PENNA,C.G. O Estado do Planeta: sociedade do consumo e degradação ambiental. Rio de Janeiro: Record, 1999. 252 p.

PENÃ, C. et. al. Mineria, Metales y Análises del Ciclo de Vida: Nuestra Experiencia en Chile. In: CALDEIRA, A. P. et.al. (org). Avaliação do Ciclo de Vida: a Iso 14040 na América Latina. - Brasilia: Abipit, 2005. p. 205-217.

POWER PULSE. Disponivel em http:// www.powerpulse.net. Acesso em maio de 2006.

RALF, T. R. Proton Exchange Membrane Fuel Cells: progress in cost reduction of key components. Platinum Metals Rev., 1997,41, (3). p. 102-113.

REIS, L. B. \& SILVEIRA. S. Energia Elétrica para o Desenvolvimento Sustentável. 2 ed. - São Paulo: Editora da Universidade de São Paulo, 2001.

REIS, L. B. et. al. Energia, Recursos Naturais e a Prática do Desenvolvimento Sustentável. - Barueri, São Paulo: Manole, 2005. 415 p.

REBITZER, G. et. al. Life cycle assessment. Part 1: Framework, goal and scope definition, inventory analysis, and applications. Environment International Science Elsevier Ltda, 2004. p. 701-720.

RENNER, H. \& SCHMUCKLER, G. pp. 1135-51 in Metals and their Compounds in the Environment. 1991. 
ROBERTSON, A. B. Platinum Group Metal Recycling Technology Development. Hydrogen Program. Department of Energy. Progress Report, 2003.

SALGADO, J. R. C \& GONZALEZ, E. R. Correlação entre a atividade catalitica e o tamanho de particulas de $\mathrm{Pt} / \mathrm{C}$ preparados por diferentes métodos. Eclética Química., São Paulo, 28 (2): 77-86, 2003.

SILVA, L.M. L., et. al. Análise preliminar da viabilidade técnica da utilização do pó de micaxisto dosado ao solo como material de pavimentação viária urbana. In: CONGRESSO DE PESQUISA, ENSINO E EXTENSÃO DA UFGCONPEEX, 2., 2005, Goiânia. Anais eletrônicos do XIII Seminário de Iniciação Cientifica [CD-ROM], Goiânia: UFG, 2005. n.p.

SILVEIRA, S. et. al. A Energia Elétrica no Âmbito do Desenvolvimento Sustentável. In: REIS, L. B. \& SILVEIRA. S. Energia Elétrica para o Desenvolvimento Sustentável. 2 ed. - São Paulo: Editora da Universidade de São Paulo, 2001. p. 17-42.

SHORE, L. \& ROBERTSON, B. Platinum Group Metal Recycling Technology Development. Hydrogen Program. Department of Energy. Progress Report, 2004.

SPINACÉ, E. Comunicação pessoal. Instituto de Pesquisas Energéticas e Nucleares/ IPEN, Centro de Ciência e Tecnologia de Materiais CCTM, Laboratório de Células a Combustivel, 2006.

STARZ, K.A. , AUER, E., LEHMANN, Th, ZUBER, R. Characteristics of platinum based eletrocatalysts for mobile PEMFC aplications. Journal Power Sources, Hanan, Germany, v. 84, p. 167-172,1999. 
SUPPEN, N. \& ABITIA, A. R. Evoluación Del Impacto Del Ciclo de Vida: Elementos de Guía Y Algumas Consideraciones Metodológicas para México. In: CALDEIRA, A. P. et.al. (org). Avaliação do Ciclo de Vida: a Iso 14040 na América Latina. - Brasília: Abipit, 2005. p. 89-118.

TOSTA, C. S \& KIPERSTOK, A. Inserção da Análise de Ciclo de Vida no Estado da Bahial Brasil através da atuação do Órgão Ambiental. In: Avaliação do Ciclo de Vida: A ISO14040 na América Latina - Brasilia: Abipit, 2005. p.118-131.

TILLMAN, A.M. \& BAUMANN, H. General Description of Life Cycle Assessment Methodology. Estocolmo: Chalmers University of Technology, 1995.

UDAETA, M. E. M. et al. Aspectos Relevantes acerca do Desenvolvimento. In: GRIMONI, J. A. B et.al. (org). Iniciação a Conceitos de Sistemas Energéticos para o Desenvolvimento Limpo.- São Paulo: Editora da Universidade de São Paulo, 2004. p.19-25.

UNIDET NATIONS ENVIROMENT PROGRAME - UNEPI SETAC. Life Cycle Approaches. The road from analysis to practice. Division of Technology, Industry and Economics (DTIE). Production and Consumption Unit. Paris: France. p. 89.

VALLE, C. E do. Qualidade Ambiental: como ser competitivo protegendo o meio ambiente - como se preparar para as normas ISO 14000. São Paulo: Pioneira, 1995. $117 p$

VIGON, B.W. et al. Life Cycle Assessment: Inventory Guidelines and Principles. Cincinnati: EPA, 1993.

$\mathrm{XIAO}$ et. al. Sequent and accumulative life cycle assessment of materials and products. Materials and Design, vol.22. 2001. p.147-149. 
ZEIRINI, F. et. al. Environ Sci Technol. 35: 1996-2000. 2001

WENDT, H. et. al. Tecnologia de Células a Combustível. Química Nova. Vol. $23, n^{\circ} 4$. 2000. p. $538-546$.

WENDT, $H$. et. al. Células a Combustivel de Baixa Potência para Aplicações Estacionárias. Química Nova, vol. 25, n³. 2002. p. 470 - 476.

WHO. Environmental Health Criteria, Platinum. Geneva, Switzerland: Who 125: 1-167. 1991. 